\title{
Labor and the Corporate Structure: Changing Conceptions and Emerging Possibilities*
}

\author{
Katherine Van Wezel Stone $\dagger$
}

\section{INTRODUCTION}

There is a paradox in the current world of labor relations. On the one hand, unions are becoming increasingly dissatisfied with the operation of the National Labor Relations Act ("NLRA") and union strength is on the decline. ${ }^{2}$ Yet on the other hand, some unions are playing new roles in corporate life and have found ways to exercise unprecedented power in corporate decision making. Unions and their lawyers are developing ways to exert pressure on corporate decisions outside the conventional labor law framework. Sometimes by desire, and sometimes by necessity, unions find themselves participating in corporate management in order to protect their members from those types of investment decisions over which conventional labor law denies them input.

In 1974, Leonard Woodcock, then President of the United Auto Workers, prophesised that workers in the coming decades would have to exert pressure for joint decision making in matters like plant closings, relocations, subcontracting and price, product and investment decisions, "out of a pragmatic interest in protecting themselves and their families from the multiple insecurities and inequities the current governance of [corporations] permits."3

* Copyright 1988 by Katherine Van Wezel Stone.

$\dagger$ Associate Professor of Law, Benjamin N. Cardozo Law School, Yeshiva University. I would like to thank the many colleagues and friends who gave generously of their time and ideas in reviewing this manuscript. In particular, I owe special thanks to William Bratton, David Carlson, Morton Horwitz, Duncan Kennedy, Robin Kowal Kern, Lewis Kornhauser, Howard Lesnick, Joseph McCahery, Gary Peller, Monroe Price, William Simon, and Dave Van Zandt. Charles King provided exceptional research assistance. Errors, of course, are mine alone.

129 U.S.C. $\S \S 151-169$ (1982).

2 Unionized workers comprised 28.9 percent of the nonagricultural workforce in 1975. That percentage had fallen to 21.9 percent by 1982. Statistical Abstract of the United States 1987 (Table No. 692) 408.

- Leonard Woodcock, USA, in Charles Levinson, ed., Industry's Democratic Revolution 199, 215-216 (1974). See also, Robert J. Rabin, Fibreboard and the Termination of Bargaining Unit Work, 71 Colum.L.Rev. 803, 836 (1971) (Unions are increasingly interested in 
This prediction has come to pass. ${ }^{4}$ In recent years, industrial disinvestment and corporate transformations have led to massive and highly visible dislocations throughout major sectors of the economy..$^{5}$ Many of these dislocations have occurred in industrial manufacturing, a sector of the economy which has been heavily unionized for the past fifty or more years. ${ }^{6}$

At the same time that corporate investment decisions are causing massive lay-offs throughout the unionized sectors, the labor laws are being reinterpreted to give unions less and less input into corporate decision making." The consequences are serious. First, unions are unable to protect the employment opportunities of their members, so that over time their strength erodes as those plants and companies that are unionized change their structure, location, owners, and so forth. In industries which are heavily unionized, unions cannot protect against diversification-shifts of

achieving protection against the hazards of economic dislocations).

- In 1983, Anthony Mazzocchi, former Vice President of the Oil, Chemical, and Atomic Workers International Union, said:

At some point the labor movement will have to take a stand. We will have to develop a coherent program which deals with the mobility of capital, . . . and which calls for an end to management rights as we know them. We have to take the stand that working people in their organizations must have a very direct say in corporate investments, and that the right to manage and move capital wherever they please can no longer be left to multinational corporations.

Changing Economic Realities and the Changing Role of Unions, 11 N.Y.U. Rev. of L. \& Soc. Change 7, 10 (1983).

See also, William B. Gould IV, The Burger Court and Labor Law, 24 San Diego L.Rev. 51,61 (1987) ("With the advent of concession bargaining in the late 70's and 80's and increased union setbacks, the focus of the labor movement has become job security"); James B. Atleson, Reflections on Labor, Power and Society, 44 Md.L.Rev. 841, 842-43 (1985) (increase in capital mobility and changes in corporate structure have had an impact on viability of collective bargaining).

s Barry Bluestone and Bennett Harrison, The Grim Truth About the Job 'Miracle', Study for Joint Economic Committee, summarized in New York Times sec. 3, p. 3, col. 1 (February 1, 1987) (workers displaced by plant shutdowns since 1979 unlikely to find another well paying and stable job); Ronald J. D'Amico and Jeff Golon, The Displaced Worker, in Stephen M. Hills, ed., The Changing Labor Market: A Longitudinal Study of Young Men 32-3 (1986) (young workers displaced by plant shutdowns lose on average 7.85 per cent of their income, as well as their fringe benefits, pensions, seniority, and job specific skills).

6 Barry Bluestone and Bennett Harrison, The Deindustrialization of America 25-48 (1982); Peter E. Millspaugh, Plant Closings and the Prospects for a Judicial Response, 8 J.Corp.L. 483, 483 (1983) (plant closings occur as economy shifts away from industrial production). See also Paul D. Flaim and Ellen Sehgal, Displaced Workers of 1979-83: How Well Have They Fared?, 108 Monthly Labor Review 6:3, 3 (June 1985) (of 5.1 million workers with three or more years experience displaced between 1979 and 1984, only 3.1 million were employed in January, 1984, and one-half of those were earning less than they had on their previous job.

See Part II. 
capital to other industries with higher profit rates. In industries that are only partially unionized, they cannot protect members' jobs because bargaining for higher wages or better conditions puts unionized employers at a competitive disadvantage. And in no industry can a union protect its members from foreign competition. These limitations mean that unions are losing their appeal to unorganized workers because, as employers now stress in their antiunion campaigns, unions cannot guarantee that workers will have a job. ${ }^{8}$

Many voices within the union movement have expressed frustration with current labor law. ${ }^{\ominus}$ Owen Bieber, President of the United Auto Workers, claims that Reagan administration policies of deindustrialization have led to a decline in UAW membership of one-third from 1979 to 1986, and that the "NLRB has turned its back and even acted to make matters worse."10 Similarly, Anthony Mazzocchi, former Vice President of the Oil, Chemical, and Atomic Workers Union, says:

Based on my own experiences, the labor movement as it's now constituted, can't deliver . . . . [W] can't deal with corporate America. The sides are uneven and they're going to beat us to the ground . . . . We've got to deal with mobility of capital. We've got to deal with investment decisions. ${ }^{11}$

As Woodcock predicted, in the last five years unions have begun to deal with corporate investment decisions by demanding participation in the making of them. Union participation in the corporate structure takes many different forms. For example, unions in the airline industry have taken a leading role in many corporate reorganizations and takeover battles by actively seeking out

B A recent study of the causes of the decline in union membership found that increasingly, unorganized workers believe that unions cannot help with important areas of job concern. A Recent Decline in Unionization in the United States, 238 Science 915, 919 (November 13,1987$)$.

- For example, AFL-CIO President Lane Kirkland has advocated that the N.L.R.A. be repealed because it is no longer serving labor's cause. AFL-CIO Chief Calls Labor Law a Dead Letter, Wall St.J. 8, col.2 (Aug. 16, 1984). Similarly, John J. Sweeney, President of the Service Employees International Union, AFL-CIO, recently said, in a speech delivered to a Fordham Law School symposium on labor law: "[M]y answer to the question whether the National Labor Relations Act should be amended is simple: No! The National Labor Relations Act . . . is, for all practical purposes, now dead. . " 52 Fordham L.Rev. 1142, 1143 (1984).

10 Owen Bieber, For American Workers American Government is Not Working Well at All, 15 Cap.U.L.Rev. 475, 476, 478 (1986).

11 Mazzocchi, 11 N.Y.U.Rev. of L. \& Soc. Change at 25 (cited in note 4). 
white knights, ${ }^{12}$ and by negotiating special contingent labor agreements with some of the contenders in control battles, in order to affect the outcomes. ${ }^{13}$ One union even negotiated a "poison pill" to ward off a takeover by another union. ${ }^{14}$

In another forum, unions have discovered that they can, and must, participate in bankruptcy proceedings under Chapter 11 in order to protect the interests of their members and of the pension plans they have negotiated. ${ }^{16}$ Thus, in a Chapter 11 reorganization, they have learned how to obtain appointments to committees of unsecured creditors and how to exercise considerable leverage on those committees, in their dealings both with other unsecured creditors and with the secured creditors. ${ }^{16}$ In the process, unions negotiate with lenders, other creditors, management, and shareholders about how to restructure the enterprise, and on what terms a reorganization plan will have labor support. In short, unions are defending traditional labor concerns in the bankruptcy

12 See, e.g., Pan Am and the Rise of Union Power, New York Times D1 (January 25, 1988) (describing role of unions in ousting five top officers of Pan American Airlines); Friendly Guy, Unfriendly Skies, Fortune 122 (September 14, 1987) (Airline Pilots Association formed company to take over United Airlines and hired Piedmont Airlines' chief executive officer to head its effort); People Express Wins the Duel for Frontier Air, Business Week 42 (October 21, 1985) (describing efforts of Frontier Airlines to find a "white knight" to avoid takeover effort); Labor Takes a Chair in the Board Room, New York Times E4, col.3 (March 9, 1986) (unions in the airline industry try to attract investors for troubled companies).

${ }^{13}$ See, e.g., The TWA Deal: Will Labor Deliver For Icahn? Business Week 36 (August 19, 1986) (TWA unions offer Icahn large concessions to avoid takeover); Frontier's Unions Circle Wagons Against Lorenzo, Business Week 34 (October 7, 1985) (labor efforts to arrange a buyout of airlines to avoid takeover); Frontier Files for Bankruptcy, New York Times DI, col. 6 (August 29, 1986) (Frontier files for bankruptcy because potential purchase by United airlines fell apart when United pilots union refused to agree to adequate concessions).

14 Labor Pact Could Foil United Bids, New York Times, Sec. D., p. 1 (November 11, 1987).

15 See, e.g., Jones \& Laughlin Hourly Pension Plan v. LTV Corp., 824 F.2d 197 (2d Cir. 1987); Local 144 Hospital Welfare Fund v. Baptist Medical Center of New York, Inc., 781 F.2d 973 (2d Cir. 1986). See also Republic Airlines: One Union Down and Five To Go, Business Week 33 (April 9, 1984) (efforts of Republic's pilots to obtain deferred wages in the form of liquidating preferred stock to protect themselves in the event of a bankruptcy).

${ }^{26}$ On unions' right to sit on a creditors' committee in a Chapter 11 proceeding, see Matter of Enduro Stainless Inc., 59 Bankr. 603 (Bkrtcy.N.D.Ohio 1986); In re Altair Airlines, Inc., 727 F.2d 88 (3rd Cir. 1984). For a detailed discussion of labor's rights to obtain representation on creditor committees, and of procedures and strategies available to unions on creditors committees, see Leon C. Marcus, Marc E. Richards, and Cindy S. Korman, Labor Representation of the Committee of Unsecured Creditors, unpublished paper prepared for the AFL-CIO Lawyer Conference, April 28, 1983 (on file at the University of Chicago Law Review). 
proceeding. ${ }^{17}$

Similarly, in some troubled industries, in order to avoid a bankruptcy filing, major lenders insist on labor concessions as the quid pro quo for debt restructuring. When this happens, unions are involved in creditor work-outs, either by meeting with the creditors or by communicating with them via the intermediary of management. ${ }^{18}$ Similarly, as part of their efforts to protect their collateral, major creditors sometimes insist on participating in collective bargaining sessions in order to influence the labor contracts. When this occurs, they become de facto parties to the negotiations, and unions, either directly or indirectly, negotiate as much with the creditors as with management. ${ }^{19}$

Another emerging form of labor participation in the corporate structure is the increased frequency with which unions negotiate for representation on corporate boards of directors, usually in exchange for concessions in collective bargaining. ${ }^{20}$ In recent years, unions have negotiated for board representation of major companies in the automobile, airline, trucking, and food processing industries. ${ }^{21}$ In addition to formal board representation, many unions have negotiated for representation on special advisory committees which have access to financial information and which have a regular right to meet with the board to discuss investment strategies. ${ }^{22}$

\footnotetext{
${ }^{17}$ See, e.g., Frank Lorenzo's Mission Is Nearly Accomplished, Business Week 109 (September 16, 1985) (efforts of Continental Airlines to gain court approval of its reorganization plan and to separate claims of its union creditors from those of all other creditors). See also Wheeling-Pittsburgh Steel Corp. v. United Steelworkers of America, 791 F.2d 1074, 10931094 (3rd Cir. 1986) (duty of company to bargain with union after filing of Chapter 11 petition).

${ }^{18}$ Alex Gibney, Paradise Tossed-How a Chance to Save American Capitalism Was Sabotaged at Eastern, 18 Washington Monthly 24, 27 (1986) (describing how a union president and a company's bankers "hashed out" the terms of the 1983 collective bargaining agreement).

10 See, A Union Deal Pulls Eastern Back From Default, Business Week 32 (February 25,1985 ) (creditors of Eastern Airline stepped into the union negotiations in order to extract concessions).

${ }^{20}$ See, e.g., Lynn Williams, Expanding the Concept of Collective Bargaining to Deal with America's Crisis Industries, in R. Adelman, ed., Proceedings of the N.Y.U. 39th Ann. Conf. on Labor Law, I-1, 14 (1986); Phillip I. Blumburg, Employee Participation in Corporate Decision-Making, in Alan F. Westin and Stephan Salisbury, eds., Individual Rights in the Corporation, 335, 337-338 (1980).

${ }^{11}$ See, e.g., Labor's Voice on Corporate Boards: Good or Bad?, Business Week 151, 1523 (May 7, 1984).

${ }^{23}$ See, e.g., Robert Moberly, Worker Participation and Labor-Management Cooperation Through Collective Bargaining, 15 Stetson L.Rev. 99, 101-103 (1985) (Eastern Airlines has given its unions access to financial data). See also AT\&T: The Labor Breakthrough that Never Was, Business Week 31 (November 4, 1985) (AT\&T shares sensitive financial data to convince its union to agree to cost reduction measures).
} 
Unions also have tried to obtain direct ownership in corporations through the creation of employee stock option plans with employee stock trusts, so as to have direct input into corporate decisions. ${ }^{23}$ Some unions have even attempted direct buyouts. ${ }^{24}$ In addition, some employers are establishing new types of employee involvement programs, which attempt to involve union members in discussions and decisions about many matters traditionally made by management. ${ }^{25}$

In these and other ways, labor is playing new roles in the corporation-roles of manager, owner, creditor, and financial advisor. In all of these roles, unions are not using the conventional tools that labor law offers. Rather, they are extending their influence into areas where current doctrine says unions may not tread.

These developments have something in common. They are forms of union involvement in corporate decision making that come about not by virtue of statutory right, but by virtue of the market power of particular unions. ${ }^{26}$ Furthermore, the means by which unions are exerting new power in corporate life stand in tension with the requirements of the National Labor Relations Act and are accordingly of questionable legality. ${ }^{27}$ These developments

${ }^{23}$ See, e.g., Steelworkers Sign Up for A Piece of the Action, Business Week 38 (April 8, 1985) (United Steelworkers of America negotiates employee stock ownership in exchange for substantial wage cuts); Making Money-and History-at Weirton, Business Week 136 (November 12, 1984) (describing 100 percent employee owned steel company); A Labor Package Gives Republic Room to Maneuver, Business Week 28 (July 16, 1984) (unions at Republic Airlines negotiate for $\mathbf{1 5 . 3}$ percent of the company in exchange for wage and work rule concessions).

${ }^{24}$ See, e.g., Eastern Holders at Contentious Meeting Clear Carrier's Acquisition of Texas Air, Wall Street Journal 50 (Nov. 26, 1986) (President of Machinist's Union vows to proceed with union plan to take over Eastern Airlines); A Brash Bid to Keep Steel in the Monogahela Valley, Business Week 30 (February 11, 1985) (unions attempting to arrange buyout of steel plant scheduled to be closed down).

${ }^{25}$ See, e.g., Smiling Fender to Fender, Business Week 39 (October 5, 1987) (Ford and United Auto Workers agree to contractual provision for joint labor-management committee to improve efficiency); How GM and the UAW Kept From Butting Heads, Business Week 32 (October 26, 1987) (joint labor-management committee at General Motors to develop plan to boost efficiency); What's Creating an 'Industrial Miracle' at Ford?, Business Week 80 (July 30,1984 ) (employee involvement programs effective in boosting morale, cutting costs, and reducing absenteeism). See generally John Hoerr, Why Recovery Isn't Getting Cooperation in the Workplace, Business Week 32 (February 20, 1984) (Department of Labor has recorded 200 companies with some form of quality-of-worklife programs at 800 plants and offices.)

${ }^{28}$ Bruce Simon, Labor at the Crossroads, in Charles Morris, American Labor Policy 303, 311-312 (1987) (Unions must use stock ownership plans, takeover battles, and corporate campaigns because the conventional labor law has been so weakened that it no longer promises meaningful protection.).

${ }^{27}$ See Part III. 
seem to contradict the conception of labor's role that is embedded in both the prevailing interpretation of the labor laws and in the traditional view of the corporation. The developments challenge our current understanding of the labor-management relationship and seem to require a new conception of the role of labor in the corporate structure.

\section{A. A New Departure in Labor Relations?}

Some contemporary labor relations scholars have noted the new developments in union participation and have argued that they signify a new departure in labor relations. ${ }^{28}$ These scholars claim that these developments represent a new form of labor relations, one based on cooperation rather than antagonism between labor and management. This form of labor relations, they argue, is distinct from and inconsistent with the adversarial model built into the current labor laws. ${ }^{29}$ Thus some have urged that labor law

${ }^{28}$ See, e.g., Robert Moberly, New Directions in Worker Participation and Collective Bargaining, 87 W.Va.L.Rev. 765, 784-5 (1985) (new forms of worker participation expand the collective bargaining process, even where collective bargaining law will not yet accommodate them); Charles B. Carver, The Vitality of the American Labor Movement in the Twenty-First Century, 1983 U.Ill.L.Rev. 633, 673-4 (Until recently, worker participation has been indirect, through the mechanism of collective bargaining, but unions now are exploring more direct forms of participation.); Thomas C. Kohler, Models of Worker Participation: The Uncertain Significance of Section 8(a)(2), 27 B.C.L.Rev. 499, 499 (1986) (New integrative methods of employee relations are an innovative departure from traditional forms of labor relations represented by collective bargaining.) But see, Herbert R. Northrup, Worker Participation: Industrial Democracy or Union Power Enhancement?, in Westin and Salisbury, eds., Individual Rights in the Corporation at 360 (cited in note 20) (In United States, some workers have already achieved participation rights via collective bargaining.).

29 See, e.g., John D. Blackburn, Worker Participation on Corporate Directorates: Is America Ready for Industrial Democracy?, 18 Hous.L.Rev. 349, 350 (1981) (under current federal labor law, codetermination is problematic); Kohler, 27 B.C.L.Rev. at 513 ("[T]he theoretical premises on which the collective bargaining model rests are distinctly different from participative schemes which are based on what has come to be referred to as an integrative model of industrial relations."); Albert G. Bixler, Industrial Democracy and the Managerial Employee Exception to the NLRA, 133 U.Pa.L.Rev. 441, 450 (1985) ("collective bargaining is incompatible with or destructive of a cooperative system of decision making"); Oberer, The Regulation of Union Economic Power, in Morris, American Labor Policy 270, 296-97 (cited in note 26) (questioning whether the independent labor union model is compatible with the Japanese model of "familial cooperation" and whether "free collective bargaining" can adapt to "the need for "embracing the boss" "). See generally Robert A. McCormick, Union Representatives as Corporate Directors: The Challenge To the Adversarial Model of Labor Relations, 15 U.Mich.J.L.Ref. 219 (1982) (detailing conflicts between labor law doctrines and union participation on corporate boards of directors). But see Carver, 1983 U.Ill.L.Rev. 633, 675-76 and 693 (cited in note 28) (no conflict between unions and employee representation committees or employee stock ownership schemes); Clyde Summers, Codetermination in the U.S.: A Projection of Problems and Potentials, $4 \mathrm{~J}$. of Comp.Corp.L. \& Soc.Reg. 155 (1982) (no necessary conflict between unions on Board of 
be re-examined and its fundamental premises challenged. For example, Steve I. Schlossburg, Deputy Undersecretary of Labor, has said that

[f]or the last 50 years, the law has assumed that labor and management are adversarial opponents and must have an arms-length relationship. . . . If we're going to be competitive in the global economy, we may have to blur distinctions between labor and management. ${ }^{30}$

Such statements signify that something new is happening in the labor law community. While pro-management scholars and lawyers have been calling for a repeal of the National Labor Relations Act since its inception, for the first time some pro-labor scholars and lawyers, and with them, some union officials, are now calling for a rethinking of labor regulation and are advocating that the NLRA be repealed. ${ }^{31}$

At the same time, the Department of Labor has initiated a five year project entitled "U.S. Labor Law and the Future of LaborManagement Cooperation," out of a belief that the labor laws are in conflict with the emerging forms of worker participation and cooperation. ${ }^{32}$ Both the Department of Labor study and the procla-

Directors and collective bargaining).

so Quoted in John Hoerr, America's Labor Laws Weren't Written for a Global Economy, Business Week 38 (January 13, 1986).

31 See notes 9-11. See also Clyde Summers, Past Promises, Present Failures and Future Needs in Labor Legislation, 31 Buff.L.Rev. 9, 17 (1982) ("The assumptions on which our labor law have been based for half a century have not been realized and its purposes have not been fulfilled"); Oversight Hearings on the Subject 'Has Labor Law Failed,' Part I, Joint Hearings Before the Subcommittee on Labor-Management Relations of the House Committee on Education and Labor, and the Manpower and Housing Subcommittee of the House Committee on Government Operations, 98th Cong., 2d Sess. 82 (1984) (statement of William B. Gould, Professor of Law, Stanford University) ("American labor law has failed to implement basic policy objectives enshrined in the N.L.R.A. itself") Julius Getman, Is the Labor Law Doing its Job?, 15 Stetson L.Rev. 93, 93-4 (1985) (reporting widespread disillusionment with labor law in the scholarly community).

${ }^{32}$ U.S. Labor Law and the Future of Labor-Management Cooperation, U.S. Dept. of Labor, B.L.M.R. Rept. No. 104 (1986). Steven Fetter, Executive Assistant to the Labor Department's Division of Labor-Management Relations and Cooperative Programs, recently explained the project this way:

Despite the shared desires of some employers and workers to adopt worker participation plans suited to the needs of their particular enterprises, it is not altogether clear that these new arrangements fit within the framework of our existing labor relations structure.

Labor relations in this country have been, and to a large degree continue to be, characterized by confrontation . . . . Cooperation, mutuality of interest, and principles of human relations have not been foremost in the parties' minds.

These concerns have led the Department of Labor to embark on a study of the nation's labor and related laws, and also collective bargaining traditions and practices, 
mations of the scholars raise the question of whether there is a fundamental incompatibility between collective bargaining and labor participation in management. This question is crucial for those who want to understand whether there are new possibilities for labor's role in corporate decision making and to formulate proposals to bring that about. Further, many of the same scholars who find a fundamental incompatibility also contend that the new participatory developments represent a new form of labor relations, based on cooperative rather than adversarial principles. While the claim about cooperation is related to the issue of incompatibility, the two issues are, in fact, distinct. Here, I want to address them both. ${ }^{3 s}$

\section{B. Overview}

For the remainder of Part I, I develop a distinction between two aspects of the labor law which makes it possible to map the various ways that the current laws affect union participation in corporate decision making. This distinction is between the constitutive aspects and the power broker aspects of the laws.

In Part II, I look at the many ways that the power broker aspects of the law facilitate, but also limit and prohibit, union participation in management decision making. I also show that those aspects of the labor law that broker union power have been subject to many doctrinal reversals and modifications during the fifty years that the NLRA has existed. I conclude that there is nothing inherent in the current system of regulation that would prevent a reinterpretation of these legal rules so as to reopen the possibilities for participation.

In Part III, I look at the current interpretations of the consti-

that may impede improvements in labor-management relations.

Steven Fetter, Labor/Management/Government Cooperation: The Key to Success in a Competitive World, 1987 Southwestern University Institute on Labor Law, 3-1, 3-6,7.

s3 Union participation in management must not be confused with "industrial pluralism," about which I have written previously. See Katherine Van Wezel Stone, The Post-War Paradigm in American Labor Law, 90 Yale L.J. 1509 (1981); Katherine Van Wezel Stone, Re-Envisioning Labor Law, 45 Md.L.Rev. 978 (1986). "Industrial pluralism," in my parlance, refers to a set of beliefs about labor-management relations and the relationship between the state and the workplace that has dominated judicial and scholarly thinking in the post-war era. The industrial pluralist paradigm painted a false picture of equality and participation, and prevented legal regulation from fostering equality and participation. By relying on a pretense of equality between management and labor, and by positing a fictitious joint labor-management control of the workplace, I argued that it stood in the way of efforts to achieve true participation. This article examines the prospects for true participation within the present regulatory regime. 
tutive aspect of the labor laws, and show that the new participatory developments are indeed in tension with them. I look at how the NLRB and courts treat employee stock ownership, union participation on boards of directors, and collective forms of direct decision making.

In Part IV, I explore the tensions between participation and the constitutive features of the Act in order to show that where the legal doctrines seem incompatible with participation, it is because the legal doctrines embody certain outdated and misleading assumptions about the nature of labor and management, the production process, and the contemporary corporation. I conclude that the asserted contradiction between participation and collective bargaining is apparent, not inherent.

In Part V, I discuss three related problems-those of market versus regulatory approaches to labor relations, subjective versus objective definitions of labor and management, and participation versus labor-management cooperation. I argue that participation is best viewed as collective bargaining broadened to other arenas. I conclude that, to the extent that participation is seen as desirable, it can succeed only with a regulatory structure that protects the formation of unions and constitutes them as a collective personality capable of contending for a voice in corporate decision making.

\section{The Two Facets of Current Labor Regulation}

There are two ways in which existing labor laws affect the market power of unions. First, they enable and facilitate the creation of the entity, "organized labor." I call this the "constitutive" effect of the labor laws. Second, they influence the power relations between organized labor and employers. I call this the "power broker" effect. It is my belief that while the constitutive effect of the labor laws is empowering for unions, the power broker effect, through recent interpretations of the statute, has become a limitation on union power in the market place. It is that limitation that has given rise to the new modes of labor activity.

1. The Constitutive Effect of the Labor Laws. One of the primary purposes and effects of the American labor laws ${ }^{34}$ is to enable

${ }^{34}$ By labor laws, I mean the National Labor Relations Act, 29 U.S.C. $§ \S 151-69$ (1982), the Labor Management Relations Act, 29 U.S.C. $\$ \S 141-97$ (1982), the Labor-Management Reporting and Disclosure Procedure Act, 29 U.S.C. $\$ \S 401-531$ (1982), and the Railway Labor Act, 45 U.S.C. $\$ \S 151-88$ (1982). These statutes comprise the federal regulatory scheme which is the dominant form of labor relations regulation in this country. Most states also have state labor relations laws which govern employees of state and local government and 
the establishment of labor as a collectivity. ${ }^{35}$ That is, the laws facilitate and protect organized, as opposed to individual, labor. The National Labor Relations Act furthers this collectivist end in several respects. First, it declares that employees have a right to organize and act collectively. ${ }^{36}$ It then implements this right by creating an administrative agency, called the National Labor Relations Board" ("NLRB"), authorized to conduct union elections and to certify the majority union as the exclusive bargaining representative for the bargaining unit. ${ }^{38}$

The NLRA also empowers the NLRB to regulate employer conduct that interferes with employee free choice and action in the union formation process. It does this primarily through the five employer "unfair labor practice" provisions," which spell out prohibitions and obligations placed on employer action in order to protect the exercise by employees of the rights to organize and act collectively. ${ }^{40}$ The employer unfair labor practices can be under-

other employees who are not otherwise covered by the federal labor relations legislation. These laws are usually patterned on one of the federal labor relations laws.

ss The drafters of the original Wagner Act believed that labor and the economy were best served when the workforce was organized into unions which could act as a countervailing force to the power of the employers. For this reason, they tried to promote and protect the formation of collective entities of employees. See, e.g., Ellis Hawley, The New Deal and the Problem of Monopoly 187-190 (1966) (describing emergence of view that it was in the public interest for government to promote the organization of the economically weak); Irving Bernstein, The New Deal Collective Bargaining Policy 28 (1950) (quoting Senator Wagner on importance of permitting labor to bargain collectively). To further this goal, the original Wagner Act articulated certain "rights" of employees to organize and act collectively, 29 U.S.C. $\$ 157$, and imposed certain prohibitions and obligations on employer action, called "unfair labor practices," in order to protect the exercise by employees of those rights, 29 U.S.C. \$158. Even though the statute was subsequently amended to add unfair union labor practices, aimed at certain perceived union abuses, 29 U.S.C. \$158(b), the NLRA's commitment to facilitate organized labor remained unchanged. See generally, Lee Modjeska, Labor and the Warren Court, 8 Indus.Rel.L.J. 479 (1986) (demonstrating the multitude of ways in which the Warren Court interpreted the NLRA so as to affirm its commitment to employee collective action).

s6 29 U.S.C. Preamble and $\$ 157$.

s7 29 U.S.C. $\S \S 153,154$, and 155.

ss 29 U.S.C. \$159.

so The employer unfair labor practices in the NLRA are found in 29 U.S.C. $\$ 158(\mathrm{a})$. The NLRA also contains union unfair labor practices in 29 U.S.C. $\$ 158(\mathrm{~b})$. These provisions prohibit certain union practices, such as union refusals to bargain, union discrimination against employees on the basis of union membership or lack thereof, and certain types of secondary activity. The union unfair labor practices were added to the NLRA as part of the 1947 amendments to the NLRA.

10 The NLRB also has the ability to police employer conduct through its power to hold elections and certify bargaining units. See Excelsior Underwear Inc., 156 N.L.R.B. 1236, 1239 (1966) (distinguishing NLRB's powers in elections from its powers to determine the existence of unfair labor practices); General Shoe Corp., 77 N.L.R.B. 124, 126 (1948). 
stood together as furthering the collectivist aim of the statute by helping to create and protect an employee group entity, thereby empowering that group vis-a-vis the employer. ${ }^{41}$

To the extent that the unfair labor practices can thus be understood as protecting formation of an autonomous group identity, they comprise the constitutive aspect of the NLRA. They express a

4 All of the unfair labor practices can be understood as furthering the collectivist aim of the statute. For example, $\S 8(a)(1), 29$ U.S. $\$ 158(a)(1)$, prohibits an employer from interfering with employees in exercising their $\$ 7$ rights to organize and act collectively. It is the summation and general statement of all the other employer unfair labor practices. In addition, it is used to regulate employer conduct during union election campaigns, and hence, to protect the group-formation process. The courts and the Board decide questions under $\S 8(a)$ (1) by balancing the rights of employees to organize with the rights of employers to run their businesses as they please. Textile Workers v. Darlington Co., 380 U.S. 263, 268-69 (1965) (dicta); see also, Republic Aviation Corp. v. N.L.R.B., 324 U.S. 793, 797-98, 802-04 \& n.8, n.10 (1945) (balancing employees rights to organize with employer's rights to limit solicitation on its property); N.L.R.B. v. Gissel Packing Co., 395 U.S. 575, 617 (1969) (balancing employees' rights to organize with employer's rights to express its views regarding unionization efforts).

Section 8(a)(3), 29 U.S.C. $\$ 158(a)(3)$, makes it unlawful for an employer to discriminate on the basis of union activity. This has been interpreted to mean that an employer is prohibited from taking actions that adversely affect individuals or groups of individuals if those actions are motivated by anti-union sentiments. American Shipbuilding Co. v. N.L.R.B., 380 U.S. 300, 313 (1965); Thomas G.S. Christensen and Andrea Svanoe, Motive and Intent in the Commission of Unfair Labor Practices: The Supreme Court and the Fictive Formality, 77 Yale L.J. 1269, 1315 (1968). Stated another way, this provision prohibits an employer from punishing employees for organizing or acting collectively. Christensen and Svanoe, id. at 1278; Getman, Section 8(a)(3) of the N.L.R.A. and the Effort to Insulate Employee Free Choice, 32 U.Chi.L.Rev. 735, 736 \& n.6 (1965) (basic purpose of $§ 8(a)(3)$ is "to prevent an employer from using his views of unions and their members as the basis for punishing or rewarding employees"). Thus, it affirms the collectivist purpose of the Act.

Section $8(a)(5), 29$ U.S.C. $\$ 158(a)(5)$, imposes an obligation on the employer to bargain with the union. This obligation requires the employer to go through at least minimal efforts to reach agreement on certain key issues in the employment relationship, and it prohibits the employer from making unilateral changes in those areas until the bargaining obligation has been satisfied. N.L.R.B. v. Katz, 369 U.S. 736 (1962). The bargaining obligation thus means that the employer cannot circumvent the collective representative in operating an establishment, at least in those areas where the obligation reaches. Stated differently, an employer may not "stonewall," and thus render a union irrelevant, by refusing to deal with it regarding issues of wages, hours, and conditions. Section $8(a)(5)$ prohibits stonewalling because it has the effect of destroying the union's legitimacy in the eyes of the employees and hence its potency as a collective voice. As the Supreme Court said in N.L.R.B. v. Insurance Agents, 361 U.S. 477, 484-85 (1960), "[T]he duty of management to bargain in good faith is essentially a corollary of its duty to recognize the union."

The other unfair labor practices similarly prohibit certain employer behaviors that are detrimental to the formation and autonomy of a collective entity. Section 8(a)(2) prohibits the employer from setting up a phony, sham union and using its coercive power to force its employees to join. Section $8(a)(4)$ prohibts reprisals against employees participating in proceedings to enforce their rights under the other sections of the statute. These sections too guarantee group rights by making it unlawful for an employer to deprive an employee of the benefits of the statute. 
public commitment to change the unit of labor from individual to collective. Just as the corporate collective form facilitates the use of capital markets, so too many supporters of organized labor have argued that the collective form of labor leads to an improvement in the functioning of the labor market. ${ }^{42}$

2. The Power Broker Effect of the Labor Laws. In addition to the features of the NLRA which involve the creation and empowerment of collectivities, the NLRA also has features which determine the relative power that management and labor will have in their mutual dealings. In many aspects of industrial life, legal rules determine what actions labor and management may take vis-a-vis each other to further their own separate interests. For example, unions often engage in strikes to further their demands. They also seek to enlist the assistance of others through picketing and boycotts. Both the labor law and laws of general applicability define which of these tactics are lawful and set the ground rules for their exercise. Such rules cannot be avoided, and yet the content of each rule selected affects the power of each side relative to the other. That is, they are "zero sum" rules. I call rules of this type "power broker" rules because they are legal rules which broker, or allocate, the relative power of management and labor. ${ }^{43}$

I do not believe any easy generalization about the overall impact of the NLRA on the market power of unions is possible, at least not without a much more detailed study than I am present-

12 Hawley, in The New Deal and the Problem of Monopoly 195-96 (cited in note 35), states that Wagner Act proponents believed that a strong labor organization was necessary to counterbalance big business in order to attain social justice and economic balance. They argued that in order for the economy to recover from the depression, unions were necessary to redistribute national income toward labor. See also Bernstein, The New Deal Collective Bargaining Policy at 133 (cited in note 35 ) (prosperity required a higher level of wages, which collective bargaining would bring about.) For a contemporary study which reaches the same conclusion on the basis of quantitative data analysis, see Richard Freeman and James L. Medoff, What Do Unions Do? 19 (1984) (unions generally improve efficiency, reduce earnings inequality, and improve economic and social freedom).

4s For examples of power broker rules resulting from interpretations of the labor law, see, Jacksonville Bulk Terminals v. Int'l Longshoremen's Ass'n, 457 U.S. 702 (1982) (employees' political strike may not be enjoined); Buffalo Forge Co. v. United Steelworkers of America, 428 U.S. 397 (1976) (union's sympathy strike may not be enjoined); N.L.R.B. v. Fansteel Corp., 306 U.S. 240 (1939) (employees' sit-down strike not protected activity under the labor laws); Elk Lumber Co., 91 N.L.R.B. 333 (1950) (employees' slowdown in response to wage cut not protected activity). For examples of power broker rules which result from general laws, see, Sears, Roebuck \& Co. v. Carpenters, 436 U.S. 180, 196-98, 200 (1978) (upholding the application of state trespass laws against union picketing); Hudgens v. N.L.R.B., 424 U.S. 507 (1976) (union's peaceful picketing of shopping center not protected by First Amendment); Loewe v. Lawlor, 208 U.S. 274 (1908) (union secondary product boycott unlawful under the Sherman Antitrust Act). 
ing. However, I do believe that it is possible to understand how the current interpretations of the NLRA affect the ability of unions to participate in corporate decision making. In recent years, a unified picture has emerged from several doctrinal areas. It is a picture of constraint, a picture of corporate decision making in which labor is just not there. I develop this picture in Part II.

\section{Barriers to Participation IN the NLRA's POWER.BROKER RULES}

In this section, I describe those aspects of the NLRA's substantive provisions that most directly affect labor's ability to influence corporate investment and production decisions. In particular, I look at the duty to bargain ( $\$ 8(a)(5))$, the prohibitions on management's deliberate anti-union activities $(\$ 8(a)(3))$, the rules of successorship, and the limitations on the ability of unions to obtain protection by contract. In tracing the doctrinal developments in each of these areas, I show that the legal rules in effect have recently been changed so as to diminish the participation possibilities for unions. This pattern explains why the new participatory forms are located outside of the structure of the NLRA.

However, there is another lesson to be learned from the history of these various doctrines. Many of the doctrines which now serve as barriers to participation were interpreted otherwise during earlier periods in the NLRA's history. Thus, by minor alterations of certain key doctrines, the NLRA could be reinterpreted to facilitate, rather than constrain, union participation in corporate decision making.

\section{A. The Duty to Bargain Over Investment Decisions}

Section 8(a)(5) of the NLRA says that management has a duty to bargain with a union over "wages, hours and other terms and conditions of employment." the duty to bargain, has been interpreted to mean that an employer must meet with the bargaining agent of its employees and make at least minimal efforts to reach agreement regarding terms and conditions of employment. That is, the statute compels both

429 U.S.C. $\$ 158(a)(5)$. This provision says that it is an unfair labor practice for an employer to "refuse to bargain collectively with the representatives of his employees . . .." The meaning of the term "bargain collectively" is defined in $\$ 8(d), 29$ U.S.C. $\$ 158(d)$, as the obligation to meet and confer in good faith "with respect to wages, hours, and other terms and conditions of employment ... but such obligation does not compel either party to agree to a proposal or require the making of a concession." 
parties to engage in certain "proper" bargaining behavior. However, while such minimal motions are mandated, the statute makes it clear that neither party is compelled to make concessions or reach agreement. ${ }^{45}$ Furthermore, the courts and the National Labor Relations Board will not judge the reasonableness of the positions that either side takes at the bargaining table, so long as the etiquette of bargaining is observed. ${ }^{48}$

Although $\S 8(a)(5)$ may sound like it does nothing more than direct management and labor to engage in hollow gestures and meaningless acts, ${ }^{47}$ the provision is particularly important when corporate transformations and investment decisions are taking place. Section $8(a)(5)$ has been interpreted to mean not only that parties must bargain, but also that management may not make unilateral changes in those topics which are subject to the bargaining obligation until it has discharged that obligation by engaging in good faith bargaining to "impasse." 48 Thus the duty to bargain requires that, on those issues that fall within the definition of mandatory bargaining, management must seek union participation, consultation, and consent before taking action. ${ }^{48}$ As a result, the

${ }^{45} 29$ U.S.C. $\$ 158(d)$. But see, Note, Good Faith Bargaining With No Concessions Under the N.L.R.A.-An Intractable Antinomy, 49 N.D.L.Rev. 85, 88-89 (1972) (discussing paradox that NLRB cannot determine good faith without judging the reasonableness of the proposals made).

18 White v. N.L.R.B., 255 F.2d 564 (5th Cir. 1958) (NLRB should not judge the reasonableness of the proposals).

${ }^{47}$ See James B. Atleson, Management Prerogative, Plant Closings, and the NLRA, 11 N.Y.U.Rev.L. \& Soc.Change 83, 89. ("[A] weak union gains little power from an NLRB determination that its employer refused to bargain about a mandatory subject").

${ }^{48} \mathrm{Katz}, 369$ U.S. 736 (employer violates $\S 8(a)(5)$ by making unilateral change in mandatory item prior to reaching impasse in negotiations with the union). The term "impasse" is a term of art in labor law. It means the point at which the parties agree, or the Federal Mediation and Conciliation Service concludes, that further bargaining would be futile. Neither party can unilaterally declare an impasse. Once impasse is reached, both parties are free to use economic weapons to press for the positions they took at the bargaining table. See N.L.R.B. v. J.H. Bonck Company, 424 F.2d 634, 638 n.9 (5th Cir. 1970) (impasse is the point where parties have exhausted the bargaining possibilities and where further meetings would be fruitless). See also Robert A. Gorman, Basic Text on Labor Law, Ch. 20 $\S 12$ (1976) (definition and significance of "impasse").

18 After impasse is reached, the employer can take the contemplated action unilaterally, so long as it is consistent with proposals presented to the union during negotiations. Katz, 369 U.S. at 745 n.12. Recently the NLRB held in Milwaukee Spring Division (II), 268 N.L.R.B. 601, 611-12 (1984), enf. sub. nom. Int'l Union, U.A.W. v. N.L.R.B., 765 F.2d 175 (D.C.Cir. 1985), that when a collective bargaining agreement is in effect, an employer can unilaterally modify it by altering a mandatory item after first bargaining with the union to impasse, so long as the particular modification is not prohibited by the existing collective agreement. But see Laurence Gold, Current N.L.R.B. Law on the Duty to Bargain with Regard to Plant Closings, Work Transfers and Removals, and Related Problems, 15 Stetson L.Rev. 115, 120 (1985) (criticizing Milwaukee Spring). 
bargaining obligation embodied in $\S 8(a)(5)$ could be a significant obstacle to an employer who wants to make a decision that requires major expenditures and clockwork timing but which nonetheless is the subject of mandatory bargaining.

There has been considerable controversy throughout the history of the NLRA about which decisions are subject to mandatory bargaining. ${ }^{50}$ From the end of World War II until 1980, it was commonly believed that the realm of mandatory bargaining was infinitely expandable. Thus judges and scholars spoke of an expanding realm of collective bargaining that would eventually bring all matters of importance to labor into the arena of joint decision making, ${ }^{51}$ so that ultimately the duty to bargain would embrace most corporate decisions. ${ }^{52}$ This view was intimately connected with the industrial pluralist paradigm of labor relations, in which management and labor are seen as co-equal parties in a legislature, together formulating the rules of their joint governance. ${ }^{53}$

The Supreme Court gave expression to the belief that the scope of bargaining was infinitely expandable in the majority opin-

${ }^{80}$ See, e.g., Fibreboard Corp. v. N.L.R.B., 379 U.S. 203 (1964) (employer has a duty to bargain over decision to subcontract union work); First National Maintenance Corp. v. N.L.R.B., 452 U.S. 666, 686 (1981) (employer does not have duty to bargain over decision to close part of its operation); Allied Chemical Workers v. Pittsburgh Glass, 404 U.S. 157 (1971) (employer has no duty to bargain over pension benefits for retired employees); Ford Motor Co. v. N.L.R.B., 441 U.S. 488 (1979) (employer has duty to bargain over prices of food in company cafeteria). See generally Millspaugh, 8 J.Corp.L. at 487 (cited in note 6) (scope of mandatory bargaining has "long been a major battleground" between management and labor).

${ }^{81}$ N.L.R.B. v. Borg-Warner Corp., 356 U.S. 342, 358-59 (Harlan concurring and dissenting) (discussing "evolving character of collective bargaining agreements"); N. Chamberlain \& J. Kuhn, Collective Bargaining 106-07 (2d ed. 1965) (no limit to areas in which unions will seek input); Houston Clinton, Jr., The Expanding Scope of Terms and Conditions Subject to Collective Bargaining, 6 Baylor L.Rev. 150, 170 (1954) ("scope of bargaining may be expected to continue its expansion absent specific and limiting legislation").

${ }^{82}$ In part, this conception grew out of the observation that the topics of collective bargaining were expanding and would continue to do so. For example, many noted that bargaining over fringe benefits, which had been considered taboo by employers in the 1940s was generally accepted by the late 1950s. See, e.g., Rabin, 71 Colum.L.Rev. at 815 (cited in note 3) (the number of subjects considered mandatory has expanded "as parties have discussed a wider variety of issues at the bargaining table"). From facts like these, scholars and participants in industrial relations came to believe that management would eventually see that it was advantageous to make decisions with union input, and that unions would gain sufficient experience in management matters to make them mature and constructive in their judgment and outlook. Thus, experts in industrial relations believed that collective bargaining would build mutual respect and trust, which would enable the parties to learn to work together for their mutual benefit.

${ }^{53}$ For a general discussion of the expanding realm conception of collective bargaining and its relationship to the general industrial pluralist perspective, see Stone, 90 Yale L.J. at 1578-1579 (cited in note 33). 
ion in Fibreboard v. N.L.R.B. ${ }^{54}$ There, an employer decided to subcontract its maintenance work to an outside shop without first bargaining with the union that represented the maintenance workers. The Supreme Court found that the decision to subcontract was subject to mandatory bargaining, and that the employer had thus violated its duty to bargain by agreeing to subcontract the work without first bargaining with the union about the decision. As a remedy, it ordered that the subcontracted work be restored to the bargaining unit. The Fibreboard Court found the decision to subcontract work to be mandatory because the Court said that such matters were of "vital concern" to management and labor. Making them mandatory subjects of bargaining thus furthered the NLRA's goal of promoting industrial peace. ${ }^{55}$ This reasoning suggests a broad interpretation of the duty to bargain. ${ }^{56}$

Justice Stewart, in an influential concurrence, disputed the aspect of the Court's opinion which "seems to imply that any issue which may reasonably divide an employer and his employees must be the subject of compulsory collective bargaining."Br Rather, he argued that a bargaining obligation should not attach to those decisions which are at the "core of entrepreneurial control." plified this idea by distinguishing between decisions which have a direct effect on employment security and decisions which have a direct effect on the nature of the enterprise and only an indirect effect on employment security. He argued that bargaining should be required for the former but not the latter. Thus Stewart's concurrence suggested a direct/indirect distinction for deciding which issues were subject to mandatory bargaining. He went on to say that to require bargaining on "core" subjects about the nature of the enterprise would "mark a sharp departure from the traditional principles of a free enterprise economy." "58

Neither opinion in Fibreboard said that all decisions were in the realm of mandatory bargaining, but the majority decision suggested an expansive approach to the question. Later cases stressed

s4 379 U.S. 203 (1964).

ss Id. at 211 . However, it should also be noted that despite the broad nature of its analysis, the majority also suggested, in dicta, that had there been major capital investment involved or a change in the company's "basic operation," the outcome might have been different. Id. at 213.

so Modjeska, 8 Ind.Rel.L.J. at 498-499 (cited in note 35) (Fibreboard created broad bargaining rights for unions).

67379 U.S. at 221.

s8 Id. at 223.

so Id. at 225-226. 
this point in arguing for the expanding realm. ${ }^{60}$ And in the ensuing years, the NLRB, pursuant to Fiberboard, required employers to bargain over many instances and forms of subcontracting. ${ }^{.1}$ It also went further, and required bargaining about decisions that had nothing to do with subcontracting, such as decisions to eliminate job categories, ${ }^{62}$ automate production, ${ }^{63}$ transfer work from one location to another, ${ }^{64}$ sell part of the business, ${ }^{65}$ and close part of an operation. ${ }^{68}$ At least in the NLRB's interpretation of Fibreboard, the case established a very broad mandatory bargaining obligation, almost a presumption, for many different kinds of corporate investment and production decisions. ${ }^{67}$ However, the courts of appeals did not always concur. ${ }^{68}$

In 1981, the Supreme Court again addressed the scope of a unions's right to compel bargaining over corporate investment and production decisions. In First National Maintenance Corp. $v$. N.L.R.B., ${ }^{68}$ it held that bargaining was not required over an employer's decision to close part of its operation even though that decision was based on the employer's desire to lower labor costs. In setting forth its reasons, the Court reformulated $\S 8(a)(5)$ and re-

6o But see Allied Chemical Workers, 404 U.S. at 157 (issues concerning retired employees' pension benefits not subject to mandatory bargaining). This decision demonstrated that the realm of mandatory bargaining was not infinitely expandable. However, the issue in that case did not concern the bargaining unit employees directly. Until 1981, therefore, it was possible to believe that all issues concerning employees in the bargaining unit would be gradually brought into the realm of mandatory bargaining.

${ }^{\circ 1}$ Adams Dairy Inc., 137 N.L.R.B. 815 (1962); Union Carbide Corporation, 178 N.L.R.B. 504 (1969); Westinghouse Electric Corp., 150 N.L.R.B. 1574 (1965).

${ }^{62}$ Metromedia, Inc., 182 N.L.R.B. 202 (1970).

as The Renton News Record, 136 N.L.R.B. 1294 (1962).

64 Weltronic Company, 173 N.L.R.B. 235 (1968).

${ }^{6 s}$ Ilfeld Hardware \& Furniture Co., 157 N.L.R.B. 1401 (1965).

${ }^{68}$ Red Cross Drug Co., 174 N.L.R.B. 86 (1969); Ozark Trailers, Inc., 161 N.L.R.B. 561 (1966).

67 See Note, Partial Closings: The Scope of an Employer's Duty to Bargain, 61 B.U.L.Rev. 735, 750-51 (1981) (NLRB requires bargaining over partial shut-downs in most situations); Rabin, 71 Colum.L.Rev. at 804 (cited in note 3) (On the basis of Fibreboard, "the NLRB has required bargaining in connection with virtually every kind of decision that impairs employment security, while the courts have exempted from the bargaining obligation those decisions that involve fundamental management rights").

${ }^{88}$ See, e.g., N.L.R.B. v. Adams Dairy, Inc. 350 F.2d 108, 111, (8th Cir. 1965)(partial liquidation not subject to duty to bargain). See generally Atleson, 11 N.Y.U.Rev.L. \& Soc.Change 83, 101-104 (cited in note 47) (on differing interpretations of Fibreboard by courts and the NLRB); Thomas J. Schwarz, Plan Relocation or Partial Termination-The Duty to Decision-Bargain, 39 Fordham L.Rev. 81, 86-87 (1970) (conflict between NLRB and courts on employers' duty to bargain over relocation and partial closing decisions). But see Brockway Motor Trucks v. N.L.R.B., 582 F.2d 720, 726 (3d Cir. 1978) (citing cases on broad range of issues the courts have found to be mandatory subjects of bargaining).

${ }_{68} 452$ U.S. 666 (1981). 
cast its previous Fibreboard decision so as to diminish a union's right to bargain over employer investment or production decisions. It said that even for those decisions that have a direct impact on employment opportunities, bargaining would not be required unless the issue was "amenable to resolution through collective bargaining." The Court then established a balancing test to determine which issues are subject to mandatory bargaining. This test required management to bargain about a decision "only if the benefit, for labor-management relations and the collective bargaining process, outweigh[ed] the burden placed on the conduct of the business."

The First National Maintenance decision signified a major retreat from the ideal of industrial democracy and shared decision making between management and labor over the terms and conditions of employment. ${ }^{21}$ The decision introduced new factors to consider and new criteria to decide the scope of labor's bargaining rights. Most notably, it introduced, as a factor to be balanced, the degree of burden that bargaining would place on management. ${ }^{72}$ This factor meant that the employer's market constraints, or rather, an employer's view of its market constraints, would be relevant to the application of $\S 8(a)(5) .^{73}$

The NLRB did not immediately adopt the First National Maintenance balancing test in all its $\S 8(\mathrm{a})(5)$ decisions, possibly

${ }^{70}$ Id. at 679 . The Court stated that this did not alter the employer's obligation to bargain over the effects of its decision. Id. at 677 and $n$. 15. This obligation was established long ago as part of mandatory bargaining under $\$ \S 8(a)(5)$ and 8(d). See Id. at $681 \mathrm{n.15}$; Shell Oil Co., 149 N.L.R.B. 305, 307 (1965); Millspaugh, 8 J.Corp.L. at 488 (cited in note 6). The Court in First National Maintenance suggested that the requirement that the employer bargain with the union over the effects of the decision, in conjunction with the NLRA's prohibition in $\S 8(a)(3)$ against actions specifically taken to evade the union, was adequate protection for the union in most cases. 452 U.S. at 681-3.

${ }^{71}$ See Atleson, 11 N.Y.U.Rev.L. \& Soc.Change at 106 (cited in note 47) (First National Maintenance "shows the extent to which the Court has simply expunged the policy of encouraging industrial democracy from the Act"); Gould, 24 San Diego L.Rev. at 64 (cited in note 4) (First National Maintenance turns Warren Court duty to bargain precedent "on its head.") Robert Connerton, Collective Bargaining: A Process Under Seige, in Morris, American Labor Policy 246, 248-49 (cited in note 26) (First National Maintenance ended the presumption of mandatory bargaining that Fibreboard created).

72 First National Maintenance, 452 U.S. at 689 (Brennan dissenting) ("I cannot agree with this [balancing] test, because it takes into account only the interests of management; it fails to consider the legitimate employment interests of the workers and their union").

${ }^{73}$ For approval of this aspect of the First National Maintenance decision, see Note, Unfair Labor Practice and Contract Aspects of an Employer's Desire to Close, Partially Close, or Relocate Bargaining Unit Work, 24 Duquesne L.Rev. 285, 306-08 (1985) (First National Maintenance will facilitate the free flow of capital essential to insure economic growth and to withstand international competition). 
because the factors on each side of the balance were so vague as to make the test extremely difficult to apply. ${ }^{74}$ Thus, in order to avoid the test, the NLRB increasingly focused on the other aspect of the First National Maintenance reasoning-the language stating that mandatory bargaining should be limited to those decisions that were "amenable" to collective bargaining. However, the notion of "amenability" also proved to be a poor litmus test for distinguishing mandatory from permissive subjects of bargaining because it, like the balancing test, is both ambiguous and vague.

There has been considerable disagreement about precisely what it means to say that a decision is "amenable to collective bargaining." In a leading case, Otis Elevator, ${ }^{75}$ the NLRB attempted to interpret First National Maintenance, and split three ways. All

74 There are very few cases in which the balancing test has even been attempted. One of the few is Pennsylvania Energy Corp., 274 N.L.R.B. 1153 (1985), where the NLRB balanced the factors and held that an employer was required to bargain about its decision to subcontract all its bargaining unit work and lay off all its employees. The decision was written by Member Dennis who, alone on the NLRB, has advocated that the balancing test should be applied in each case. See Otis Elevator, 269 N.L.R.B. 891, 895-900 (1984) (Dennis concurring).

The NLRB's more customary approach to post-First National Maintenance cases has been to characterize the decision as either a partial closing or a subcontract, and then to let the category dictate the result. Thus, in Fiberboard-type subcontracting situations, bargaining was required, and in First National Maintenance-type economically-motivated partial shut-downs, bargaining was not required. This per se approach effectively avoided the impossible balancing test in many cases. See, e.g., Swift \& Co., 264 N.L.R.B. 240, 243 (1982) (characterizing decision to close a processing operation as a partial shutdown so that no bargaining was required, even if bargaining were expedient, or advantageous to one or both parties, or caused no harm).

However, this approach did not solve all the problems because there were many fact patterns that did not fall neatly into one of the two categories, but rather possessed characteristics of both. See Bob's Big Boy Family Restaurants, 264 N.L.R.B. 1369, 1371 (1982), where an employer decided to shut down its shrimp preparation department, lay off its shrimp-processing employees, and purchase shrimp processed by a food supplier. The majority of the NLRB found the employer's action to be a subcontract and thus held that predecision bargaining was required. However, two NLRB members, in dissent, said that the employer engaged in a partial shut-down and that the decision thus should be governed by First National Maintenance. Id. at 1373-74. See also Whitehead Brothers Co., 263 N.L.R.B. 895,898 (1982) where a company that processed foundry materials terminated its trucking operations and transferred its delivery work to outside trucking firms. The NLRB found a subcontract, not a partial shutdown, so that it was governed by Fibreboard, not First $\mathrm{Na}$ tional Maintenance.

However, as Board Member Jenkins noted in Liberal Market, Inc., 264 N.L.R.B. 807, 808 (1982) (dissenting opinion), many cases fall between Fibreboard and First National Maintenance on the spectrum, and that "in fact, it is frequently difficult to draw a clear line between Fibreboard-type subcontracting and Ozark-type partial closing." In 1984 the Board solved this problem by extending the First National Maintenance decision to employer decisions to subcontract, restructure, and invest in labor-saving machinery. United Technologies, 115 L.R.R.M. 1281 (1984).

${ }^{75} 269$ N.L.R.B. 891 (1984). 
three opinions agreed that "amenability" refers to the employer's motive for making a particular decision, rather than such factors as the parties' previous history of bargaining about similar decisions or the prevalence of bargaining over such issues in the industry or elsewhere. The plurality stated that a decision is "amenable" to collective bargaining when it "turns on" labor costs rather than on a "change in the nature or direction of the business." tion has remained the dominant NLRB interpretation of the duty to bargain. ${ }^{77}$ NLRB Member Zimmerman, in his dissent, argued for a broader notion of "amenability," such that a decision based on an employer's overall costs, not merely labor costs, could also be "amenable" to bargaining and therefore within the realm of mandatory bargaining. ${ }^{78}$ Zimmerman argued that a bargaining obligation should attach to decisions that turned on overall costs, because, in those cases, a union's concession could conceivably convince an employer to change its mind. ${ }^{79}$

A wholly different approach was urged by NLRB Member Dennis in her Otis concurrence. She maintained that First $\mathrm{Na}$ tional Maintenance set forth a two-step analysis, and that the amenability factor and the balancing test were two necessary and distinct preconditions for mandatory bargaining. ${ }^{80}$ Like the others, she treated "amenability" as a question of what motivated the employer's decision. However, she said that a decision was "amenable" to bargaining if the employer's decision was motivated by any factor over which the union has control. ${ }^{81}$

These different interpretations of First National Maintenance

76 Id. at 892.

77 See, e.g., DeSoto, Inc., 278 N.L.R.B. No. 114 (1986) (no duty to bargain over decision to close one of ten plants because decision was based on overall excess capacity and effciency considerations, not labor costs.); Mack Trucks, 277 N.L.R.B. 711 (1985) (no duty to bargain over decision to consolidate operations because decision made on basis of cutting freight and overhead costs, not labor costs); Metropolitan Teletronics, Inc., 279 N.L.R.B. No. 134 (1986) (no duty to bargain over decision to relocate because decision motivated by impending foreclosure action against current facility and lower costs at new facility, not labor costs).

78 Otis Elevator, 269 N.L.R.B. at 900-901 (Zimmerman dissenting).

79 Id. Zimmerman's analysis might have lead to different outcomes in the cases cited in note 77 because, in each case, overall employer costs were the decisive factor in the decision. Thus, it could be argued that in each case, concessions by the union would have affected overall profitability, and hence influenced the employer's ultimate decision.

${ }^{s 0}$ Dennis' two-step approach has not prevailed. See, e.g., Columbia City Freight Lines, Inc. 271 N.L.R.B. 12 (1984), where the NLRB affirmed the conclusion of the ALJ but rejected its analysis because the ALJ had engaged in a balancing test. Instead, the majority applied an Otis plurality analysis in which it found that bargaining was not required because the decision did not turn on labor costs. Id. at 13.

${ }^{81}$ Otis Elevator Co., 269 N.L.R.B. at 897. 
have transformed the realm of mandatory bargaining from an infinitely expandable field defined by an external standard of ideal industrial practice to a field determined by the employer's subjective state. Under all of the opinions in Otis, the employer's characterization of the reasons for its decisions determines whether those decisions are mandatory subjects of bargaining. Yet another crucial ambiguity remained however. The plurality in Otis divided all cases into two types: those in which the employer's motive is to reduce labor costs and those in which its motive is to change or restructure the business. ${ }^{82}$ This duality. omits the situation that arises most frequently: Disputes over management decisions which are motivated by concern for general economic difficulties of a company, or which are made to maximize efficiencies or profits on the basis of the company's general economic situation. On the face of it, these decisions would fit into neither of the Otis categories. These decisions do not necessarily "turn on" labor costs, nor are they a fundamental change in the nature of the business. They are simply management's response to the ever-changing economic climate in which it operates. These decisions seem "amenable" to collective bargaining because they could potentially be affected by concessions a union could give. ${ }^{83}$

In recent cases, the Otis plurality has become the majority and has modified its Otis test so as to preclude bargaining over decisions that do not directly turn on the narrowest possible view of labor costs. The new Otis test says that a decision is amenable to bargaining only if it turns on "contractual labor costs," "bargaining unit labor costs." "Thus decisions based on labor costs in general are no longer subject to mandatory bargaining.

Furthermore, the Otis test left open the question of how to treat situations where the employer has more than one motive for a decision, or where the motive can be characterized in more than one way. Frequently, post-Otis $\$ 8(\mathrm{a})(5)$ cases turn on whether the employer's motive was to reduce bargaining unit labor costs or to

${ }^{82}$ From an economic point of view, the distinction between reducing labor costs and restructuring a business is incoherent. All businesses aim to improve profitability, in the middle-run, if not in the short run. In pursuing this aim, businessmen are, in theory, indifferent as to whether they achieve it by reducing labor costs or by restructuring other aspects of the operation. Edwin Mansfield, Microeconomics: Theory and Application 360-86 (4th ed. 1982) (on business' employment of inputs under perfect competition).

${ }^{83}$ See, e.g., Milwaukee Spring (II), 268 N.L.R.B. at 608 (Zimmerman dissenting) (company's relocation decision would have been different had union agreed to reduce wages).

B4 DeSoto, Inc., 278 N.L.R.B. No. 114 (1986); Inland Steel Container Co. 275 N.L.R.B. 929, 936 (1985).

${ }^{85}$ Mack Trucks, 277 N.L.R.B. at 712 (1985) (emphasis supplied). 
reduce overall costs-a distinction that becomes thin as gossamer. The NLRB has recently taken the position that a decision will be subject to mandatory bargaining only if it was motivated solely by a desire to reduce labor costs. ${ }^{86}$ Mixed motive cases are decided in favor of the employer. ${ }^{87}$

A particularly striking case is that of Inland Steel Container Corp. ${ }^{88}$ where an employer admitted that its decision to relocate and lay off its unionized work force was precipitated by contractual labor costs and stated that if the union had given concessions, the employer would not have made the decision it did. In the face of this evidence, the Administrative Law Judge ("ALJ") said he was persuaded that:

'contractual labor costs' was a precipitating factor in Respondent's search for a new facility. On the other hand, contrary to the General Counsel, I cannot find on the total state of this record that the decision turned solely on, or even was predominantly motivated, by a desire to avoid 'contractual labor costs. ${ }^{89}$

Rather, the ALJ pointed to the company's other economic difficulties, such as obsolete equipment and inefficient plant design in the old facility, to find that the decision was based on overall costs, not contractual labor costs alone. This decision was affirmed and adopted by the NLRB. ${ }^{90}$

The NLRB's post-Otis approach insulates most employer decisions involving capital investment or corporate transformation.

${ }^{86}$ Hawthorn Mellody, Inc. 275 N.L.R.B. 339, 341 (1985) (no duty to bargain about decision to partially shut down); Inland Steel 275 N.L.R.B. at 936 (no duty to bargain about relocation decision). Compare Brown Co., 278 N.L.R.B. No. 113 (1986) (imposing duty to bargain because company transferred all the work of one job classification "for the sole purpose of escaping from its wage obligations under the existing collective-bargaining contract").

${ }^{87}$ Because the employer's motive has become a central issue in deciding duty to bargain cases, $\S 8(\mathrm{a})(5)$ discussions have sometimes been collapsed into $\$ 8(a)(3)$ inquiries, where the employer's motive has traditionally has been the dispositive consideration. Thus, for example, in Lear Siegler, Inc., 277 N.L.R.B. 782 (1985), the NLRB found a §8(a)(5) violation because the employer's motive in transferring work from one facility to another was to avoid the union. In Weather Tamer, Inc. v. N.L.R.B., 676 F.2d 483 (11th Cir. 1982), the court found that a company that closed a plant at the same time a union was certified there did not violate $\S 8(\mathrm{a})(5)$ because there was no violation of $\S 8(\mathrm{a})(3)$. In so linking the two provisions, the court quoted dictum in the First National Maintenance opinion that "the union's legitimate interest in fair dealings is protected by $\$ 8(\mathrm{a})(3) . "$ Id. at 493 , quoting First National Maintenance, 452 U.S. at 682.

88 Inland Steel, 275 N.L.R.B. at 929.

89 Id. at 936.

${ }^{\circ 0}$ Id. at 929 . 
Any decision motivated by a concern for overall profitability, or any decision that can be justified from the standpoint of profitability, is exempt from the bargaining obligation. Employers can easily characterize any decision in that way. ${ }^{91}$ This new approach narrows the range of mandatory bargaining even further than did First $\mathrm{Na}$ tional Maintenance. The realm of mandatory bargaining has gotten very small and no longer encompasses most of the decisions that unions need to influence.

\section{B. Investment Decisions Under $§ 8(a)(3)$}

Section 8(a)(3) makes it unlawful for an employer to discriminate on the basis of union activity. ${ }^{92}$ While $\S 8(\mathrm{a})(5)$ requires that an employer bargain over certain decisions, and refrain from altering the status quo until that obligation has been met, §8(a)(3) says certain decisions may not be implemented at all. Thus it is a potentially serious limitation on employer freedom of action.

The prevailing interpretation of $\S 8(\mathrm{a})(3)$ is that it prohibits an employer from taking actions that adversely affect its employees if those actions are motivated by anti-union sentiments. ${ }^{93}$ Employer investment and production decisions and corporate transformations that result in the elimination of many jobs or entire bargaining units obviously have an adverse effect on employees. If such decisions are motivated by anti-union sentiments, the decisions violate $\S 8(a)(3) . .^{94}$ For unions seeking to protect jobs in the face of such employer actions, the important question is whether action motivated by a desire to escape the economic consequences of a union is to be considered "motivated" by anti-union sentiments, and hence unlawful. ${ }^{98}$

The NLRB originally held that an employer action that was motivated by a desire to avoid paying a union wage or to avoid the other economic consequences of a union was "motivated by anti-

91 See, e.g., Garwood-Detroit Truck Equipment Inc., 274 N.L.R.B. 113, 114-15 (1985), in which an employer's decision to subcontract all the bargaining unit work, clearly motivated by a desire to reduce labor costs, was characterized by the NLRB as a decision to reduce overhead costs and thus not subject to mandatory bargaining.

${ }^{82}$ See note 41 .

${ }^{93}$ See note 41. But see Christensen and Svanoe, 77 Yale L.J. at 1278 (cited in note 41) (in the original interpretation of $\$ 8(a)(3)$ violations could be found in the absence of a finding as to anti-union motivation).

24 Textile Workers v. Darlington Co., 380 U.S. at 276 (1965).

${ }^{95}$ See Getman, 32 U.Chi.L.Rev. at 738-9 and n.14 (cited in note 41) (difficult to distinguish valid business considerations from anti-union motivations in the case of employer production and investment decisions). 
union sentiment" and hence was a violation..$^{96}$ However, that position did not prevail. Instead the courts insisted that the type of anti-union motive necessary to establish a violation of $\S 8(a) 3$, at least in a corporate transformation, was some other kind of antiunionism. For example, in N.L.R.B. v. Adkins Transfer Co. ${ }^{97}$ one of the first $\S 8(\mathrm{a})(3)$ cases concerning a corporate transformation, the NLRB found that the employer violated §8(a)(3) by closing its maintenance department as soon as the maintenance employees joined a union and demanded that the employer pay the standard union wage scale. ${ }^{98}$ This type of economically based anti-unionism was sufficient to make out a violation. However, the court of appeals refused to enforce the NLRB order because, it said, the NLRB was incorrect in finding this action to be a discrimination on the basis of union activity. Rather, the court said that the "real reason" for the employer's decision was that the union wage scale was too high for the employer to operate profitably, not that the employer was hostile to the union. ${ }^{89}$

A similar result obtained in Rapid Bindery Inc. v. N.L.R.B., ${ }^{100}$ a case in which an employer closed down its plant and relocated as soon as its employees unionized. The NLRB examiner found that the employer's decision was made "in an atmosphere redolent with hostility toward the Union, and for the purpose of discouraging membership in it," and thus violated §8(a)(3). ${ }^{101}$ The Second Circuit refused to enforce the NLRB order because it found the employer's motivation was economic. ${ }^{102}$

These two appellate cases typify the position of the courts on the application of $\S 8(\mathrm{a})(3)$ to corporate investment and production

${ }^{96}$ See Adkins Transfer Co., 109 N.L.R.B. 956 (1954); Tennessee-Carolina Transportation Co., 108 N.L.R.B. 1369 (1954); J.M. Lassing et.al., 126 N.L.R.B. 1041 (1960). See also N.L.R.B. v. Star Publishing Co., 97 F.2d 465, 470 (9th Cir. 1938) ("[NLRA] permits no immunity because the employer may think that the exigencies of the moment require infraction of the statute").

${ }^{97} 226$ F.2d 324 (6th Cir. 1955).

${ }^{28}$ Adkins Transfer Co., 109 N.L.R.B. 956 (1954).

"226 F.2d at 328 . The court pointed to a long history of amicable relations between the employer and a union that represented other employees. It concluded that the employer's decision was not motivated by anti-union sentiment, but rather the employer believed it could not pay union wages and still operate profitably. The court said $\S 8(a)(3)$ did not prohibit this motive. Id. at 329 .

While the court's reasoning suggested that the decision turned on the absence of employer hostility to unions, subsequent cases made it clear that the operative factor was not the presence or absence of hostility.

${ }_{100} 293$ F.2d 170, 172 (2d Cir. 1961).

201 Id. at 174-75.

102 Id. 
decisions that eliminate jobs. ${ }^{103}$ Almost from the outset, courts were not willing to find a violation of $\S 8(a)(3)$ when an employer had taken an action for the purpose of avoiding the economic consequences of a union. ${ }^{104}$ Rather, it was held that the provision only prohibited employer decisions based on irrational anti-unionism, not those based on economically rational anti-unionism. ${ }^{105}$

For almost thirty years, the distinction between rational antiunionism ("economic motivation") and irrational anti-unionism ("animus") determined the application of §8(a)(3) to employer investment decisions. ${ }^{106}$ In cases where both rational and irrational motivations were present, the NLRB and the courts muddled through. ${ }^{107}$ Recently, however, the NLRB's treatment of $\S 8(a)(3)$

${ }^{103}$ See, e.g., Weather Tamer, Inc., 676 F.2d at 492-93 (closing plant just as union was certified is not a violation of $\S 8(a)(3)$ because there was evidence that decision was motivated by economic conditions); N.L.R.B. v. Dale Industries, Inc., 355 F.2d 851, 854 (6th Cir. 1966) (curtailment or suspension of operations motivated by economic reasons is not an unfair labor practice); N.L.R.B. v. Kelly \& Picerne, Inc., 298 F.2d 895, 899 (1st Cir. 1962) (employer can subcontract in the face of a union drive so long as it does so "in the exercise of a purely business judgment"); N.L.R.B. v. Lassing, 284 F.2d 781, 783 (6th Cir. 1960) (no violation where employer responded to anticipated increase in costs, notwithstanding whether the increase resulted from the advent of a union or some other factor).

104 See Getman, 32 U.Chi.L.Rev at 738-39 and n.14 (cited in note 41) (finding this approach "unfortunate" because "[a]lmost any conduct which penalizes employees for union membership or activity can be described in other [economically rational] terms").

The same approach is not used for those §8(a)(3) cases in which a union activist is fired for trying to organize a union. In those cases, the employer often is "motivated" by a desire to keep out the union, so as to avoid paying the union wage scale or being subjected to union work rules. During organizational campaigns, this anti-union motive is precisely the type of motive that the NLRB looks for to find a violation. See, e.g., Jenks Cartage Co., 219 N.L.R.B. 368, 369-70 (1975); East Bay Newspapers, Inc., 228 N.L.R.B. 692, 703 (1977).

${ }^{105}$ The Supreme Court affirmed this doctrine in passing in Textile Workers v. Darlington Co., 380 U.S. 263, when it held that a company may have violated $\$ 8(a)(3)$ when it shut down one of its plants as a result of a successful union organizing drive. The Court said that, while the NLRA does not prevent an employer from going out of business altogether for anti-union reasons, 380 U.S. at 273-74, the NLRA does prohibit intentional employer actions designed to chill the exercise of employees' right to organize. Id. at 275. It distinguished decisions that are economically motivated from those motivated by an employer's anti-unionism. Thus, it remanded the case to the NLRB to determine whether the employer action was motivated by a desire to discourage unionization at its other remaining plants, with instructions that if such a motive were found, there would be a violation.

${ }^{108}$ The distinction may seem a little silly because it is quite obvious that most employer opposition to unions is economically based. However, where the employer's economic rationale is facially specious, the courts have found violations. See, e.g., Local 57, Int'l Ladies Garment Workers Union v. N.L.R.B., 374 F.2d 295 (D.C.Cir. 1967), where an employer of a runaway shop conceded that it had anti-union sentiment, but also claimed that the decision to move was economically motivated. The court rejected this claim because it found that the employer was making substantial profits prior to the decision to move. Id. at 299.

${ }^{107}$ The NLRB has taken differing approaches to mixed-motive cases. Compare Dow Chemical Co., 13 N.L.R.B. 993, 1023 (1939) enf'd in relevant part, 117 F.2d 455 (6th Cir. 1941) (holding that if any part of the employer's motivation is anti-union, there is a viola- 
cases has undergone a subtle yet significant shift. The NLRB has begun to dispense with the motive inquiry altogether and has substituted an inquiry into the employer's justification for its decision. The significance of this shift is that while "motive" looks to the before-the-fact reasons for a decision, "justification" can mean an after-the-fact rationale for it. This last development immunizes almost all employer production and investment decisions from $\S 8(\mathrm{a})(3)$ attack.

The line of cases leading to the substitution of justification for motive began with the Supreme Court decision in N.L.R.B. v. Great Dane Trailers, Inc. ${ }^{108}$ The Court stated that a $\$ 8(a)(3)$ violation could be found without an explicit finding of any anti-union motive. The Court set out the standard and sequence of proof for establishing \$8(a)(3) violations and said that, for those types of employer actions that were "inherently destructive of important employee rights," a violation can be found without a showing of any anti-union motivation. ${ }^{109}$ In such a case, however, if an employer offers a business "justification" for its actions, then the NLRB must balance the justification against the destructive impact of the employer's conduct on employee rights. ${ }^{110}$ For other employer actions whose impact on employee rights is "relatively slight," the employer's conduct is prima facie lawful if a "legitimate business end" is served. In those cases, a violation would be found only if improper motivation is shown. ${ }^{111}$ Thus for the second category of cases, the employer's economic justification is a defense that will prevail unless the union can prove anti-union motivation. Stated differently, once the employer has introduced evidence of its business justification for the action, the charging party needs to prove that the employer acted out of an anti-union motive.

The Great Dane rules for establishing $§ 8(a)(3)$ violations focused attention on the employer's business justification for its action. The rule regarding "inherently destructive" actions was beneficial to unions because it provided a means of establishing a per se

tion) with Robbins Tire \& Rubber Co., 69 N.L.R.B. 440, 454 n.21 (1946), enf'd 161 F.2d 798 (5th Cir. 1947) (no violation if employer can show that it would have taken the challenged action even in the absence of the discriminatory motivation).

${ }^{103} 388$ U.S. 26 (1967).

${ }^{109}$ It gave as its example, N.L.R.B. v. Erie Resistor Corp., 373 U.S. 221 (1963), which held that an employer's grant of superseniority for strikebreakers was inherently destructive of important employee rights, and thus a violation of $\S 8(a)(3)$. Great Dane, 388 U.S. at 3334.

${ }^{110} 388$ U.S. at $33-34$.

111 Id. at 34. 
violation of $\S 8(\mathrm{a})(3)$ without a showing of anti-union motive. ${ }^{112}$ However, in both categories, the Great Dane analysis brought the question of the employer's justification-the objective reasonableness of its actions-into the case. ${ }^{113}$

Subsequently, in the Wright Line case, ${ }^{114}$ the NLRB further shifted its focus from motive to justification in the $\$ 8(a)(3)$ context. The employer in Wright Line allegedly acted with mixed motives, some lawful and some unlawful. In deciding how to deal with such mixed-motive situations, the NLRB again addressed the issue of how $\S 8(a)(3)$ violations must be proven. It said that the charging party must make out a prima facie case of unlawful motivation. The employer can then rebut this case by showing a "legitimate business reason" for its action such that the action would have been taken with or without the unlawful motivation. ${ }^{115}$ In 1983, the Supreme Court approved the NLRB's adoption of the Wright Line test in N.L.R.B. v. Transportation Management Corp. ${ }^{116}$

This shift in focus from motive to justification, or "legitimate business reasons," as an affirmative defense, means that an employer can introduce evidence of its business justification to defend against a $\S 8(\mathrm{a})(3)$ charge. Business justification takes the trier of fact out of the hazy world of motive into the clear light of business rationality. It makes it possible for an anti-union action to escape sanction so long as it can be "justified," even if justified after the fact. ${ }^{117}$

112 The NLRB and courts have almost never found employer decisions to automate, relocate, merge, or subcontract to be "inherently destructive" of employee rights, and hence a per se violation. See, e.g., Griffith-Hope Co., 275 N.L.R.B. 487 (1985), where the employer subcontracted out all the bargaining unit work because the union scale was too expensive, and then offered to recall employees if they would agree to a 50 percent wage reduction. The NLRB found no violation of $\S 8(a)(3)$ because it said the behavior was neither inherently destructive nor motivated by anti-union sentiment. See also N.L.R.B. v. National Car Rental Systems, Inc., 672 F.2d 1182 (3d Cir. 1982) where a trucking company sold its leasing operation at one facility and transferred some non-union employees to another facility that it operated nearby. It refused to transfer any of the employees who were represented by the union because it said it did not want the union at the other facility. The NLRB found a $\S 8(a)(3)$ violation on the grounds that the employer behavior was inherently destructive under Great Dane. The Third Circuit affirmed the decision, but rejected the NLRB's finding that the behavior was inherently destructive. Instead it based its decision on the existence of anti-union motive. Id. at 1187.

11s See Harlan's dissent in Great Dane arguing that the Court's decision invites the NLRB to balance the employer's business purpose with the harm to union interests. 388 U.S. at 39.

314251 N.L.R.B. 1083 (1980), enf'd, 662 F.2d 899 (1st Cir. 1981).

115 Id. at 1088.

116462 U.S. 393 (1983).

${ }^{117}$ See, e.g., Aviex Corp., 279 N.L.R.B. No. 110 (1986) (finding valid business justifica- 
Subsequent cases have indeed shown that employer actions that can be economically justified post hoc are immune from §8(a)(3) attack, notwithstanding the presence of explicit antiunionism. For example, in Handy Andy Associates, Inc., ${ }^{118}$ an employer told its employees that if they did not abandon their union, he would subcontract their work and lay them off. The employees refused to yield to the threat, so the employer subcontracted the work. Nonetheless, the NLRB found no §8(a)(3) violation because it found that the decision was based on "legitimate economic reasons." The evidence that outside deliverymen could perform the work at one-half the cost of the union wage scale ${ }^{119}$ was developed after the fact. No effort was made to show that those economic considerations were the basis of the employer's decision.

The recent trend blurring the distinction between motive and justification is relevant in cases where an employer has taken an action, such as relocating or subcontracting, to avoid paying a union wage. The new doctrine makes it easier than before for an employer to act with impunity because, however motivated, any business decision that replaces union labor with nonunion labor will almost always make economic sense, and therefore be "justified" in a Great Dane-Wright Line sense. The new approach creates the possibility that an after-the-fact justification for any action will effectively immunize it from \$8(a)(3) attack. In fact, when employers make investment and production decisions to evade the economic consequences of unionism, the business justification is always, and automatically, present.

Further, it is possible to interpret this shift from motive to justification as more than the abandonment of the traditional motive requirement for $\S 8(\mathrm{a})(3)$ cases. That is, the NLRB may be imputing to an employer a legitimate business motive for any action which it finds to be "justified" after the fact. If so, it is introducing a myth, or an unstated presumption, that reasonable employers make reasonable business judgments. ${ }^{120}$ Armed with this presump-

tion for layoff of entire workforce which occurred just after employer notified of union organizing drive); cf., Service Merchandise Co., 278 N.L.R.B. No. 23 (1986) (rejecting company's claim that it had subcontracted its work for economic reasons because, after the change, the company's costs went up 25 percent).

118277 N.L.R.B. 208 (1985).

129 Id. at 216.

${ }^{120}$ The Supreme Court recently imposed a similar presumption of business rationality in the antitrust context in Matsushita Elec. Indus. Co. v. Zenith Radio, 106 S.Ct. 1348, 1356 (1986) (antitrust violation is sustained only if a rational business justification can be shown for defendant to engage in anti-competitive behavior). 
tion, the NLRB can thus conclude that any employer action that can be justified in a business sense must have been motivated by legitimate business considerations. ${ }^{121}$ By so doing, the NLRB can avoid the quest for determining actual motive altogether.

If the new direction in §8(a)(3) cases does indeed embody such a concept of imputed motive, then little is left of the protection of that provision, at least for the decisions that eliminate jobs. The concept of imputed motive represents total deference to an employer's market-based business judgments and makes all such decisions invulnerable to $\S 8(a)(3)$ attack.

\section{The Concept of Successorship}

There are several labor law doctrines that the govern the labor obligations of corporate entities after mergers, purchases of assets of other corporations, or similar corporate transformations. In particular, distinct doctrinal frameworks govern the survival of the following different labor obligations: The obligation to continue to recognize and bargain with the predecessor's union, the obligation to honor the substantive terms of the predecessor's collective bargaining agreement, the obligation to honor the predecessor's contractual promise to arbitrate disputes, and the obligation to absorb liability for the predecessor's unfair labor practices. ${ }^{122}$

Many scholars believe that the precise rules and criteria for determining successor status have implications for how the law promotes or discourages capital mobility. To this effect, different

122 The myth that reasonable businesspeople make reasonable business judgments is found in much microeconomic thought. See, e.g., Mansfield, Economics at 141-44 (cited in note 82) (on assumption of rationality and profit-maximization).

122 As the Supreme Court said in Howard Johnson Co. v. Hotel Employees, 417 U.S. 249, 262-263 \& n. 9 (1974) ("Howard Johnson's"):

[T] he real question in each of these 'successorship' cases is, on the particular facts, what are the legal obligations of the new employer to the employees of the former owner or their representative? The answer to this inquiry requires analysis of the interests of the new employer and the employees and of the policies of the labor laws in light of the facts of each case and the particular legal obligation which is at issue. . There is, and can be, no single definition of 'successor' which is applicable in every legal context.

See generally Jonathan F. Silver, Reflections on the Obligations of a Successor Employer, 2 Cardozo L.Rev. 545, 557 (1981) (courts have not been sufficiently sensitive to different issues raised by the differing types of successorship questions).

There is also an issue of a successor's liability for its predecessor's violations of other federal and state labor relations statutes, such as Title VII of the Civil Rights Act and federal and state wage and hour statutes. These successorship questions tend to be decided under the same criteria that are applied to those involving liability for a predecessor's unfair labor practices. Claiborne Barksdale, Successor Liability Under the N.L.R.A. and Title VII, 54 Tex.L.Rev. 707, 725 (1976). 
scholars have made varying assumptions about the impact of successorship doctrines on capital mobility, and have expressed differing points of view about the desirability of different forms of capital mobility, thereby reaching varying conclusions about what mix of types of successor liability is optimal. ${ }^{123}$ Some claim that imposing successor obligations frequently will hamper capital mobility by discouraging takeovers and buyouts and by saddling purchasers with large costs. ${ }^{124}$ Some have argued that such obligations involve not only significant costs, but also costs that frequently cannot be known at the time of a purchase, and thus cannot be figured into the cost equation when making the initial purchase decision. ${ }^{125}$ Others claim that successorship obligations have little or no impact on capital mobility because successors can always protect themselves by obtaining indemnification agreements as part of their purchase agreements. ${ }^{126}$ Furthermore, some have argued that by not imposing a successorship obligation at least to recognize the union, if not to continue the terms of the collective agreement, the law encourages those corporate transformations undertaken in or-

${ }^{123}$ See, e.g., Charles J. Morris and William Gaus, Successorship and the Collective Bargaining Agreement: Accommodating Wiley and Burns, 59 Va.L.Rev. 1359, 1384-85 (1973) (arguing that to impose terms of predecessor's collective agreement on successor would restrict successor too much, but to require arbitration would not); Charles G. Bakaly, Jr. and James S. Bryan, Survival of the Bargaining Agreement: The Effect of Burns, 27 Vand.L.Rev. 117, 128-129 (1974) ("common sense and practical experience" suggest that imposing duty of successor to honor or arbitrate terms of predecessor's collective agreement will restrict transfer of capital); Stephen B. Goldberg, The Labor Law Obligations of A Successor Employer, 63 Nw.U.L.Rev. 735, 748 (1969) (imposition of a duty to arbitrate when there is substantial continuity of identity between a successor and a predecessor gives adequate protection to the employer's interests in free transferability of productive assets). But see Eileen Silverstein, The Fate of Workers in Successor Firms: Does Law Tame the Market?, 8 Ind.Rel.L.J. 153, 173 (1986) (empirical evidence does not show that labor obligations play any significant role in corporate acquisition decisions).

124 See Bakaly and Bryan, 27 Vand.L.Rev. 117 (cited in note 123). See also N.L.R.B. v. Burns Security Services, 406 U.S. 272, 288 (1972) (saddling successor with predecessor's collective bargaining agreement may discourage or inhibit transfer of capital).

${ }^{225}$ See, e.g., Lawrence F. Doppelt, Successor Companies: The N.L.R.B. Limits The Options-And Raises Some Problems, 20 DePaul L.Rev. 176, 191 (1971) ("[A] successor may well acquire more liabilities ... than appear on the face of a contract."). The majority opinion in Burns cites the Doppelt article to support its argument that imposition of the terms of a collective agreement may saddle the successor with unknown preexisting obligations. 406 U.S. at 290.

${ }^{128}$ See, e.g., Note, Independent Purchaser Held Responsible for Remedying Predecessor's Unfair Labor Practices, 42 N.Y.U.L.Rev. 1202, 1205 and 1207 (1967) (should hold successors responsible for unfair labor practices of predecessors, even in the absence of actual knowledge, because of the possibility of indemnification); Note, Purchaser's Liability for Predecessor's Unfair Practices, Duty to Reinstate With Back Pay 13 Vill.L.Rev. 232, 237 (1967). 
der to get rid of labor obligations. ${ }^{127}$

Without denying the importance of successorship rules for capital mobility, the question for my purposes is somewhat more narrow. The question to be addressed here is what these various successorship doctrines can tell us about the possibilities for an expanded role for labor in the corporate structure. This is a question that perhaps is best approached by backing into it. If there were a strong successorship doctrine, encompassing not just the survival of the bargaining obligation but also the survival of the substantive terms of the preexisting collective agreement, unions would not necessarily have a greater role in corporate decision making, but neither would they be so vulnerable to corporate transformations as they are at present. That is, the successorship doctrines do not directly affect union involvement in corporate decision making, but they do specify the degree to which unions will be hurt by corporate transformations. In fact, if unions and their collectively bargained agreements always survived corporate transformations, then unions might not care particularly whether the transformations occurred. To the extent that they cared, unions might support those transformations that offered the prospect of making management more efficient and the operation more profitable, so long as there were not job losses involved. That is, such a doctrine might lead to a greater congruity of interests between management and labor, and thus help foster a more truly cooperative labor-management relationship.

Furthermore, a strong successorship doctrine might indirectly lead to a greater role for labor in corporate decision making. If the union and the collective bargaining agreement automatically survived a corporate transformation by operation of law, then whenever a corporation wanted to make a deal that entailed altering the composition of the work force or other terms and conditions of employment, it would have to obtain the union's consent. In fact, under present doctrine, it would probably need the union's prior approval-assuming that the issues to be altered were mandatory subjects of bargaining. ${ }^{128}$ Thus the union would have to be brought

${ }^{127}$ See Sarah Siskind, Employer Instability and Union Decline, in R. Adelman, ed., Proceedings of the N.Y.U. 39th Ann. Conf. on Labor, 8-1, 8-9 (1986) (comparing employer's ability to evade its labor obligations in successor situation with Chapter 11 bankruptcy proceedings).

${ }^{128} \mathrm{Katz}, 369$ U.S. 736 (employer cannot make a unilateral change in a mandatory subject of bargaining without first bargaining in good faith). But see Milwaukee Spring (II), 268 N.L.R.B. 601 (after bargaining to impasse, employer can institute mid-term modification unilaterally unless term to be modified is explicitly set out in the collective agreement). 
in before the decision was made. The union, in bargaining over management's requested concession, would have the opportunity to discuss the desirabilty of the decision and, possibly, to affect its course. Thus, a strong successorship doctrine would give an employer an incentive to include unions in corporate decision making about such transformations. ${ }^{129}$ In cases of financially troubled corporations, such a doctrine might give them an incentive to consult with unions about overall profitability prior to considering something so drastic as a total transformation. ${ }^{130}$

Existing successorship law, however, does not provide management much incentive to include unions in their corporate decision making. In this area, as in the $\S 8(a)(3)$ and $\S 8(a)(5)$ areas discussed above, the labor laws neither prevent those corporate transformations which are undertaken to avoid a union nor give the union a voice in the decisions. But, as in the other areas of the law discussed above, there are precedents in the successorship area which could be extended to give the law that potential.

In a well-known trio of cases spanning ten years, the Supreme Court set out the contours of the current successorship doctrine. The first of the cases, John Wiley \& Sons $v$. Livingston, ${ }^{131}$ dealt with a situation in which a small company was bought by, and merged into, a larger concern. The union that had represented employees at the predecessor wanted to arbitrate the question of the continuing application of its collective bargaining agreement to the members of the bargaining unit for the time period from the merger until the expiration of agreement. The Supreme Court said arbitration was required because there was substantial continuity in the operation despite the change of ownership. ${ }^{132}$

129 See Morris and Gaus, 59 Va.L.Rev. at 1385 (cited in note 123) (suggesting that to impose obligations on the successor to arbitrate under the terms of the predecessor's collective agreement would permit prospective purchasers to bargain with the union beforehand for concessions).

${ }^{130}$ A strong successorship doctrine would give the union leverage against both the existing employer and any potential purchaser. It would operate in a similar fashion to the status quo provisions of the Railway Labor Act, which require carriers to refrain from making major changes in working conditions and to maintain the status quo until the obligation to bargain with the union has been satisfied. 45 U.S.C. $\$ 156$. See, Order of Railroad Telegraphers v. Chicago \& N.W.Ry. Co., 362 U.S. 330 (1960) (employer violated status quo provision by closing down some of its operations before bargaining with union, notwithstanding employer's assertion of financial exigencies). See generally Shore Line v. Transportation Union, 396 U.S. 142, 150 (1969) (purpose of requiring employer to preserve status quo prior to implementing decision is to give union opportunity to influence decision or extract some other concession in return for permitting the decision to go forward).

131376 U.S. 543 (1964).

132 Id. at 551. 
In the second of the trio, N.L.R.B. v. Burns Int'l Security Services, Inc. ${ }^{133}$ Lockheed Aircraft hired the Burns Security Service to replace another company that had performed the same security work. The union that had represented the employees of the former security company sought to bind Burns to the terms of its collective bargaining agreement and to require Burns to recognize it. The Supreme Court held that Burns, the successor employer, was required to recognize and bargain with its predecessor's union because it had hired a majority of the former's employees and because there was substantial continuity between the two operations. ${ }^{134}$ However, it also said that there was no obligation on the part of the new employer to abide by the terms of the predecessor's collective bargaining agreement. ${ }^{135}$

In the last case of the trio, Howard Johnson Co. v. Detroit Local Joint Exec. Board, ${ }^{136}$ the Supreme Court retreated from its position in Wiley and said that, in most cases of corporate transformation, the duty to arbitrate does not survive. ${ }^{132}$ In that case, an employer sold its assets to another company, and the union that represented the employees of the predecessor sought to arbitrate the question of the extent of the successor's obligations to the predecessor's employees after the sale. The court refused to order arbitration. It distinguished Wiley on the ground that in this case there was no substantial continuity of the workforce because only a few of the former employees were retained by the successor. ${ }^{138} \mathrm{Fur}$ thermore, it said, in Wiley there was a merger, and thus there was no surviving entity against which the union could assert its demands, whereas here there was only a sale and rental of assets, so that there remained an entity from which the union could seek relief. ${ }^{138}$

From these cases, the following principles of successorship can be discerned. First, a successor must bargain with its predecessor's union if it retains a majority of the former's employees and if there

\footnotetext{
133406 U.S. 272 (1972).

134 Id. at $280-81$.

135 Id. at 281-84.

138417 U.S. 249 (1974).

137 Id. at $262-63$.

${ }^{238}$ Id. at 258-61.
}

139 Id. at 257. The court's reliance on a lack of continuity of employees is somewhat circular in Howard Johnson's because the reason that the union sought arbitration was to force the new employer to retain all the former employees except those who could be discharged for "just cause" under the agreement. Id. at 260. The Court used the very fact that the union was litigating--the failure of the new employer to retain the former employees-as its reason for denying it relief. 
is substantial continuity between the operations. ${ }^{140}$ Second, a successor is not bound by its predecessor's collective agreement unless it implicitly or explicitly assumed it. ${ }^{141}$ And, as for the duty to arbitrate under the former agreement, as one commentator has stated, it remains "shrouded in mystery."142

Yet another kind of successorship which arises in the labor law context is unfair labor practice successorship-i.e., the conditions under which a successor will be liable for its predecessor's unfair labor practices. The imposition of this type of successor liability depends more on concepts of agency and consent than do the other forms of successor obligations. ${ }^{143}$ In Golden State Bottling Co. $v$. N.L.R.B. ${ }^{144}$ the Supreme Court said that to impose successor liability for unfair labor practices there must be substantial continuity in the business and workforce and actual or constructive notice to the subsequent employer of the existence of the unfair labor practices against the predecessor. ${ }^{145}$ The notice requirement suggests that the courts presume that a purchaser who knows of the predecessor's liability, and purchases in the face of it, has consented to assume the liability. ${ }^{146}$ That is, this form of successorship obligation depends on finding an explicit or implicit assumption of responsibility on the part of the successor. ${ }^{147}$

${ }^{160}$ See Fall River Dyeing \& Finishing Corp. v. N.L.R.B., 107 S.Ct. 2225, 2236-37 (1987) (on meaning of "substantial continuity"); Silver, 2 Cardozo L.Rev. at 558-573 (cited in note 122) (discussing successor's duty to bargain).

${ }^{141}$ The NLRB engages in a fact-specific inquiry to determine whether there has been an agreement by a Burns successor to assume its predecessor's collective agreement. See, e.g., N.L.R.B. v. World Evangelism, Inc., 656 F.2d 1349 (9th Cir. 1981).

${ }^{142}$ Barksdale, 54 Tex.L.Rev. at 711 (cited in note 122). If the duty to arbitrate survived, then arguably the terms of the agreement would also survive, because the arbitrator would have the authority to impose them. But see, Siskind, 39th Ann. N.Y.U. Conf. on Labor at 816 (cited in note 127) (arguing that Wiley still has force even after Howard Johnson's and that it requires a successor to arbitrate contractual claims if there is substantial continuity of the work force).

${ }^{143}$ Frederick K. Slicker, Reconsideration of the Doctrine of Employer Successorship: A Step Toward a Rational Approach, 57 Minn.L.Rev. 1051, 1072-73 (1973) (noting different rationale for unfair labor practice successorship than for bargaining unit successorship).

${ }^{144} 414$ U.S. 168 (1973).

${ }^{146}$ Id. at $172-73$.

146 See N.L.R.B. v. Fabsteel Co. of Louisiana, 587 F.2d 689 (5th Cir. 1979) (imposing unfair labor practice successorship because successor had knowledge of NLRB order against predecessor). There need not be actual consent, or even actual knowledge, of the existence of the unfair labor practice for courts to impose unfair labor practice successorship. It is sufficient that a prospective purchaser have notice of some of the facts on which the later finding of an unfair labor practice is based. N.L.R.B. v. Jarm Enterprises, Inc., 785 F.2d 195, 202 (7th Cir. 1986).

147 In addition, successor liability for unfair labor practices will be imposed when two entities are found to be "alter egos" or a "single employer" for purposes of the NLRA. 
The types of successorship that are most important for unions faced with corporate transformations are those that involve continuation of the bargaining unit and continuation of the collective bargaining agreement. Since the decision in Burns, the imposition of bargaining obligations on successors occurs by operation of law once a successor has hired a "representative complement" of its workforce, so long as a majority of the successor's employees were employees of the predecessor and so long as there is substantial continuity between the two operations. ${ }^{148}$ Some, including Justice Douglas in his dissent in Howard Johnson's, have objected to this rule because it enables the successor to determine whether or not to be subject to the bargaining obligation by deciding whether or not to hire a majority of the former employees. ${ }^{149}$ Others argue that this rule gives successors a disincentive to retain former employees. ${ }^{180}$ Although this successorship rule seems like a readymade device for employers to evade bargaining obligations, ${ }^{151}$ in practice, a surprising number of subsequent employers do choose to retain a majority of their predecessor's workforce. ${ }^{152}$ This seeming anomaly might reflect the fact that in many situations, a purchaser values an experienced workforce more than it values avoid-

Hopwood Retinning Co., 4 N.L.R.B. 922 (1938), modf'd, 98 F.2d 97 (2d Cir. 1938). These doctrines are discussed below.

148 Fall River Dyeing, 107 S.Ct. 2225; Spruce-Up Corp. 209 N.L.R.B. 194 (1974), enf’d 529 F.2d 516 (4th Cir. 1975); Saks \& Co. v. N.L.R.B., 634 F.2d 681 (2d Cir. 1980).

149 Justice Douglas, dissenting in Howard Johnson's, called the reasoning of the majority "nonsense." 417 U.S. at 268. He argued that the decision would permit any new employer "to determine for himself whether he will be bound [by the predecessor's collective agreement] by the simple expedient of arranging for the termination of all of the prior employer's personnel." Id. at 269. Other scholars have also found this aspect of the Burns and Howard Johnson's decisions to be "peculiar." Note, The Supreme Court, The 1973 Term, 88 Harv.L.Rev. 41, 269-70 (1974). See also James Severson and Michael Willcoxon, Successorship Under Howard Johnson: Short Order Justice for Employees, 64 Calif.L.Rev. 795 (1976) (criticizing Howard Johnson's for allowing successor employers to determine unilaterally their labor obligations by deciding how many incumbents to retain). But see Silverstein, 8 Ind.Rel.L.J. at 161 (cited in note 123) (finding this result a rational way for the court to permit market factors to govern).

150 Note, 88 Harv.L.Rev. at 269-70.

151 But see, Fall River Dyeing, 107 S.Ct. at 2234 (NLRB's successorship rules designed to prevent employers from using successor enterprise to rid itself of a labor contract or to undermine a union).

${ }^{152}$ See, e.g., Matlack, Inc., 278 N.L.R.B. No. 36 (1986) (eighteen out of twenty-one incumbent employees retained by successor employer); Teamsters (Anheuser-Busch) 277 N.L.R.B. 1097 (1986) (twelve of sixteen incumbent employees retained by successor employer); Great Lakes Chemical Corp., 280 N.L.R.B. No. 66 (1986) (thirty-six out of fortyfour incumbent employees retained by successor employer); Advice Memorandum of N.L.R.B. General Counsel regarding General Electric Co./Powerex, Inc., 122 L.R.R.M. 1363, 1365 (1986) (finding successorship, in part, because all former employees retained). 
ing a union, at least where an organizing drive for a new union seems likely to occur anyway. ${ }^{\mathbf{1 5 3}}$

The obligation of a successor to honor its predecessor's collective bargaining agreement is the more important form of successorship from the point of view of protection against corporate transformation. Since the decisions in Burns and Howard Johnson's, it has been settled that a finding of bargaining unit successorship does not mean that a subsequent entity must honor the terms of the collective bargaining agreement of its predecessor, whether those claims are asserted in an unfair labor practice or an arbitration context. ${ }^{154}$ This form of successorship obligation is imposed only where the two employers are found to be a "single employer" or to be "alter egos" of each other. If they are either, then the collective bargaining agreement survives.

The single employer doctrine is a NLRB-created doctrine which says that two different employing entities can have joint control over a single bargaining unit such that they become a "single employer" for all purposes of the labor laws. In such a situation, each bears responsibility for the other's labor obligations, including obligations to bargain with a certified union, abide by a collective agreement, and redress any unfair labor practice violations. Once single employer status is determined, the two entities are, for purposes of the NLRA, deemed to be the same. ${ }^{155}$

While the single employer doctrine provides unions some protection in some situations, its usefulness is limited to cases where

15s See Fall River Dyeing, 107 S.Ct. at 2225, where the Supreme Court said:

Thus, to a substantial extent the applicability of Burns rests in the hands of the successor. . . . This makes sense when one considers that the employer intends to take advantage of the trained work force of its predecessor.

(emphasis in original). See also Silverstein, 8 Ind.L.Rel.L.J. at 172 (cited in note 123) (successorship rules ratify the economic arrangements preferred by successors).

154 There is a possible exception for a merger, like the one in Wiley, in which the predecessor no longer exists. The continuing viability of this narrow exception is unclear. See Siskind, 39th Ann.N.Y.U. Conf. on Labor at 8-16 (cited in note 127) (arguing that Wiley has continuing viability).

183 N.L.R.B. v. Browning-Ferris Industries, Inc., 691 F.2d 1117, 1122 (3rd Cir. 1982). See Hahn Motor, Inc., 283 N.L.R.B. No. 141 (1987) (finding single employer status).

To determine single employer status, the NLRB looks to the degree of functional integration between two separate concerns to determine whether they actually constitute one bargaining unit. It uses a four factor test: Degree of interrelation of operations, centralized control of labor relations, common management, and common ownership or financial control. See Radio Union v. Broadcast Service of Mobile, Inc., 380 U.S. 255, 256 (1965) (listing factors for finding two employers to be "single employer"); Parklane Hosiery Co., 203 N.L.R.B. 597, 612 (1973) (listing factors). No single factor is dispositive. See generally, Note, Bargaining Obligations After Corporate Transformation, 54 N.Y.U.L.Rev. 624, 631-638 (1979) (discussing single employer doctrine). 
there are two entities. In most cases involving corporate transformations, a single entity is transformed into another single entity, although often under a different name, different ownership, or even in a different location. The single employer doctrine has no application to that type of situation. In such cases, only the alter ego doctrine offers the possibility of bargaining agreement continuity.

The alter ego doctrine is an effort to pierce changes in corporate form which are undertaken to avoid a union. To decide whether two entities are alter egos of each other, the NLRB looks to see whether the change resulted in a "bona fide discontinuance and a true change of ownership" or was merely a "disguised continuance of the old employer." 156 This inquiry has lead to a list of factors which the NLRB weighs, factors such as whether the two entities have substantially identical management, business purpose, methods of operation, equipment, customers, ownership, supervision, and so forth. ${ }^{167}$ In addition, some courts have held that to find an alter ego, there must be a specific finding that the employer acted with the intent of evading the union and/or its obligations under the NLRA. ${ }^{168}$

Recently at least one circuit has rejected the notion that antiunion intent is required for finding alter ego status, and instead has imposed alter ego status in cases where there was no specific intent by the employer to evade the union. In N.L.R.B. v. Allcoast Transfer, Inc. ${ }^{168}$ where a new company was formed as a split off from another, the NLRB found that the two companies had substantially identical management and supervision, business purpose, equipment and employees, and thus were alter egos of each other. ${ }^{160}$ The Sixth Circuit enforced the NLRB order, rejecting the employer's claim that a finding of anti-union intent is necessary to a finding of alter ego status. The court reviewed the case law on the question and said, "[W]e conclude that a finding of employer intent is not essential or prerequisite to imposition of alter ego status. Instead, it is merely one of the relevant factors which the

${ }^{156}$ Southport Co. v. N.L.R.B., 315 U.S. 100, 106 (1942).

${ }_{187}$ Crawford Door Sales Co., 226 N.L.R.B. 1144, 1144 (1976).

${ }^{158}$ Penntech Papers, Inc. v. N.L.R.B., 706 F.2d 18, 24 (1st Cir. 1983); Iowa Express Distribution, Inc. v. N.L.R.B., 739 F.2d 1305, 1311 (8th Cir. 1984). See also N.L.R.B. v. Scott Printing Corp., 612 F.2d 783 (3rd Cir. 1979). See generally, Note, 54 N.Y.U.L.Rev. at 639 (cited in note 155) (anti-union animus essential element for alter ego finding).

159780 F.2d 576 (6th Cir. 1986).

${ }^{180}$ Id. at 582. 
NLRB can consider." ${ }^{161}$ In setting out the reasons for its position, the court said:

If we were to require a finding of employer intent, an employer who desired to avoid union obligations might be tempted to circumvent the doctrine by altering the corporation's structure based on some legitimate business reason, retaining essentially the same business, and utilizing the change to escape the unwanted obligations. Our flexible approach will discourage such attempts at circumvention . . . . Accordingly, even when legitimate reasons support an alteration in structure, the Board can prevent an employer from avoiding obligations under the Act. ${ }^{162}$

To the extent that other circuits follow the Sixth Circuit, the alter ego doctrine may provide a means to protect unions facing corporate transformations in cases where the employer's intent was not to evade the union per se, but to evade the economic consequences that unions entail. Indeed the alter ego doctrine might become labor's main protection in situations where the labor law doctrines previously discussed provide no remedy-where, for example, a corporation undergoes a merger or reorganization for the purpose of reducing its overall costs, most particularly but not exclusively its labor costs. However, it remains to be seen how many circuits will follow the Sixth Circuit approach, or how the Sixth Circuit will apply its approach in future cases.

\section{Securing Participation Rights by Contract}

The preceding sections have addressed the question of how much input into corporate decision making unions are granted under current interpretations of the NLRA. There remains the question of whether, and to what extent, the law permits unions to obtain participation rights by contract. If unions are entirely free to negotiate for contractual provisions that give them participation rights, and if those provisions are enforceable, then it cannot be said that the NLRA deprives workers of the right to participate, notwithstanding the doctrinal developments discussed above. To

161 Id. at 581.

${ }^{162}$ Allcoast, 780 F.2d at 582. See also Rogers Cleaning Contractors, Inc., 277 N.L.R.B. No. 53 (1985) (finding two employers to be alter egos without making any finding regarding anti-union intent). But see Crest Tankers, Inc. v. Nat'l Maritime Union of America, 796 F.2d 234, 237-238 and n.2 (8th Cir. 1986) (reaffirming intent requirement for alter ego finding). 
the contrary, it could be maintained that the law promotes participation by facilitating collective bargaining, the process from which such participation rights emerge. ${ }^{163}$ Thus, it is important to determine whether, and to what extent, the law permits unions to protect themselves against corporate transformation, or to achieve participation in corporate decision making, by contract.

The current labor laws limit the ability of unions to achieve participation by contract in two ways. First, the NLRA limits the issues about which a union may lawfully negotiate. ${ }^{164}$ The law explicitly prohibits bargaining for certain contractual provisions that would provide protection against corporate transformations, and other potential subjects of bargaining have been prohibited by statutory interpretation. ${ }^{165}$ Second, for those contractual provisions that are lawful, the Norris-LaGuardia Act, ${ }^{168}$ in conjunction with the National Labor Relations Act, has been interpreted so as to prevent unions from enforcing such provisions effectively.

1. Substantive Limitations on Unions' Ability to Contract. The most important limitation on the ability of unions to protect themselves by contract from adverse corporate decisions is found in $\S 8(\mathrm{e})$ of the NLRA. ${ }^{107}$ Section 8(e) was added to the NLRA in 1959 in order to prohibit contractual clauses which, if enforced, induced secondary behavior. ${ }^{168}$ Secondary behavior is prohibited by $\S 8(b)(4)$ of the NLRA, which prohibits unions from engaging in or

${ }^{16 s}$ See, e.g., Blackburn, 18 Hous.L.Rev. at 353 (cited in note 29) (arguing that in the United States, unions achieve participation through collective bargaining).

${ }^{184}$ Labor law draws a distinction between mandatory subjects of bargaining and permissive subjects of bargaining. See note 41 . See also N.L.R.B. v. Borg-Warner Corp., 356 U.S. 342, 349 (1958) (distinguishing mandatory subjects of bargaining from permissive subjects). Mandatory or permissive subjects of bargaining may lawfully be the subject of negotiations and of contractual provisions between unions and employers. Certain other subjects of bargaining are prohibited. Kaiser Steel Corp. v. Mullins, 455 U.S. 72, 77 (1982) (illegal promises in collective bargaining agreement will not be enforced). Examples of such illegal subjects include bargaining for employees not within the bargaining unit, Big E Leasing Corp., 275 N.L.R.B. 1329 (1985); bargaining to expand the scope of the bargaining unit, Sheraton-Kauai Corp. v. N.L.R.B., 429 F.2d 1352, 1356-57 (9th Cir. 1970), Welch Scientific Co. v. N.L.R.B., 340 F.2d 199, 203 (2d Cir. 1966); and bargaining for contractual terms that violate the secondary boycott and antitrust laws, Connell Co. v. Plumbers \& Steamfitters, 421 U.S. 616, 622-23 (1975).

${ }_{165}$ See notes $178-96$ and accompanying text.

16829 U.S.C. $\S \S 101-115$.

167 29 U.S.C. $\$ 158(\mathrm{e})$.

${ }^{168}$ National Woodwork Mfr's Ass'n v. N.L.R.B., 386 U.S. 612,634 (§8(e) intended to plug the hole in the prohibiton against secondary activity which had been identified in earlier case); Theodore J. St. Antoine, Secondary Boycotts and Hot Cargo: A Study in the Balance of Power, 40 U.Det.L.J. 189, 206 and n.78 (1962) (history of $\S 8(e)$ ). 
coercing others to engage in secondary behavior. ${ }^{168}$ Section $8(\mathrm{e})$ works in conjunction with $\S 8(b)(4)$ to constrain secondary activity. Stated simply, §8(e) says that a union and an employer may not enter into a "hot cargo" agreement-an agreement by which the employer agrees to refrain from using or handling products of another employer. ${ }^{170}$ It declares such contractual provisions "unenforcible [sic] and void."171 The statute also provides that union activity which aims to induce an employer to enter into an agreement that violates $\S 8(\mathrm{e})$ is deemed a prohibited secondary boycott under $\S 8(\mathrm{~b})(4)(\mathrm{ii})(\mathrm{A}),{ }^{172}$ and is subject to an injunction at the request of the NLRB ${ }^{173}$ or a damage action brought by an employer or other injured party. ${ }^{174}$ Taken together, these statutory provisions mean that "hot cargo" contractual clauses are not only unenforceable, but also subject a union to injunctions and damage actions merely for negotiating them. Furthermore, in certain cases, a union that engages in such secondary activity loses its exemption from the antitrust acts, and thus is subject to treble damage actions. ${ }^{178}$

Despite the powerful mechanisms for enforcing $§ 8(e)$, the substantive content of the provision is open-textured and vague. Both $\S 8(\mathrm{e})$ and its twin, $\S 8(\mathrm{~b})(4)$, depend on a distinction between primary and secondary union activity to define the contours of lawful and unlawful contractual language. ${ }^{176}$ However, the distinction be-

168 Section $8(b)(4)$ has been described as "one of the most labyrinthine provisions ever included in a federal labor statute." Benjamin Aaron, The Labor-Management Reporting and Disclosure Act of 1959, 73 Harv.L.Rev. 1086, 1113 (1960). While the Act does not use the word "secondary," the prohibitions of $\$ 8(b)(4)$ have been held to apply only to secondary, as compared to primary, union behavior. See id. at 1116; Howard Lesnick, The Gravaman of the Secondary Boycott, 62 Colum.L.Rev. 1363, 1364 (1962).

${ }^{170}$ Such clauses are known as "hot cargo" clauses because, until they were outlawed, they were primarily used by unions to prevent employers from requiring employees to handle struck goods or otherwise to deal with companies with whom the union had a dispute.

171 Kaiser Steel, 455 U.S. at 86 ("[W]hile only the Board may provide affirmative remedies for unfair labor practices, a court may not enforce a contractual provision which violates Section 8(e)").

${ }^{172} 29$ U.S.C. $\$ 158(\mathrm{~b})(4)$.

17329 U.S.C. $\$ 160(1)$.

174 Labor Managment Relations Act, 29 U.S.C. \$187(b).

${ }^{178}$ Connell Co., 421 U.S. at 635; Larry V. Muko v. Southwestern Pennsylvania, 609 F.2d 1368 (3rd Cir. 1979); United States v. Olympia Provision \& Baking Co., 282 F.Supp. 819 (S.D.N.Y. 1968). See generally Bernard T. King and Jules L. Smith, Labor Relations and Antitrust: Developments after Connell, 3 Ind.Rel.L.J. 605, 618-26 (1979) (reviewing postConnell cases concerning circumstances in which a violation of $\$ 8(e)$ leads to liability under the Sherman Act).

${ }^{176}$ Sheet Metal Workers Int'I Ass'n, Loc. U. No. 223 v. N.L.R.B., 498 F.2d 687, 691-92 (D.C.Cir. 1974) (\$8(e) only prohibits secondary behavior). See generally, Howard Lesnick, Job Security and Secondary Boycotts: The Reach of N.L.R.A. §§ 8(b)(4) and 8(e), 113 
tween lawful primary and unlawful secondary union activity has always been evasive at best. ${ }^{177}$ Neither the language of $\S 8(e)$ nor that of $\S 8(b)(4)$ gives much guidance as to precisely what is prohibited. ${ }^{178}$ This lack of clarity has left much room for judicial interpretation.

In recent years, many of the contractual provisions that might provide unions protection against corporate transformations have been held by the NLRB and courts to be illegal hot cargo provisions under $\S \S 8(\mathrm{e})$ and $8(\mathrm{~b})(4)$ (ii). For example, some unions have negotiated provisions that require the employer to subcontract only with union subcontractors, or that require that subcontracters be subject to the same labor agreement as the union negotiating the clause. Unions want these clauses because they eliminate any possible wage or labor cost differential that might be obtained by subcontracting, and thus reduce an employer's incentive to subcontract work out of the bargaining unit. However, such clauses have generally been found to be unlawful under $§ 8(e) .{ }^{179}$ Similarly, unions have attempted to negotiate clauses that say that if an employer sells its assets during the term of the collective bargaining agreement, it must obtain the transferee's assent to be bound by the existing agreement. Such a clause tries to obtain by contract what successorship doctrine, at least after Burns, denies to unions. These provisions, like union-only or contract-only subcontracting clauses, have sometimes been held to be unlawful. ${ }^{180}$

Union efforts to negotiate contractual provisions to protect their members' jobs in the face of automation have also not fared well under $\S \S 8(b)(4)$ and $8(e)$. The courts and the NLRB make a

U.Pa.L.Rev. 1000, 1009-1115 (1965) (history of $\$ 8(e)$ shows that it pertains only to secondary contractual clauses).

177 Electrical Workers v. N.L.R.B., 366 U.S. 667, 672-74 (1961) (distinction between primary and secondary is "more nice than obvious").

${ }^{178}$ See N.L.R.B. v. Int'l Longshoremen's Ass'n ("ILA II"), 473 U.S. 61, 81 (1985) (acknowledging that no clear line separates primary from secondary activity).

179 See, e.g., Unis v. Int'l Bro'hd of Teamsters, 541 F.Supp. 706 (W.D.Pa. 1982) (unionsignatory subcontracting clause violates $\S 8(e)$ ); N.L.R.B. v. Milk Wagon Drivers Union, Local 753, 335 F.2d 326, 328-29 (7th Cir. 1964) (union-only subcontracting clause violates $\S 8(e)$ ). See generally Lesnick, 113 U.Pa.L.Rev. at 1032 (cited in note 176) (NLRB treats union-only subcontracting clauses as secondary).

In contrast, clauses which require an employer to apply union standards to all of its subcontractees, known as "union standards clauses," are sometimes upheld as valid. See, e.g., Lewis v. N.L.R.B., 350 F.2d 801 (D.C.Cir. 1965) (district court remands after NLRB found union standards clause invalid); Meat and Highway Drivers, Dockmen v. N.L.R.B., 335 F.2d 709, 715-717 (D.C.Cir. 1964) (union standards clauses valid).

${ }^{180}$ See, e.g., Danielson v. Int'l Organization of Masters, Mates \& Pilots, 521 F.2d 747 (2d Cir. 1975); N.L.R.B. v. Nat'l Maritime Union of America, 486 F.2d 907 (2d Cir. 1973). 
distinction between union efforts to preserve traditional bargaining unit work, which they consider lawful, and union efforts to acquire new work, which they consider unlawful secondary activity. ${ }^{181} \mathrm{Be}-$ cause automation usually involves some change in the actual work to be performed, many union efforts to hold on to their bargaining units in the face of automation have been prohibited. ${ }^{\mathbf{1 8 2}}$ For example, courts have held that where unions respond to automation by seeking contractual language that would give them the new work which has displaced their traditional work, they have engaged in unlawful secondary activity. ${ }^{183}$ Similarly, efforts by unions to recapture work that had once belonged to their bargaining unit but was lost by a combination of automation and subcontracting has been held to be unlawful. ${ }^{184}$

Recently, the Supreme Court reaffirmed the work preservation-work acquisition distinction but introduced some flexibility into the doctrine. In the N.L.R.B. v. I.L.A. cases, ${ }^{185}$ it said that, to be lawful, a union-negotiated clause need not seek to preserve the identical type of work that its members had performed. Rather, the test was "whether the historical and functional relationship" between work sought to be retained and work previously performed "can support the conclusion that the objective of the agreement was work preservation rather than the satisfaction of union goals elsewhere [i.e., work acquisition]."188 This expanded interpretation of the work preservation doctrine gives unions more leeway to protect themselves from the detrimental consequences of automation. ${ }^{187}$

181 National Woodworkers Mfr's Ass'n, 386 U.S. at 635; N.L.R.B. v. Longshoremen's, 447 U.S. 490, 503-04 (1980) ("I.L.A. I").

${ }^{182}$ See generally, Lesnick, 113 U.Pa.L.Rev. at 1004-05 (cited in note 176); Ted Cassman, Deconsolidating the Work Preservation Doctrine: Dolphin-Associated Transport, 4 Ind.Rel.L.J. 604 (1981).

${ }^{183}$ See Note, Automation and the Work Preservation Doctrine: Accommodating Productivity and Job Security Interests, 32 UCLA L.Rev. 135, 148-49 n. 69 (1984) (work preservation doctrine has thwarted efforts by unions to bargain for assignment of new work to replace jobs lost as a result of automation).

${ }_{184}$ See, e.g., Meat and Highway Drivers Local Union No. 710, 143 N.L.R.B. 1221, modified by 335 F.2d 709 (D.C.Cir. 1964) (union effort to restrict employer's method of deliveries held unlawful). But see N.L.R.B. v. I.L.A. 473 U.S. 61, 77 (1985) ("I.L.A. II") (work preservation agreement that seeks to recapture work eliminated by technological change is not necessarily unlawful). See generally, Note, Work Recapture Agreements and Secondary Boycotts, ILA v. N.L.R.B., 90 Harv.L.Rev. 815, 822-23 (1977) (citing cases adopting narrow approach to union efforts to recapture jobs replacing those lost to automation).

${ }^{185}$ N.L.R.B. v. Int'l Longshoremen's Ass'n, 447 U.S. 490 (1980) (“I.L.A. I"); I.L.A. II, 473 U.S. 61 (1985).

${ }^{188}$ I.L.A. I, 447 U.S. at 510.

${ }^{187}$ See Lesnick, The Supreme Court and Labor Law in the Fiftieth Year of the 
One of the most recent and controversial extensions of the secondary boycott provisions has been to union clauses that seek to limit "double-breasting." Double-breasting is a practice whereby a unionized employer establishes a nonunion entity to perform the same work as its union entity. ${ }^{188}$ Double-breasting began in the construction trades over fifteen years ago and has recently spread to other industries. Unions object to the practice because it allows an employer to siphon off bargaining unit work and transfer that work to a nonunion, and thus lower cost, operation. ${ }^{189}$ Contractors frequently justify the practice by saying that they operate in two different markets-a market that uses only union labor and one that uses nonunion labor-and thus need two different work forces in order to bid successfully on both types of jobs. ${ }^{190}$ Because of this purported business justification, the NLRB had refused to make the practice of double-breasting illegal per se. ${ }^{101}$

Unions have attempted to eliminate the double-breasting practice and thus to retain their bargaining units. ${ }^{192}$ As part of such efforts, unions have developed contractual language that requires employers to perform bargaining unit work by union members. A model contract clause to limit double-breasting was developed by the General Counsels of the Unions affiliated with the AFL-CIO Building Trades Department, and that clause has become standard in the industry. In November, 1985, in a surprise turnabout, the NLRB determined that a union's effort to negotiate for the model anti-double-breasting (or "dual shop") clause was unlawful secondary activity. ${ }^{193}$ In that case, a union was striking to obtain the model dual shop provision. Upon an employer com-

N.L.R.A., 1 Labor Lawyer 703, 715 (1985) (Brennan's opinion in I.L.A. II reaffirmed the primary-secondary dichotomy in the analysis of $\$ 8(\mathrm{e})$, thus narrowing the concept of 'work acquisition').

188 Plumbers Local 669 v. N.L.R.B., 122 L.R.R.M. 2139, 2141 and n.2 (D.C.Cir. 1986). See also South Prairie Construction Co. v. Local 627, Int'l Union of Operating Engineers, 425 U.S. 800 (1976).

189 Plumbers Local 669 v. N.L.R.B., 122 L.R.R.M. at 2144 (affirming NLRB's finding that employer unlawfully diverted work from its union to its nonunion company).

190 Comment, Double-Breasted Operations in the Construction Industry, 6 U.Dayton L.Rev. 45, 45-46 (1981).

191 Carpenters Local Union No. 1478 v. Stevens, 743 F.2d 1271, 1275 (9th Cir. 1984). For a critique of this position, see Bernard T. King and James R. LaVaute, Current Trends In Construction Industry Labor Relations-The Double-Breasted Contractor and the PreHire Contract, 29 Syracuse L.Rev. 901, 902-28 (1978).

${ }^{182}$ See, e.g., Carpenters Local Union No. 1846 v. Pratt-Farnsworth, Inc., 690 F.2d 489, 497 (5th Cir. 1982) (cataloging different ways unions have sought to limit or eliminate double-breasting).

${ }^{193}$ D'Amico v. Painters District Council 51, 120 L.R.R.M. 3473, 3477 (D.Md. 1985). 
plaint, the NLRB determined for the first time that the model clause was a "hot cargo" provision in violation of $\S 8(\mathrm{e})$, and accordingly the NLRB sought an injunction against the strike. The federal district court in Maryland granted the injunction. ${ }^{194}$

In its opinion, the court stressed that the anti-double-breasting contract clause would have imposed contractual terms on the parent company of the immediate employer, and presumably from there upon its other subsidiaries. It said that under the clause,

the fact of common ownership alone of two or more business entities, irrespective of the fact that they may have separate and distinct operations, would require a non-signatory parent company and all its subsidiaries to conform to the terms of a collective bargaining agreement signed only by one of the parent's subsidiaries. ${ }^{195}$

This aspect of the clause was what made it secondary, and therefore unlawful. ${ }^{198}$

The double-breasting decision demonstrates that, as corporate structures become more complex, union efforts to protect their members become more difficult and more perilous. In the face of corporate structures that have identical or overlapping ownership, management, customers, and assets, unions are trying to protect the unionized portions of the work by contracting for uniformity in labor costs. The use of the secondary boycott laws against such efforts reflects both the plasticity of the primary-secondary distinction and the unwillingness of the courts or the NLRB to permit union influence to follow the ever-changing shapes and forms of the corporation.

2. The Problem of Enforcing Contractual Protections. In addition to the substantive limitations on contractual provisions available to unions to protect themselves against corporate transformations, unions also encounter serious obstacles in the contract enforcement process. The most effective means of enforcing contractual provisions that restrict management's ability to partially

104 Id. at $3480-81$.

${ }^{193}$ Id. at 3477 . The court called this feature of the clause "bottom up" as opposed to "top down" double-breasting. Id.

196 In similar double-breasted situations, courts have found that for a union contractually to impose the terms of its collective agreement on a non-union co-subsidiary was improper, and that any such agreement was unenforceable. Carpenters Local Union v. Stevens, 743 F.2d at 1278. But see R.B. Electric v. Teamsters Local 569, 119 L.R.R.M. 2821, 2824-25 (9th Cir. 1985) (interpreting Carpenters decision narrowly to apply only in cases where the NLRB has determined that the two co-subsidiaries are neither alter egos nor a single employer). 
terminate operations, relocate or reorganize is an injunction. Company action often cannot be undone and the workers' losses cannot easily be compensated. Thus, unions faced with breaches of contractual protections frequently seek temporary injunctions, asking courts to preserve the status quo pending a decision by an arbitrator enforcing the contractual provision..$^{197}$

However, unions have had a difficult time obtaining specific enforcement of protective contractual provisions for two reasons. First, in accordance with the usual rules of equity jurisdiction, unions requesting injunctions must show that they are threatened with irreparable harm. While it may seem intuitive that workers faced with certain and permament job loss face irreparable harm, the courts generally do not agree. Instead, many courts hold that job loss alone cannot constitute irreparable harm because the losses can be compensated later. ${ }^{198}$ This formulation ignores the less tangible losses at stake, such as loss of medical benefits, accumulated seniority, investments in human capital, and the intangible psychological benefits of job security. Yet in many circuits, unions cannot prevail on the issue that job loss, even massive job loss, is irreparable harm. ${ }^{199}$ Thus, to obtain injunctive relief, they must find some other way of satisfying this requirement. ${ }^{200}$

The second legal impediment to judicial enforcement of protective contractual provisions is, ironically, the Norris-LaGuardia

${ }^{197}$ Such injunctions are called "Reverse Boys Market" injunctions, referring to Boys Market v. Retail Clerks, 398 U.S. 235 (1970), in which the Court held that an employer could obtain an injunction to restrain its workers from striking over a dispute which was subject to the arbitration clause in a collective agreement. Reverse Boys Market injunctions arise when unions seek to restrain employer action in violation of collective bargaining agreements pending arbitration of the dispute. See, e.g., Lever Bros. v. Int'l Chem. Workers Local 217, 554 F.2d 115, 122-23 (4th Cir. 1976). See generally, Stone, Post-War Paradigm, 90 Yale L.J. at 1542-43 \& n. 185 (cited in note 33); William B. Gould, On Labor Injunctions Pending Arbitration: Recasting Buffalo Forge, 30 Stan.L.Rev. 533, 552-61 (1978).

188 See, e.g., Aluminum Workers Intern. v. Consol. Aluminum Corp., 696 F.2d 437, 443 (6th Cir. 1982); Amalgamated Local 813, Intern. U. v. Diebold, Inc., 605 F. Supp. 32, 36-37 (N.D. Ohio 1984); Loc. 274, Hotel Emp. v. Westin Bellevue Stratford, 633 F. Supp. 869, 870 (E.D.Pa. 1986) (no irreparable harm for job losses). But see Lever Bros., 554 F.2d at 123 (finding irreparable harm in a relocation decision that threatens to render subsequent arbitration a "hollow formality"); Drivers, Chauffers, Etc. v. Akers Motor Lines, 582 F.2d 1336, 1341 (4th Cir. 1978) (irreparable harm when employer liquidated assets of entire business).

${ }^{199}$ Similarily, some courts have stated that a union's inability to enforce its contractual provisions, and its concommitant lack of prestige, do not constitute irreparable harm. Intern U., United Auto, Etc. v. LaSalle Mach. Tool, Inc., 696 F.2d 452, 458 (6th Cir. 1982).

${ }^{200}$ See, e.g., Local 553, Transport Workers v. Eastern Air Lines, 695 F.2d 668, 677-78 (2d Cir. 1982) (finding irreparable harm and granting injunction because of impossibility of identifying which employees would be injured by company's action). 
Act, ${ }^{201}$ an Act passed in 1933 to protect unions against injunctions sought by employers. The Act prohibits certain injunctions in labor disputes, particularly injunctions against strikes. ${ }^{202}$ For other types of injunctions in labor disputes, the Norris-LaGuardia Act sets out stiff procedural requirements designed to ensure procedural regularity and to place a high burden of persuasion on the party seeking the injunction. ${ }^{203}$ In addition, $\S \S 7$ and 9 of the Act call for a full evidentiary hearing and detailed findings of fact by the court before even a temporary injunction can issue. ${ }^{204}$ As a result of these procedural requirements, courts have frequently refused to grant injunctions requested by unions to enforce protective contractual provisions because the union could not make the requisite showing. ${ }^{205}$

These two impediments mean that it is difficult for unions to enforce contractual protections by injunctive relief. Moreover, in most cases a union cannot sue for damages, because the labor laws have been interpreted to require a union complaining of a breach of collective agreement to bring its claim to an arbitral forum. ${ }^{206}$ In general, arbitrators have been reluctant to grant the kinds of drastic relief that the situations require.

\section{E. Summary}

The power broker aspects of the labor laws have been re-interpreted in a way that narrows the abilities of unions to achieve participation through conventional collective bargaining. At other times in the NLRA's history, however, other doctrines have offered unions broader possibilities for participation. Those doctrines that have narrowed the possibilities for participation could be altered to permit participation by simply restoring, or even expanding, some

20129 U.S.C. § 101 et. seq.

20229 U.S.C. $\$ 104(\mathrm{a})$.

${ }^{205}$ See, e.g., 29 U.S.C. $\$ \S 107$ (b) and (c) (party seeking injunction must show substantial and irreparable harm, and balance of hardships in its favor as to each of item of relief requested).

${ }^{204} 29$ U.S.C. $\$ \S 107$ and 109.

${ }^{205}$ See, e.g., LaSalle Mach. Tool, 696 F.2d 452 (\$§ 7 and 9 of Norris-LaGuardia Act prevent union from obtaining injunction to enforce no-subcontracting agreement); United Telegraph Workers, AFL-CIO v. Western Union, 771 F.2d 699 (3rd Cir. 1985) (union cannot obtain injunction to enforce contractual provision giving it access to information and participation rights because of failure to satisfy $\S 7$ and 9 of Norris-LaGuardia Act). But see, Local Lodge No. 1266, Int'l Ass'n of Machinists v. Panoramic Corp., 668 F.2d 276, 29091 (7th Cir. 1981) (suggesting full compliance with $\$ 7$ of Norris-LaGuardia Act not necessary for a reverse Boys Market injunction).

${ }^{208}$ Stone, Post-War Paradigm at 1529-30 (cited in note 33). 
of the earlier doctrines. None of these changes would undermine the regulatory scheme of the NLRA-indeed, most of these doctrines have undergone such changes at different times during the history of the NLRA.

The more difficult question is whether the constitutive aspects of labor law prohibit participation in such a way as to make the regulatory scheme incompatible with increased participation. I address this question in Part III.

\section{BarRiers to Participation in the Constitutive Features of THE NLRA}

While the preceding history of the interpretation of various provisions of the National Labor Relations Act demonstrates that there are no necessary conflicts or incompatibilities between the Act's power broker features and increased union participation in management, the same cannot be said of its constitutive features. To the contrary, one finds a persistent conflict between union participation efforts and the constitutive aspects of the NLRA. The NLRB has taken the position that intrusion by labor into areas traditionally known as management disqualifies a union from representing the employees and deprives the employees involved of the protections of the statute. The NLRB has done this by invoking the provisions of the NLRA that define "employee"20z and "labor organization"208 and that prohibit both employer domination of a "labor organization"208 and union meddling in management. ${ }^{210}$ These are the constitutive aspects of labor law, the aspects which define the union, which designate who can be included in a union, and which protect a union from intrusion by management. These provisions delineate the boundaries between labor and management.

It is not surprising that union participation should implicate the constitutive features of the NLRA because the new developments in participation purport to, and may in fact, "blur distinctions between management and labor."211 What remains to be explored, however, is whether the constitutive features of the NLRA have to be interpreted in a way that precludes union participation.

${ }^{207}$ National Labor Relations Act \$2(3), 29 U.S.C. \$152(3).

208 Id. at $\$ 2(5), 29$ U.S.C. $\$ 152(5)$.

${ }^{209}$ Id. at $\S 8(\mathrm{a})(2), 29$ U.S.C. $\S 158(\mathrm{a})(2)$.

${ }^{210}$ Id. at $\S 8(b)(1)(B), 29$ U.S.C. $\$ 158(b)(1)(B)$.

${ }^{211}$ Hoerr, Business Week at 38 (cited in note 28) (quoting Undersecretary of Labor Steven Schlossburg). 
Must the boundaries between labor and management be defined so as to keep unions out of major decision making? The question of compatibility is the question of whether the boundaries between management and labor must be defined in a particular way. The answer to that question determines whether the basic framework of labor regulation embodied in the labor laws precludes union participation in management.

While the NLRB has regularly used the boundary-defining provisions of the NLRA to inhibit employee participation, its rationales have varied in different contexts. Thus, the asserted boundary between management and labor that operates when employees own stock is somewhat different from the boundary when a union representative sits on a board of directors or when employees have a collective voice in decisions about their work. These rationales must be examined in order to evaluate whether the boundaries are so rigid and inviolable as to prohibit employee participation in corporate decision making under the NLRA. Therefore, I will examine the rules and rationales the NLRB has developed for maintaining the different boundaries that it has set up in these various contexts. After doing so, I will look critically at the assumptions underlying the boundaries and question whether they are the only possible way to implement the NLRA.

A. The Boundary Between Employees and Stockholders: Employee Stock Ownership ${ }^{212}$

The relationship between employee ownership and collective bargaining was first addressed in cases involving producer cooperatives. One of the first cases arose in 1946 when the United Furniture Workers Union attempted to organize the Union Furniture Company. ${ }^{213}$ The Union Furniture Company originally had been incorporated in 1867 as a producer cooperative. Initially, it had 30 to 35 stockholders, all of whom worked in the plant, and each of whom owned one share. The original by-laws provided that the company had the option of purchasing the stock of stockholders who died or chose to sell. Over time, the original stockholders either sold their stock or passed it on to heirs so that as of the time

${ }^{212}$ Good descriptions of employee ownership can be found in Deborah Groban Olsen, Union Experiences with Worker Ownership, 1982 Wisc.L.Rev. 729; Note, ESOPs Tables: A Survey of Companies with Employee Stock Ownership Plans, 6 J.Corp.L. 551 (1981); Corey M. Rosen, Katherine J. Klein, and Karen M. Young, Employee Ownership in America (1986).

213 Union Furniture Company, 67 N.L.R.B. 1307 (1946). 
of the organizing drive, there were 26 stockholders in all.

The United Furniture Workers sought to organize a bargaining unit composed of approximately ninety production employees. ${ }^{214}$ The union sought to exclude another nine production employees from the unit on the grounds that they were stockholders. ${ }^{215}$ Four of the nine also were on the board of directors. The company wanted the employee-stockholders and employee-directors included in the unit, presumably because it believed that they would vote against the union.

The NLRB was thus called upon to decide who was in the unit and then to schedule an election. ${ }^{216}$ In a landmark decision, the NLRB decided to exclude the employee-stockholders from the unit. It reached this conclusion because the employee-stockholders held a substantial minority of the voting stock. The NLRB pointed out that the employee-stockholders had "a strong voice in the election of directors . . . . Furthermore, matters of fundamental labor policy, such as granting or refusing a closed shop, would be referred to the stockholders."

The NLRB concluded that the employee-stockholders had too much power to be considered employees eligible for inclusion in the bargaining unit. It elaborated:

It is true that the mere ownership of stock in a corporation does not preclude the inclusion of a stockholder in a collective bargaining unit of the corporation's employees. Yet, patently, a distinction must be drawn between the fact pattern here present and a situation where stock ownership is so dispersed or disparate as to afford a given stockholder a negligible interest in determining corporate policy. ${ }^{218}$

The problem, then, was that employee-stockholders had too much power as stockholders. ${ }^{210}$

The NLRB also gave another reason for excluding the employee-stockowners. Because only nine of the ninety-odd produc-

214 Id. at 1308 n.1.

215 Id. at 1310.

${ }^{216}$ See N.L.R.A. $\S \S 9(b)$ and (c), 29 U.S.C. $\$ 159$ (b) and (c).

${ }_{217}$ Union Furniture, 67 N.L.R.B. at 1310.

218 Id. at 1309-10.

${ }^{218}$ This case changed previous NLRB policy. Earlier, in Olympia Shingle Company, 26 N.L.R.B. 1398 (1940), the NLRB said that employees in a producer cooperative, where all employees owned equal shares of stock, were employees within the meaning of the statute. It reasoned that, notwithstanding that a majority of employees thus had control of company policy, their interests as stockholders did not "outweigh or overshadow their interests as workers." Id. at 1414. 
tion employees owned any stock at all, the NLRB found that the employee-owners and employee-nonowners could not be in a bargaining unit together. It said that " $[t]$ he interest of the stockholder employees is generally recognized by the rank and file workers who number approximately 90 , and cannot fail to have considerable impact on their behavior." 220 In other words, the NLRB felt that the non-stockholder employees would perceive that they had interests that diverged from, and perhaps conflicted with, those of the employee-stockholders. It was the conjunction of these two factors-the divergence of interests between stockholding employees and non-stockholding employees and the degree of employeestockholder influence on management-that the NLRB used to justify its exclusion of stockholding employees from the bargaining unit.

The two factors that were dispositive in Union Furniture Co. have continued to dominate the NLRB's analysis of employee ownership issues. For example, in the 1952 Brookings Plywood Corporation case, involving another producer cooperative, the NLRB excluded employee-stockholders from a bargaining unit where, of 242 stockholders, 118 were employees. ${ }^{221}$ It justified the exclusion, saying, "[t]hat such a large and homogeneous group of stockholders may influence management policies is not a remote possibility in this case."222 Furthermore, the NLRB noted that the stockholder employees seemed to receive preferential treatment ${ }^{223}$ and from this surmised that the non-stockholder employees had different employment interests than the stockholder employees.

Though to date there has been no distribution of profits, we recognize that stockholders, who are interested in maximizing profits, would favor minimizing costs, including that of the nonstockholder labor, whereas the representative of the latter would constantly seek to obtain higher wages for its members. ${ }^{224}$

The older employee ownership cases thus focused on two fac-

220 United Furniture, 67 N.L.R.B. at 1310.

22198 N.L.R.B. 794, 798 (1952).

${ }^{222}$ Id. (emphasis added). Compare this with Alderwood Products Corporation, 81 N.L.R.B. 136, 138 (1949), where the NLRB did not exclude stockholder employees from the bargaining unit of a sawmill company because there was no "conclusive evidence that the employee-stockholders herein concerned exercise as stockholders an effective control over corporate policy."

${ }^{223} 98$ N.L.R.B. at 799. The most desirable jobs were in the plywood plant itself, and there 113 of the 117 employees owned stock. Id. at 798 n.15.

224 Id. at 799. 
tors: the potential for the exercise of power by employee-owners and the posited divergent interests of employee-owners and employee-nonowners. ${ }^{225}$ The first factor constructs a hard boundary between labor and management by saying that whenever employees become a powerful factor in a company's ownership, the employees are no longer "employees" in the statutory sense. They then lose all of the NLRA's protection. ${ }^{226}$

More recently, the NLRB has shifted in its treatment of employee ownership issues. It has continued to apply the same two factors, but it has done so in a way that softens the boundaries between labor and management. It no longer disqualifies employee-owners from collective bargaining where they have the potential to exercise power, but only where they actually exercise power or when the possibility for its exercise is quite real. In $S-B$ Printers, Inc., for example, the NLRB permitted employees to unionize despite widespread employee stock ownership. It reasoned that, while employees owned 25 percent of the stock, there was no showing that the stockholder employees would vote their stock as a bloc. ${ }^{227}$ Absent a showing of actual exercise of power or of a real possibility of its exercise the NLRB would not disqualify the employees.

In the same case, the NLRB also softened its approach to divergent interests by looking only for an actual, not potential, divergence of interests between employee-owners and nonowners. Thus, it focused only on preferential treatment for employee-owners, ignoring the types of subtle and subjective divergences that the NLRB had discussed in Union Furniture and Brookings Plywood. In $S-B$ Printing it found merely that there was no preferential treatment of employee-stockholders, and on that basis held that the interests of stockholder-employees and non-stockholder-em-

225 See also Mutual Rough Hat Company, 86 N.L.R.B. 440, 444 (1949) (stockholder employees included in bargaining unit because, of fifteen stockholders, only three were employees and because stockholder employees did not receive preferential treatment); Coastal Plywood \& Timber Company, 102 N.L.R.B. 300 (1953) (stockholder employees included in bargaining unit because, of 250 stockholders, only 50 were employees, and because the stockholder employees had the same working conditions and wage scale as the non-stockholder employees).

${ }^{228}$ Compare Red and White Airway Cab Company, 123 N.L.R.B. 83, 85 (1959) (excluding stockholder employees when their stockholding interest gives them "effective voice" in corporate policy) with Blue and White Cab Co., 126 N.L.R.B. 956, 960 (1960) (where stockholder employees own approximately 6 out of a total of 96 shares, they can be included in a bargaining unit because they do not have an effective voice in the management of the company).

22727 N.L.R.B. 1274, 1275 (1977). 
ployees did not diverge. ${ }^{228}$

Despite the softening of the boundaries in the more recent cases, the NLRB's two-factor approach presents significant obstacles to union or employee efforts to obtain power in corporate decision making through the mechanism of employee-ownership. The first factor means that as soon as employees acquire a real possibility of exercising power in management, they lose the protection of the NLRA. This doctrine appears to prevent unions from exercising power through stock ownership. Even the recent reformulations have this effect because the NLRB's soft boundary position still disqualifies employees from unionizing under the NLRA when, as stockowners, they form a homogeneous group or are likely to vote their stock as a bloc. Bloc voting, however, is precisely the mechanism that offers employees real power in management. In particular, employee ownership through an employee stock ownership plan, where stock is held in a voting trust, or through direct union ownership, is the most promising way for unions to use stock ownership to influence management policy. Such an arrangement permits employees to aggregate their stock power and to focus their efforts on union-specific concerns. Yet it is just such arrangements that even the soft boundary approach would prohibit.

Furthermore, there is evidence that the NLRB is willing to rely on the existence of ownership power alone to disqualify employee-owners from collective bargaining. In a 1982 case, Florence Volunteer Fire Department, Inc., ${ }^{229}$ the NLRB refused to permit firefighters to unionize. While the Department was a non-profit corporation, the NLRB's treatment of the case parallels its treatment of employee stockholders in conventional corporations. One of the grounds for its holding was that all firemen were members of the Department, where membership, like share ownership, conferred the right to vote on all aspects of the employer's operations. ${ }^{230}$ Here, there was no division between shareholder and nonshareholder employees, no concern about preferential treatment, nor divergence of members' and non-members' interests. Rather,

${ }^{228}$ Id. The soft boundary approach does not automatically mean that employee-owners can engage in collective bargaining. For example, in Sida of Hawaii, Inc., 191 N.L.R.B. 194 (1971), stockholder employees in a taxicab company were excluded from a bargaining unit because of 142 stockholders, 115 were employees, and because those 115 enjoyed preferential treatment over employees. Id. at 195.

229265 N.L.R.B. 955 (1982).

${ }^{230}$ Id. at 956. The other ground was that two firefighters sat on the fire department's executive committee. The treatment of this issue seems to follow the treatment of employee representatives on boards of directors of for-profit corporations. See Part III.B. 
all firefighters stood on equal footing as members. They were disqualified simply because, as members, the firefighters had too much power. ${ }^{231}$

The NLRB's position on employee ownership, particularly its apparent willingness to rely on the first factor alone, raises a question: why should the potential, or actual, exercise of decision making power through stock ownership disqualify a group of employees from collective bargaining? The answer is not obvious. It cannot be that collective bargaining is antithetical to the exercise of power by employees. Indeed, the promise of collective bargaining is quite the opposite-it promises to be a means for attainment of power. Therefore, the doctrine that says that employee owners cannot join unions if they are powerful in their capacity as owners must be based on the concept that "stock power" is different from "union power," and that it is the wrong kind of power from the point of view of the labor laws. I will explore this dichotomy, and its limitations, in Part IV.

\section{B. The Boundary Between Employees and Directors: Union Representation on Boards of Directors ${ }^{232}$}

The NLRB has taken an approach to union representation on boards of directors that parallels its approach to employee ownership. Again, Union Furniture is the place to start. There, in addition to the nine employee-stockholders, four of the seven members of the company's board of directors were non-supervisory, production employees. The NLRB examined the company's by-laws and practices to see what powers the board of directors exercised. It concluded that the board of directors had the power to elect and fire the company's officers and that it decided "important matters of labor policy." On that basis, the NLRB excluded the directoremployees from the unit, as their interests were held to be "incompatible with those of the rank and file employees." ${ }^{233}$ No further explanation was given.

231 There was another category of members present in the case, the volunteer, unpaid, firefighters. However, there was no question of including the unpaid firefighters in the bargaining unit, and there was no consideration of possible prejudice to them should the paid firefighters be permitted to unionize. Thus their status was irrelevant to the NLRB's decision.

${ }^{232}$ For general description of union representation on corporate boards, see Blumburg, in Westin and Salisbury, Individual Rights in the Corporation at 335 (cited in note 20); James Furlong, Labor in the Boardroom 108-33 (1977); Moberly, 15 Stetson L.Rev. at 99104 (cited in note 22).

${ }^{23 s} 67$ N.L.R.B. at $1309-10$. 
From 1946 until about 1960, the NLRB automatically excluded employees who were on their company's board of directors from bargaining units on the ground that they were part of management. Thus, for example, in Everett Plywood \& Door Corporation, a case involving a plywood cooperative, the NLRB held the stockholder employees could be in a bargaining unit, but that those stockholder employees who are elected to the board of directors must be excluded "because they are a clear management group."234 Similarly, in Blue \& White Cab Co., a taxicab cooperative, the NLRB permitted employee-owners to be in the union, but excluded the one owner-driver on the board because "he is in a position to formulate and determine corporate policy."235

By calling employee-directors "managerial," the NLRB was evoking its doctrine that managerial employees are not eligible for collective bargaining. ${ }^{238}$ In that period, the NLRB applied a broad exclusion to all managerial employees, which it defined as employees who "formulate and effectuate management policies." cluded director-employees in that category and automatically excluded them. However, beginning in the late 1960s and continuing into the early $1970 \mathrm{~s}$, the NLRB narrowed the managerial exclusion, applying it only to members of management who directly helped set or implement labor relations policy. ${ }^{238}$ Under this narrowed managerial exclusion, employee-directors were no longer automatically excluded. However, at the same time, the NLRB widened its pre-existing conflict of interest doctrine to keep employeedirectors out of bargaining units.

The NLRB had previously had a conflict of interest doctrine which disqualified unions from representing groups of workers where there was a "proximate danger that the union would not consider the sole interest of the employees rather than some ulte-

234105 N.L.R.B. 17,20 and n.4 (1953).

${ }^{295} 126$ N.L.R.B. at 957. See also Alderwood Products Corporation, 81 N.L.R.B. 136, 138 and n.5 (1949) ("Stockholders who are members of the board of directors, hold executive or supervisory positions, or fall within any of the other excluded categories, are . . . excluded from the said voting group"); The Dallas Times Herald, 126 N.L.R.B. 600, 602 (1960) (excluding from bargaining unit editorial page editor who was on employer's board of directors because "[a]s a member of such board, he is in a position to formulate and determine corporate policy").

${ }^{236}$ The managerial exclusion will be discussed in detail in Part III.C.

$2 s 7$ N.L.R.B. v. Bell Aerospace Co., 416 U.S. 267 (1974).

$2 s 8$ Bell Aerospace Company, 196 N.L.R.B. 827, 828 (1972), rev'd as NLRB v. Bell Aerospace Co., 416 U.S. 267 (1974). For a more detailed history of the managerial exclusion, see id. at 275-89. 
rior motive."239 For example, they disqualified a union which operated a business in competition with an employer whose employees it sought to organize. ${ }^{240}$ In that period, the NLRB had interpreted the conflict of interest doctrine narrowly, leading one court to observe that " $[w]$ here the union does not compete with the employer and has neither a financial stake in the employer's continued wellbeing nor objectives inconsistent with the employee interests, the Board has not found a disqualifying conflict of interest."241

Beginning in the 1970s, the NLRB extended its conflict of interest doctrine to disqualify unions whose officials also served on corporate boards of directors. It did this in a series of cases where union officers served on the boards of health centers which the union had established for its members. As a result of collective bargaining agreements, these institutions often received payments from the employer to cover the employees' health needs. In order to ensure quality service for its membership, the union frequently occupied positions on the health center's board and helped select its day-to-day administrators. A legal problem arose if the union then also attempted to organize and represent the center's work force. In this situation, the NLRB considers whether the union is disqualified because it sits on the board of directors.

In the first such case, Centerville Clinics, Inc., the NLRB disqualified a union seeking to represent a clinic's workforce when almost all of the members of the clinic's board were members of the union. ${ }^{242}$ Subsequently, the NLRB explained its reasoning in Medical Foundation of Bellaire, ${ }^{243}$ a case in which a union occupied 16 out of 34 seats on the clinic's board of trustees. It said:

The principle has been long and well established that employees have the right to be represented in collective bargaining by a union which has the single-minded purpose of protecting and advancing their interests vis-a-vis the employer and there must be no ulterior purpose. Where the union has direct and immediate allegiances which can fairly be said to conflict with its function of protecting and advancing the interests of the employees it represents, it cannot be a proper representative. On its part, the employer is under a duty to refrain from any action which would interfere with the employees' right to have

${ }^{238}$ Nat'l. Labor Rel. Board v. Pinkerton's, 621 F.2d 1322, 1326 (6th Cir. 1980).

${ }^{240}$ See Bausch \& Lomb Optical Company, 108 N.L.R.B. 1555 (1954).

${ }^{241}$ Nat'l Labor Rel. Board v. Pinkerton's, 621 F.2d at 1326-27.

242181 N.L.R.B. 135, 140 (1970).

${ }^{243} 193$ N.L.R.B. 62 (1971). 
such a representative and which would 'place him even in slight degree on both sides of the bargaining table. ${ }^{244}$

Thus, when unions seek representation on boards of directors, the NLRB now frames its objection in terms of conflict of interest. Its discussions emphasize the danger to employees of having the same people sit on both sides of the bargaining table. Again, the NLRB wants to maintain a boundary, in this case quite a literal boundary, dividing the two sides of the table.

However, as with employee ownership, the NLRB has recently relaxed its test for disqualifying a union that sits on the employer's board by moving from a potential conflict to an actual conflict test. ${ }^{245}$ For example, in Anchorage Community Hospital, ${ }^{246}$ the NLRB refused to find a $\S 8(a)(2)$ violation or disqualify a union even though it held seven out of fifteen seats on the hospital's board. It said that there was neither sufficient board control nor sufficient financial support to disqualify the union from representing the center's employees. ${ }^{24}$ More recently, in Child Day Care Center, the NLRB articulated its new approach to union directorships:

The Board has held that a union's participation in a trust fund does not preclude its representation of the Fund's employees where union officials do not represent a majority on the board of trustees and there is no other reason to suppose that the union is unable to approach negotiations with the single-minded purpose of protecting and advocating the interests of employees. ${ }^{248}$

The conflict of interest test has thus moved away from a blanket prohibition on unions serving on company boards. Rather it

244 Id. at 64 (footnotes omitted), citing Nassau and Suffolk Contractors' Association, Inc., 118 N.L.R.B. 174, 187 (1957). The NLRB went on to say that:

To establish such a disabling conflict of interests . . . the union or the employer need not have effective domination or control of the other, but [there merely must] exist the potential of a conflict or a 'proximate danger of infection of the bargaining process.'

193 N.L.R.B. at 64, citing N.L.R.B. v. David Buttrick Company, 399 F.2d 505, 508 (1st Cir. 1968).

${ }^{245}$ See St. Louis Labor Health Institute, 230 N.L.R.B. 180, 182 (1977) (acknowledging only that NLRB's attitude may be shifting from a potential conflict to an actual conflict test).

248225 N.L.R.B. 575 (1976).

${ }^{247}$ Id. at 575. The union was only responsible for between five and ten percent of the center's revenues. But see id. at 576-77 (Member Walther dissenting) (arguing that union should be disqualified when there is potential for conflict of interest, even if actual conflict has not arisen).

${ }^{248} 252$ N.L.R.B. 1177, 1177 (1980) (emphasis added). 
remains a blanket prohibition where a union controls a majority of an employer's board, but where the union controls something less than a majority, the NLRB looks for some "other reason" to find that a conflict of interest exists. Thus it undertakes a case-by-case inquiry into the possible conflicts posed by the actual individuals involved.

Recent cases illustrate how the case-by-case inquiry operates. In Child Day Care Center itself, for example, the administrators of a union-sponsored health fund encouraged the fund's employees to unionize. A complaint was filed alleging that the union could not represent the employees due to a conflict of interest and that because of this conflict, the fund, by recognizing and bargaining with the union, committed a $\S 8(a)(2)$ violation. The Administrative Law Judge found a conflict of interest because the union appointed one-half of the board and a union-appointed trustee served as its chairman. The NLRB rejected this reasoning, and based its finding of a conflict on the sole ground that one of the union-appointed trustees on the board was the union local's business agent. ${ }^{249}$

The NLRB's shift from a potential conflict to an actual conflict test to judge the legality of union participation on company boards and its refusal to impose a per se illegality except where the union members constitute a majority of the board represents a liberalization of the earlier doctrine. Nevertheless, if a union achieves a majority on the board, it still loses its status as a union. Stated differently, the liberalization in the NLRB's treatment of union directorships retains the conception of labor and management that requires a boundary in the first place. The NLRB's shift alters the quantum of proof necessary to establish a violation, but the boundary itself remains.

The precise nature of the alleged conflict of interest that leads to disqualification is a little obscure. It is not altogether clear why there is a conflict of interest when union representatives sit on a company board, either as a minority or as a majority voice on a board. ${ }^{280}$ The phrase that the NLRB uses most frequently to

249 Id. Similarly, in St. Louis Labor Health Institute, 230 N.L.R.B. 180, the NLRB disqualified a union from representing employees of a health center that it had established to render medical services for the union's members. Again, the NLRB ignored the fact that the principal officers of the Institute were union officials, id. at 183 , and found violations only because the union president served as the principal negotiator for the Institute in the collective bargaining negotiations. On the basis of this fact alone, the NLRB found that the "same people sit on both sides of the bargaining table." Id. at 182.

${ }^{250}$ Several commentators have attempted to reconcile unionism with labor representation on boards by urging that union board members limit their participation to issues which 
dramatize this doctrine is that a conflict exists when the same persons, or entities, sit on "both sides of the bargaining table."261 When the person sitting on both sides is literally the same human being, as it was in the Child Day Care Center case, it is easy to visualize why there might be a problem, at least for the laws of physics, if not for the laws of collective bargaining. However, when the two sides of the table are occupied by different individuals, the justification for finding a disqualifying conflict is less obvious.

I examine the nature of this alleged conflict, and the conclusion that it compels union disqualification, in Part IV. Before doing so, however, there is one more doctrine that bears discussion-the managerial exclusion. It shares a number of themes with the NLRB's treatment of employee stock ownership and union representation on corporate directorates, and it therefore completes the picture of the NLRB's boundary line between labor and management.

\section{The Boundary Between Employees and Management: Collective Employee Decision Making and Control}

The NLRB and the courts have drawn a sharp line between employees on the one hand and decision making groups in the enterprise on the other by means of the supervisory and managerial exclusions. These exclusions separate statutory employees from other employees higher up the hierarchical ladder, thereby establishing a boundary between employees and management.

The question of distinguishing statutory "employees" from supervisors first arose in the 1930s and 40s in cases in which foremen sought to organize into unions. The NLRB went through several about-faces on the question, but by the mid-1940s, its policy was to certify foremen's unions. ${ }^{252}$ In 1947 , one such case came to the

do not have an impact on the union's membership. See, generally, Blackburn, 18 Hous.L.Rev. at 365-66 (cited in note 29) (collecting citations and criticizing possibility of so segregating board issues). This suggestion concedes the issue of unions actually exercising power through board membership. See Part IV, below.

${ }^{251}$ See Centerville Clinics, Inc., 181 N.L.R.B. 135, 140 (1970); St. Louis Labor Health Institute, 230 N.L.R.B. at 182.

${ }^{252}$ See, e.g., Packard Motor Car Company, 64 N.L.R.B. 1212 (1945) (supervisory employees entitled to self-organization under the NLRA). But see, e.g., Mueller Brass Company, 39 N.L.R.B. 167 (1942) (excluding supervisors from rank-and-file bargaining units); Godchaux Sugars, Inc., 44 N.L.R.B. 874 (1942) (approving a unit of supervisors affliated with union of rank-and-file employees); The Maryland Drydock Company, 49 N.L.R.B. 733 (1943) (no unit appropriate for supervisory employees). See also Bell Aerospace Co., 416 U.S. at 274-90 (discussing NLRB's policy reversals in that period). 
Supreme Court. The issue in Packard Co. v. Labor Board ${ }^{253}$ was whether foremen were "employees" under the NLRA and thus entitled to engage in collective bargaining. Writing for the majority, Justice Jackson held that they were. He said that even though foremen have some supervisory responsibilities, they "still have interests of their own as employees." Thus, foremen can be faithful representatives of the employer in maintaining production schedules, while still pursuing their own separate and adverse interests "when it comes to fixing [their] own wages, hours, seniority rights, or working conditions." 254

Justice Douglas, in dissent, took a different view. He said that, under the NLRA, someone cannot be both an employee and an employer. ${ }^{255}$ Foremen, he claimed, are the employer's "arms and legs" in executing its labor policies. ${ }^{286} \mathrm{He}$ also argued that the reasoning of the majority would compel an employer to bargain not only with foremen but also with supervisors, managers, vice presidents and presidents, indeed everyone on the payroll except directors. It would transform the employer-employee divide into one between the "operating group on the one hand and the stockholder and bondholder group on the other" rather than one between management and labor. ${ }^{257}$ Furthermore, he claimed, if foremen were in bargaining units with employees, the employer would be confronted with problems of conflicting loyalties. To avoid this, he argued that those who "represent or act for management on labor policy matters" should be excluded from the coverage of the NLRA. ${ }^{258}$

Douglas' position eventually carried the day. In 1947, numerous amendments to the NLRA were proposed, several of which aimed to overturn Packard by excluding supervisors from the protection of the NLRA. ${ }^{289}$ Senator Taft, one of the co-sponsors of the amendments, explained the need for the supervisory exclusion:

$2 s s 330$ U.S. 485 (1947).

254 Id. at 489.

235 Id. at 495 (Douglas dissenting).

$2 s 6$ Id. at 496.

${ }^{257}$ Id. at 494.

288 Id. at 500 .

${ }^{258}$ See, e.g., H.R. 3020, 80th Cong., 1st Sess. (Apr. 10, 1947) in 93 Cong.Rec. 3318 (Apr. 10, 1947), and S. 1126, 80th Cong., 1st Sess., in 93 Cong.Rec. 3580 (Apr. 17, 1947). Both Houses of Congress had made an earlier attempt to overrule the NLRB's position in Packard. That bill, called the Case bill, passed both houses, but was defeated by a Presidential veto. See Labor Management Relations Act, H.Rep.No. 245, 80th Cong., 1st Sess. 14 (April 11, 1947), reprinted in 1 Legislative History of the Labor Management Relations Act, 1947 304-05 (1948) ("Legislative History"). 
It is felt very strongly by management that foremen are part of management; that it is impossible to manage a plant unless the foremen are wholly loyal to the management. We tried various in-between steps, but the general conclusion was that they must either be a part of management or a part of the employees . . . . The committee felt that foremen either had to be a part of management and not have any rights under the Wagner Act, or be treated entirely as employees, and it was felt that the latter course would result in the complete disruption of discipline and productivity in the factories of the United States. ${ }^{260}$

The original House version of the bill had a broader supervisory exclusion than did that of the Senate, which would have excluded only individuals of the rank of foremen or higher. ${ }^{261}$ In joint conference, a final bill was framed, which was passed by both Houses and, despite a presidential veto, became the Taft-Hartley Amendments to the National Labor Relations Act. It contained the Senate's version of the supervisory exclusion. ${ }^{262}$

${ }^{260} 93$ Cong. Rec. 3836 (Apr. 21, 1947), quoted in Texas Co. v. National Labor Relations Board, 198 F.2d 540, 543 (9th Cir. 1952) (the Texas Co. opinion cites to the incorrect page of the Congressional Record). In a similar vein, the Senate Committee Report on the proposed bill said:

It is natural to expect that unless this Congress takes action [to exclude supervisors from the coverage of the NLRA], management will be deprived of the undivided loyalty of its foremen. There is an inherent tendency to subordinate their interests wherever they conflict with those of the rank and file. As one witness put it, "Two groups of people working on parallel lines eventually find a parallel interest."

Federal Labor Relations Act of 1947, S.Rep.No. 105, 80th Cong., 1st Sess. 5 (April 17, 1947), reprinted in 1 Legislative History at 411 (cited in note 259), quoting 1 Labor Relations Program, Hearings Before the Committee on Labor and Public Welfare S.55 and S.J.Res. 22, 80th Cong., 1st Sess. 239 (1947) (testimony of James D. Francis).

The Report by the House of Representatives Committee on the bill was even more direct:

Management, like labor, must have faithful agents.-If we are to produce goods competitively . . . then, just as there are people on labor's side to say what workers want and have a right to expect, there must be in management and loyal to it persons not subject to influence or control of unions .... .

Labor Management Relations Act of 1947, H.Rep.No. 245, 80th Cong., 1st Sess. 16 (April 11, 1947), reprinted in 1 Legislative History at 307 (cited in note 259) (emphasis in original).

${ }^{281}$ Compare Title 1, §2(12), H.R. 3020, 80th Cong., 1st Sess. (Apr. 11, 1947) 10-11, reprinted in 1 Legislative History at $40-41$ (cited in note 259 ) with Title $1, \S 2(11), \mathrm{S}$. 1126, 80th Cong., 1st Sess. (Apr. 17, 1947) 6, reprinted in 1 Legislative History at 104.

${ }^{262}$ See Labor-Management Relations Act, 1947, H.Conf.Rep.No. 510, 80th Cong., 1st Sess. 35 (June 3, 1947), reprinted in Legislative History at 539. The 1947 amendments as passed thus contained an explicit exclusion for supervisors from the coverage of the NLRA, which now reads:

(3) The term "employee" shall . . . not include . . . any individual employed as a supervisor.... 
The supervisory exclusion thus was directed at those who hold direct authority over other employees. It did not speak about the employee status of others in the management structure. To remedy this oversight, the NLRB developed its own doctrine, called the managerial exclusion, which was directed at non-supervisory management personnel. ${ }^{263}$ This exclusion was applied to employees who were "allied with management,"284 or who "formulate and effectuate management policies."285

While the managerial and supervisory exclusions may appear to apply only to employees high up in the corporate structure, ${ }^{268}$ they have relevance for lower level employees as well. In 1980, the Supreme Court applied the managerial exclusion to preclude unionization amongst professional employees who collectively exercise decision making power over some aspects of their work. The case, N.L.R.B. v. Yeshiva University, ${ }^{267}$ has lead many to question the possibility of reconciling labor participation and collective bargaining. ${ }^{268}$ The reasoning of this decision is worth recounting in detail because it potentially affects efforts of other groups of employees to obtain the kinds of collective decision making power enjoyed by the Yeshiva faculty. That is, if read broadly, the Yeshiva decision closes the door to union efforts to achieve decision making

(11) The term "supervisor" means any individual having authority, in the interest of the employer, to hire, transfer, suspend, lay off, recall, promote, discharge, assign, reward, or discipline other employees, or responsibly to direct them, or to adjust their grievances, or effectively to recommend such action . . . .

29 U.S.C. $\S \S 152(3)$ and (11).

${ }^{263}$ The Board first held that management employees were not entitled to the protections of the Act in Denver Dry Goods, 74 N.L.R.B. 1167, 1175 (1947).

204 Swift \& Company, 115 N.L.R.B. 752, 753-54 (1956).

${ }^{285}$ Bell Aerospace Co., 416 U.S. at 288, quoting Palace Laundry Dry Cleaning, 75 N.L.R.B. at 323 n.4. The issue in Bell Aerospace was whether the NLRB could reinterpret its managerial exclusion narrowly so as to exclude only employees involved in formulating and implementing the employer's labor relations policies. 416 U.S. at 272. The Court rejected this argument, insisting instead that the NLRB continue to apply the broader form of the exclusion. Id. at 289.

${ }^{286}$ But see J. Tarrant, Perks and Parachutes: Negotiating Your Executive Employment Contract 14 (1985) (1972 survey by American Management Association reported that nearly half of the line executives questioned said they would welcome a change in the labor laws to compel employers to bargain with management unions).

267444 U.S. 672 (1980).

${ }^{268}$ See, e.g., Karl E. Klare, The Bitter With the Sweet: Reflections on the Supreme Court's "Yeshiva" Decision, 13 Socialist Review No. 71:99, 123 (Sept.-Oct. 1983) (Yeshiva decision demonstrates that "our labor law is founded on the assumption that employee status and self-determination in work are incompatible"); Comment, Industrial Democracy and the Managerial Employee Exception to the National Labor Relations Act, 133 U.Pa.L.Rev. 441, 449-51 (1985) (Yeshiva decision revealed a paradigm of collective bargaining that made it "incompatible with, or destructive of, a cooperative system of decision making"). 
power. ${ }^{269}$

Yeshiva involved efforts by a university faculty to unionize. The university resisted, claiming that the faculty were managerial or supervisory personnel because they exercised considerable control over decision making in their respective schools. ${ }^{270}$ The NLRB, which previously had certified faculty unions on numerous occasions, applied its then customary approach to faculty bargaining units and concluded that the faculty were employees and thus eligible for collective bargaining. The NLRB based its decisions on a three-factor analysis that it had used in other such cases. First, it said that while the faculty had input into important decisions about the operation of the university, its input was collective, not individual. Second, it said that the faculty exercised its power and discretion in its own interest, not that of the university. Last, it said that final authority in the university was vested in its board of trustees, so that faculy input was only advisory. ${ }^{271}$

In the enforcement proceeding, the Second Circuit refused to enforce the NLRB's order. The case went to the Supreme Court on the question of whether the NLRB properly included the faculty in the bargaining unit. The Supreme Court affirmed the Second Circuit's ruling, agreeing that the faculty was managerial. ${ }^{272}$ In applying the managerial exclusion to the Yeshiva faculty, the Court stressed that the faculty was involved in making policy decisions in a number of areas, including course offerings, admissions and matriculation standards, hiring and promotion of other faculty members, teaching methods, and grading policies. "To the extent the industrial analogy applies, the faculty determines within each school the product to be produced, the terms upon which it will be offered, and the customers who will be served." These powers and authorities, the Court said, "in any other context unquestionably

269 Judge Posner has given such an interpretation to the supervisory exclusion in the wake of the Yeshiva decision. In N.L.R.B. v. Res-Care, Inc., 705 F.2d 1461, 1465 (7th Cir. 1983), he wrote that if there were no supervisory exclusion, an employer

could lose control of its work force to the unions, since the very people in the company who controlled hiring, discipline, assignments, and the other dimensions of the employment relationship might be subject to control by the same union as the employees they were supposed to be controlling . . . . We might become a nation of worker-controlled firms.

270 Yeshiva University, 221 N.L.R.B. 1053, 1054 (1975).

${ }^{271}$ Id. By the time the case reached the Supreme Court, the NLRB had dropped the first and third of these arguments, and relied only on the second factor. See 444 U.S. at 685 and n.20.

272 Id. at 682. 
would be managerial."27s Thus, it found them to be managerial in the university setting.

The NLRB's argument emphasized the faculty's interests as professionals, and said that when faculty members engaged in collective decision making about matters like hiring, curriculum and so forth, they were exercising their professional judgment, seeking to further their own professional interests, not the interests of their employer. ${ }^{274}$ The majority rejected the NLRB's argument that the faculty had interests different from, and sometimes in conflict with, the university. It said instead that the goals and interests of the two groups "cannot be separated."275 It stressed that the managerial exclusion was designed to give the employer the "undivided loyalty of its representatives." "Mans "Magerial employees must exercise discretion within, or even independently of, established employer policy and must be aligned with management."277

Ironically, the alleged congruity of goals and interests between universities and their faculties asserted by the majority did not make the problem of divided loyalty disappear. Rather, the Court found that in a university setting the "problem of divided loyalty is particularly acute." ${ }^{278}$ It reasoned that a university needs the expertise of its faculty to make and implement its policy, yet it lacks the sanctions normally used to obtain it. Unlike middle-level managers in industry, who are held accountable for their performance by means of various employment sanctions and incentives, university faculty are insulated from the usual employer carrots and sticks by the traditional systems of collegiality and tenure. ${ }^{279}$ Thus, the Court said, the employer needed to prevent unionization in order to ensure faculty loyalty.

A dissent by Justice Brennan emphasized that faculty members are expected to use their independent professional judgment on their own behalf, not to implement university policies. He denied the majority's claim that faculty members were "true repre-

273 Id. at 686 and $n .23$.

274 Id. at 688 . The NLRA explicitly includes professionals within the category of "employee," at least since the 1947 amendments. See National Labor Relations Act $\S 2(12)$ and 9(b), 29 U.S.C. $\S \S 152(12)$ and 159(b). Thus the NLRB argued that the authority of the Yeshiva faculty was a natural consequence of their duties as professionals, not an indicia of managerial status.

${ }^{278} 444$ U.S. at 688.

278 Id. at 682 .

277 Id. at 683 .

278 Id. at 689 .

${ }^{279}$ Id. at $689-90$. 
sentatives of management."280 $\mathrm{He}$ also pointed out that universities have dual authority structures, in which an administrative hierarchy makes decisions concerning the interests of the institution as a whole while the faculty merely makes decisions regarding educational policy. Thus, Brennan argued that faculties do not have the kind of near omnipotent power that the majority claimed for them. ${ }^{281}$

Despite the disagreement between the dissent and the majority about the nature of the modern university and about the "true" role of a faculty, there were several points of agreement. First, both shared a belief in the criteria to use to determine who is an employee and who is a member of management. Brennan, like the majority, stated that "[ $t]$ he touchstone of managerial status is thus an alliance with management."282 Also, they agreed that the purpose of the managerial exclusion is to provide management with "undivided loyalty."28s The majority and the dissent merely disagreed about the application of those principles to the facts of the Yeshiva case.

The Yeshiva decision suggests serious limitations on the ability of workers or unions to achieve power in management under the current labor law regime. Its apparent implication is that when a group of employees achieves substantial power over their own work and a substantial role in decision making about production, they will be deemed to be managerial and thus ineligible for collective bargaining. It also suggests that the more power employees collectively attain, the more likely it is that they will be excluded from the coverage of the NLRA. Indeed, this latter suggestion is not mere speculation. In College of Osteopathic Medicine, decided two years after Yeshiva, the NLRB held that faculty members who achieved some degree of decision making power through the very process of unionizing and collective bargaining had made themselves managerial, and thus had to be decertified as a bargaining unit. In response to the union's objection that it should not be able to "bargain itself out of the protections of the Act," the NLRB said it had to decide questions of employee status on the basis of the extent of managerial authority, not "the manner in which such authority was obtained."284

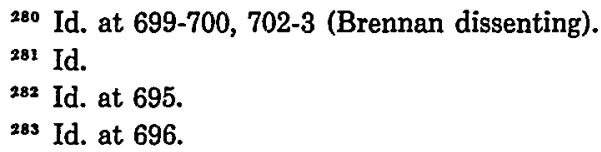


While Yeshiva, together with College of Osteopathic Medicine, might indeed suggest that employees cannot attain significant decision making power under the NLRA, the case law to date is subject to a different interpretation. The application of the managerial exclusion to collective decision making has been limited to unionization of professionals. ${ }^{285}$ However, the reasoning of Yeshiva is not so easily confined. ${ }^{288}$

In order to understand the Yeshiva decision and its implications for labor participation in management, it is necessary to look more closely at the Court's concern with preventing divided loyalty on the part of the faculty members. Divided loyalty, say both the majority and the dissent, is only a danger for those employees who are "aligned with management." danger is never spelled out, the concern is the other side of the conflict-of-interest coin that arises when employees are on corporate directorates. It too is a boundary problem. And, as with the conflict-of-interest doctrine, the divided loyalty doctrine eschews the question of whether the divergence is one of subjective perception or of objective interests. I explore the nature of these interests and loyalties that are said to conflict, as well as the assumptions about the labor-management relationship embedded in them, in Part IV.

\section{Embedded Assumptions in the Prevaling Approach to Union Participation in Corporate Decision Making}

The NLRB's treatment of labor participation in the areas of employee stock ownership, union participation on boards of directors, and direct employee decision making and control share two common themes. First, the case law in all three areas assumes that the categories of "management" and "labor," of "owner" and "employee," must be distinguished and that the distinction must be

616,627 (7th Cir. 1985) (finding university faculty to be managerial notwithstanding claim that managerial authority derived from collective bargaining agreement).

286 To date, the only group other than academic faculty that have been deemed managers under the Yeshiva standard have been health professionals. See, e.g., FHP, Inc., 274 N.L.R.B. 1141, 1142-43 (1985) (applying managerial exclusion to full time physicians and dentists working in a health maintenance organization).

${ }^{286}$ For example, several courts have held that certain production employees were not managerial because they did not have sufficient decision making authority. See, e.g., N.L.R.B. v. Louisville Gas \& Elec. Co., 760 F.2d 99 (6th Cir. 1985) (pollution control analysts lacked authority over fundamental policy decisions and thus not managerial); Iowa Elec. Light and Power Co. v. N.L.R.B., 717 F.2d 433 (8th Cir. 1983) (quality control decisions are of a technical, not policy, nature).

${ }^{287}$ Yeshiva, 444 U.S. at 695 (Brennan dissenting). 
absolute. Second, the cases rely upon conflict of interest or divided loyalty analyses that are never well explained. The cases assume that conflicts of interest and divisions of loyalty justify, or even require, excluding unions from the forms of power represented by stock ownership, directorships, or direct participation in management, but the existence of the conflict and the nature of the division is never established.

These two themes together account for the labor law's disapproval of union efforts at participation. However, while each theme may have some plausibility, each contains assumptions that cannot be justified. In this Section, I undertake this examination, and conclude that the labor law could dispense with these embedded assumptions, and thereby relax its obstacles to union participation efforts.

A. The Prohibition Against Co-Mingling: The Embedded Categories of Employer and Employee

The NLRB uses the statutory category of "employee" to exclude employees from bargaining units and to disqualify unions from representation when they are in a position to exercise decision making power. Employees, according to the NLRB, are people who by definition do not exercise power through stock ownership, board of director membership, or collective participation. By the logic of tautology, the NLRB thus justifies its hard boundaries in the doctrines.

In order to evaluate this approach to participation, it is necessary to look beyond current definitions and the logic used to support them. The NLRB's prohibition against co-mingling expresses a belief that there are inherent functions of management and inherent functions of labor, and that management and labor must inevitably be separate for production to take place. This is a naturalist approach to industrial relations, a form of argument that derives conclusions about permissible social roles from posited natural essences. ${ }^{288}$

In this century, most industrial relations writing has contained an implicit notion that management and labor each perform different functions in the production process and that for there to be any production at all, certain functions must be performed. The approach, which I call "industrial relations functionalism," defines labor and management functionally, and then uses these functions

${ }^{288}$ See P.F. Strawson, Skepticism and Naturalism 37-50 (1985). 
to support various conclusions about what roles each should play and how the two groups should interact. ${ }^{289}$ The industrial relations functionalist imperative is that there must be management to decide overall policy, supervisors to direct the work force, and labor to perform the directed tasks. Having posited a management, a supervisory, and an employee function, the approach also posits a permissible union role, but only of a residual and derivative type. The union role is to obtain protection and input for employees in ways that do not interfere with the management or supervisory functions.

Implicit in the functionalist approach is the assumption that for the functions to be performed properly, they must be performed by different actors. That is, the various functions must be differentiated..$^{200}$ Because these functions must all be performed, and because labor's and management's functions must be differentiated, they cannot be commingled.

This way of thinking about labor and management had its origins in the late nineteenth and early twentieth centuries. In that period, a number of industrial engineers addressed the problems of control, power, and productivity in industry, and developed systems for what they called "rationalizing" the labor process. ${ }^{291}$ Of

${ }^{289}$ Industrial relations functionalism is typified by Neil W. Chamberlain in The Union Challenge to Management Control (1948). It is also found in a more generalized form in structural-functionalist sociology, developed by Talcott Parsons. For example, Parsons wrote of the social division of labor:

Every function at all well established in the economic division of labor comes to involve institutionally defined roles such as those of "banker," "business executive," "craftsman," "farmer," or what not. In connection with such a role there is a pattern of institutionally defined expectations, both positive and negative. Certain of these economic roles involve institutional authority such as that of an employer in the role of supervisor over his workers.

Talcott Parsons, The Motivation of Economic Activities, in Talcott Parsons, Essays in Sociological Theory 50, 55-56 (rev. ed. 1954).

280 Parsons posited a need for functional definition and functional separation in complex social organizations. He argued that all social systems and subsystems are organized to solve four major function problems, "with respect to which they differentiate." These are the integration, goal attainment, adaptation, and tension management functions. These four functional categories apply at all levels of structural organization, and all functions must be performed at every level. The more complex the social system, the more necessary it is that the functions be differentiated, differentiation being a form of adaptation for complex social systems. Talcott Parsons, General Theory in Sociology, in Robert K. Merton, Leonard Broom, and Leonard S. Cottrell, Jr., eds., Sociology Today 3, 4-8 (1959).

${ }^{281}$ Milton J. Nadworny, Scientific Management and the Unions 1-13 (1955), (describing efforts of late nineteenth century "management engineers"); Samuel Haber, Efficiency and Uplift 18-20 (1964) (describing late nineteenth and early twentieth century "systemizers" who aimed to reorganize shop management in order to make profitable and orderly arrangements). 
these, Frederick Winslow Taylor is the best known for his system, called "scientific management." Scientific management was perhaps the most detailed and far-sighted of the various work rationalization systems of the era, which all consisted of techniques to break the hold on the production process that was then being exercised by skilled workers. ${ }^{202}$ The engineers advocated a radical separation of thinking from doing-a separation between the conceiving and directing of tasks and the executing of tasks. ${ }^{293}$ These systems were designed to solve the problem of labor discipline and to enhance worker productivity. ${ }^{204}$

The Taylor system of scientific management consisted primarily of three elements. ${ }^{295}$ First, Taylor advocated paying workers according to a system of "differential piece rates," so as to give faster workers an incentive to out-perform the others. Second, he advocated systematic time study so that the work of each laborer could be measured individually. Third, he insisted that all thinking and planning work be taken away from the laborers and concentrated in a planning department, removed from the shop floor. ${ }^{286}$ It is the

${ }^{202}$ As Taylor said:

Now, in the best of the ordinary types of management, the managers recognize frankly the fact that the 500 or 1000 workmen, included in the twenty to thirty trades, who are under them, possess this mass of traditional knowledge, a large part of which is not in the possession of management. The management, of course, includes foremen and superintendents, who themselves have been in most cases first-class workers at their trades. And yet these foremen and superintendents know, better than any one else, that their own knowledge and personal skill falls far short of the combined knowledge and dexterity of all the workmen under them.

Frederick Winslow Taylor, The Principles of Scientific Management 32 in Frederick Winslow Taylor, Scientific Management (1911). Taylor directed much of his theory toward taking this knowledge about production away from the workers and placing it with management. See id. at 35-38.

${ }^{203}$ See Haber, Efficiency and Uplift at 24-25 (cited in note 291). ("The discovery of a science of work meant a transfer of skill from the worker to management and with it some transfer of power").

294 For a general discussion of Taylorism and late nineteenth century theories of work rationalization and their impact on industrial relations, see Katherine Stone, The Origin of Job Structures in the Steel Industry, in Richard C. Edwards, Michael Reich, and David M. Gordon, eds., Labor Market Segmentation 27 (1975).

${ }^{295}$ See Taylor, Principles of Scientific Management at 118-22 and 129-130 (cited in note 292).

${ }^{206}$ Frederick Winslow Taylor, Shop Management 55, 58, $98-99$ (1911), in Taylor, Scientific Management (1911) ("Shop Management") ("All possible brain work should be removed from the shop"). See id. at 66 ("Establishing a planning department merely concentrates the planning and much other brainwork in a few men especially fitted for their task"). See also Taylor, Principles of Scientific Management at 122-23 (cited in note 292).

The planning department, according to Taylor, was only the first step in a detailed differentiation of function which he considered necessary for efficient production. He also urged that management itself be organized along functional lines, with the jobs of supervi- 
last aspect of scientific management that underlies the hard boundaries so prevalent in industrial relations thinking today. ${ }^{297}$

Taylor insisted on the transfer of all thinking work from the workers to management, and its removal from the shop floor, because he claimed that when workers held a monopoly of knowledge about production, they were able to control the pace of work and thus limit production. ${ }^{288}$ The planning department, like time and motion study, was designed to reduce the necessary skill level of the worker and vest knowledge about production exclusively with management.

Just as 'Taylor was adamant that the workers' hold on knowledge be dislodged, so too was he adamant that the management function and the laborer's function could not be shared. As he wrote:

In any executive work which involves the cooperation of two different men or parties, where both parties have anything like equal power or voice in its direction, there is almost sure to be a certain amount of bickering, quarreling, and vacillation, and the success of the enterprise suffers accordingly. . . . Broadly speaking, in the field of management there are two parties - the superintendents, etc., on the one side and the men on the other, and the main questions at issue are the speed and accuracy with which the work shall be done. . . . It is chiefly due, under the old systems, to this divided control of the speed with which the work shall be done that such an amount of bickering, quarreling, and often hard feeling exists between the two sides. ${ }^{298}$

His solution was clear role definition for each group and absolute separation between them.

The command of scientific management to sever thinking from

sion and management subdivided. Taylor, Shop Management at 99. Supervision should be divided among four types of bosses-gang bosses, speed bosses, inspectors, and repair bosses-and management should be divided among four types of managers in the planning department-routing clerk, instruction card clerk, time and cost clerk, and shop disciplinarian. Id. at 99-104 (describing tasks of each type of functional foreman). The result of this "functional management," he claimed, was to relieve all workmen and foremen of the work of planning. Id. at 98.

${ }^{287}$ See Harry Braverman, Labor and Monopoly Capital 124-37 (1974), for a detailed description and critique of the differentiating and "deskilling" aspects of Taylorism.

${ }^{298}$ Taylor, Shop Management at 32-34 (cited in note 296). See also Judith A. Merkle, Management and Ideology 30 (1980) (describing Taylor's efforts to break skilled workers' monopoly on expertise).

${ }_{289}$ Taylor, Shop Management at 43-44 (cited in note 296). 
doing and managing from laboring was neither self-evident nor simple to execute. Workers and unions resisted because they saw it as depriving them of their skills and their dignity, as well as their power in the production process. ${ }^{300}$ Lower level managers often resisted because they saw their own authority diminished. ${ }^{\text {on }}$ Thus Taylor and his followers gave their client businessmen techniques to overcome the resistance of the foremen, which they saw as necessary to the success of their program. They counselled that front-line supervisors had to be reeducated in order to play a constructive role in a scientifically managed firm. ${ }^{302}$ Where previously foremen had played the role of lead worker, or "straw boss," Taylor said they had to learn the role of directing, supervising, and disciplining others. Foremen, many of whom were first rate workers themselves and who prided themselves on their work skills, had to be taught not to perform production work, but to become bosses instead. Thus foremen's training, designed to teach them these new roles, became a regular feature of scientific management. ${ }^{303}$

Taylorism had an enormous impact on the way people in the twentieth century have thought about industrial relations. ${ }^{304}$ The radical separation of thinking and doing that he advocated lies at the heart of the conception of the industrial world in which labor and management perform entirely separate functions. However, this conception is not and never was a description of the workplace. Rather, as the history of scientific management demonstrates, the conception underlies a consciously constructed world, a world which Taylor and his followers worked hard to bring

soo See Jean Trepp McKelvey, AFL Attitudes Toward Production 1900-1932 17 (1952) (Samuel Gompers objected to scientific management because it robbed the worker of his creative input and because the wages were not increased in proportion to productivity); Haber, Efficiency and Uplift at 66-68 (cited in note 291) (describing labor movement opposition to scientific management); Stone, The Origin of Job Structures, in Edwards, Reich, and Gordon, Labor Market Segmentation at 45 (cited in note 294) (describing worker opposition to Taylorist wage policies); David Montgomery, Workers' Control in America 101-108 (1979) (describing workers' response to "rationalized industry").

${ }^{301}$ See, e.g., Taylor Society, Scientific Management and American Industry 444-445 (1929) (foremen opposed scientific management because they saw in it a reduction in their authority).

${ }^{302}$ See Taylor, Shop Management at 104-05 and 139-43 (cited in note 296).

sos See Stone, The Origin of Job Structures in Edwards, Reich, and Gordon, Labor Market Segmentation at 58-60 (cited in note 294). For a prescriptive account of how to manage a factory according to Taylor's principles, see $\mathrm{H}$. Church, The Success and Practice of Management (1914).

sos For descriptions of the impact and pervasiveness of Taylorism, see David Montgomery, Workers Control at 101 (cited in note 300); Merkle, Management and Ideology at 11 (cited in note 298). 
about. ${ }^{305}$ Its adoption by the theorists of industrial relations bespeaks the success of scientific management, not only in shaping the workplace, but also in shaping our ideas about work. ${ }^{308}$

One sees functionalist rationales and justifications in much of the industrial relations and labor law scholarship in this century. For example, Neil Chamberlain, one of the most influential scholars of industrial relations in the post-war era, developed a theory of "functional integration" for management and labor. In his book, The Union Challenge to Management Control, Chamberlain argued that union demands for participation in management could be contained, and management's hostility to unions could be alleviated, if they both correctly understood the functions of management in the modern corporation. He then presented a typology of management of the modern corporation in which he distinguished several levels of management, described and differentiated by what he calls the three basic management functions: direction, administration, and execution. In this typology, the highest stage of management, directive management, is ultimately defined by legal duties imposed by state and federal law. Directive management then imposes further limitations on the discretion of administrative management, which then restricts the prerogatives of executive management. ${ }^{307}$

Within this allocation of discretion and authority in the corporate organization, Chamberlain set out a narrow union role. $\mathrm{He}$ said that a union participates in the directive function to the extent that, through collective bargaining, it joins in forming certain

${ }^{305}$ Ironically, by the early 1920s, at least one management consultant lamented the impact of this feature of scientific management:

We began to separate the shop personnel into thinkers on the one hand and appendages to machines of various kinds on the other; to take out the little remaining human elements and to substitute an impersonal planning department, made up in too many cases from young college graduates with little or no shop experience . . . .

After dehumanizing the shop, so far as consulting with the men actually on the job was concerned, and making the operators into automatons so far as possible, we found much discontent and the lack of interest became very noticeable.

Fred H. Colvin, Labor Turnover, Loyalty and Output 7 (1919).

${ }^{306}$ Many have written about the lasting impact of scientific management as a series of practices reshaping the workplace. See, e.g., Braverman, Labor and Monopoly Capital at 86 (cited in note 297) ("It is impossible to overestimate the importance of the scientific management movement in the shaping of the modern corporation and indeed all institutions of capitalist society which carry on labor processes"). While I agree with this assessment, I am here concerned with another aspect of scientific management and the writings of Taylor: its impact as a set of ideas which have shaped our visions of the workplace and the universe of possibilities in our imagination.

${ }^{307}$ Chamberlain, Union Challenge at 195, 196-197 (cited in note 289). 
policies. This participation typically is exercised only at contract negotiation time. ${ }^{308}$ The union can also participate in the administrative function, but there, he said, it must accept "the requirements of operating within the discretionary boundaries of each frame" and recognize "that higher authority may overrule it."309 And, he said, it may never share in the exercise of the execution function. Chamberlain argued that only if unions recognize these functional imperatives and their role within them, will unions and management be able to coexist peacefully. ${ }^{310}$

A more recent example of industrial relations functionalism is found in a book by the noted industrial relations scholar, Jack Barbash. In his preface to The Elements of Industrial Relations, published in 1984, he wrote:

This book is built around the proposition that industrial relations is not only ideology-it is surely that-but also function. ... [It] is also a mode of interaction or tension which maintains the enterprise organization in sufficient equilibrium to produce goods and services at competitive costs and create useful jobs. This is industrial relations as function. ${ }^{311}$

Barbash, like Chamberlain, defined "management function" and "union function," "\$12 and like Chamberlain, he used that definition to argue the necessity of separation between management and labor. ${ }^{313}$

Justice Douglas echoed these beliefs in his Packard dissent when he said that the reason to prohibit foremen from unionizing is that the line between management and labor would be "obliterate[d]." 14 He said, "I find no evidence that one personnel group may be both employers and employees within the meaning of the

s08 Id. at 198, 203.

309 Id. at 202.

${ }^{310}$ Id. at 202-203.

s11 Jack Barbash, The Elements of Industrial Relations ix (1984).

312 Barbash defines management function as the "pursuit of managerial efficiency" and as imposing "cost discipline," which consists of "systematic planning, direction, and control of enterprise decisions." Id. at 17. He defines the union function as bargaining over the price of labor. Id. at 54-58. "[I]n an industrial society ruled by scarcity of resources somebody has to perform the management function, and when that happens, somebody or some group will perform the union function." Id. at ix.

s1s Barbash concludes that unions avoid co-responsibility with management and codetermination because they are the negation of the adversarial process which the two functions entail. Id. at 59-63.

sis Packard, 330 U.S. at 494-96 (Douglas dissenting), discussed at notes 253-258 and accompanying text. 
Act."315 In particular, "[t]rade union history shows that foremen were the arms and legs of management in executing labor policies."318 Thus he asserted that the absolute separation between management and labor is as natural and necessary as the human body. $^{317}$

By understanding the logic of functionalism in industrial relations, it is possible to make sense of the NLRB's insistence on maintaining effective boundaries between management and labor. We can understand why it is that the more likely employee-owners exercise decision making power, especially in regard to labor relations, the more important, from the NLRB's point of view, it is to exclude them from collective bargaining. The exercise of such powers blurs, if not extinguishes, the boundaries that the functionalist approach requires. If one believes that production cannot be accomplished without the functions being performed and differentiated, then the boundaries are necessary and inviolable.

However, as the history of scientific management demonstrates, industrial relations functionalism is constructed and contingent, rather than natural and necessary. The separation of function on which the theory relies was an ideological construct, implemented with greater or lesser success in different enterprises, with the explicit aim of reconstructing and recreating the industrial world.

Furthermore, the functionalist conclusion that labor and management must be kept entirely separate is only as strong as the ability of the theory to specify the function of each group. That is, the approach requires a convincing definition of the functions of management to support the rest of its descriptive and prescriptive ramifications. Yet every effort to carve out certain functions as necessarily and exclusively management functions is belied by experience. Countless examples of all kinds of heretofore "management functions" have been performed by labor, without production grinding to a halt or enterprises self-destructing. Examples abound of small work groups making production decisions collectively on the shop floor in the Swedish auto industry, of quality circles in Japanese electronics companies involving workers in high level management decisions, of German union officials sitting on boards of directors. And, as I have noted, American unions and businesses

317 See also Senator Taft's rationale for the supervisory exclusion in the 1947 amendments to the NLRA, discussed at note 260 and accompanying text. 
have made numerous similar efforts. All of these contemporary events demonstrate that labor can, and sometimes does, play many roles in the corporate structure. Thus no simple segregation of function can be justified on the basis of the way things have to be. Even Chamberlain's unparalleled effort to carve out definitions of functions which are immutably management seems dated today in light of the tremendous experimentation in worker participation we have witnessed in the past five years.

Lacking a convincing account of management function, the functionalist argument is weakest at its core. Indeed, many of the efforts to specify the function are ultimately circular in that the description of the function contains within it the conclusion about how power between labor and management should be distributed. $^{318}$ Even Chamberlain's elaborate specification of management function has no greater grounding in logic or science than its argumentative power to persuade unions to accept the place to which his categories, at the outset, assign them.

If there is no inherent and independent function of management, then there is no reason why either management or labor need be role-bound by it. And if neither is bound by any particular role, there is no reason not to permit unions to exercise functions heretofore exercised by management. Consequently, there is no reason to disqualify employees from collective bargaining simply because they own stock, either individually or collectively, or hold positions of power on boards of directors. Rather, if we believe that employee participation is desirable, then "stock power" or "director power" should not be reasons to deny employee-owners and employee-directors the protection of the labor laws. Neither management nor labor need be frozen in function. That is, if we see that embedded in the NLRB's definition of "employee" and "management" are normative claims about distributions of power, then we can imagine many different power relations between management and labor within the existing regulatory system.

\section{B. Conflict of Interest and the Implicit Theory of the Firm}

The second theme in the NLRB's treatment of union participation efforts is that of conflict of interest and divided loyalty. These rationales are invoked to disqualify unions which sit on

\footnotetext{
s18 See, e.g., Barbash's definition of management function, cited in note 312 , as including control over decision making. For a criticism of this aspect of functionalism in general in the social sciences, see Anthony Giddens, Studies in Social and Political Theory 109-112 (1977).
} 
boards of directors or which represent employees who exercise significant power in decision making. While there may be some surface level plausibility to the conflict of interest rules, they do not bear careful scrutiny.

The NLRB has never satisfactorily explained the precise nature of the disabling conflict of interest or divided loyalties when it applies these doctrines. At times, the NLRB's discussion of these doctrines suggests that it is concerned about a subjective conflict-a dilemma for employees who are placed in a position where they must act in the face of two incompatible commitments. For example, in the area of union membership on boards of directors, a subjective conflict might be experienced by a union-negotiator who faced a union-dominated board of directors. In that situation, the conflict of interest doctrine reflects a concern that the negotiator will be less than forceful in promoting the interests of the union members. ${ }^{319}$

However, a concern about a subjective conflict of that type could presumably be addressed through the mechanisms of disclosure and consent. That is, if the union members knowingly choose to place representatives on the board of directors, and thus choose to take a risk that its union negotiators might be compromised in their commitment to furthering the membership's interests at the bargaining table, the members should be free to do so. Any union membership making such a choice, presumably, has decided that it has more to gain from sharing corporate power on the board of directors than it has to lose from the risk of betrayal. ${ }^{320}$ That the NLRB does not permit consent to vitiate the conflict of interest suggests that it is not concerned about a subjective conflict, but rather about some other kind of conflict of interest. ${ }^{321}$

\footnotetext{
s19 See, e.g., Centerville Clinics, Inc., 181 N.L.R.B. at 140 (union disqualified because, among other things, there were "temptations" created by the union's dual role); St. Louis Labor Health Institute, 230 N.L.R.B. at $182 \&$ n. 9 (concern that union president will be subject to "subtle pressures" that would interfere with his obligation to represent the union's membership). See also Child Day Care Center, 252 N.L.R.B. at 1177 (union must approach bargaining table with "single-minded purpose of protecting and advocating the interests of employees").

${ }^{320}$ Any corruption in the process by which the union makes such a choice is policeable through the duty of fair representation. See Ford Motor Co. v. Huffman, 345 U.S. 330, 33738 (1953), and the union democracy rules of the Labor-Management Reporting and Disclosure Act, 29 U.S.C. $\$ \S 401-531$.

${ }^{321}$ Another indication that the conflict of interest is not primarily about the union officials' subjective experience is the doctrine holding that where the union is disqualified by virtue of a conflict, the employer is automatically in violation of $\S 8(\mathrm{a})(2)$. See, e.g. Medical Foundation of Bellaire, 193 N.L.R.B. at 64-65 (1971); Child Day Care Center, 252 N.L.R.B. at 1177 . Presumably the reason why the employer, by bargaining with a disqualified union,
} 
The divided loyalty concern that justifies the application of the managerial exclusion to direct collective employee participation in management is similarly not a concern about subjective loyalties. Rather, as the Supreme Court said in Yeshiva, the reason that the problem of "divided loyalty [was] particularly acute" for faculty members was that, given the tenure system, the university had none of the conventional means to ensure real faculty loyalty. ${ }^{322}$ The loyalty that the Court feared would be divided if faculty members unionized was thus not a loyalty rooted in anyone's subjective views.

Another possible interpretation of the conflict of interest and divided loyalty rules is that both address a conflict which arises from incompatible and irreconcilable fiduciary duties imposed by law. Such a conflict is most evident when a union officer serves as a director. ${ }^{323}$ Both union officers and corporate directors are subject to fiduciary duties from different sources. ${ }^{324}$ In theory, the director owes a duty of loyalty to the welfare of the corporation, while the union officer owes a duty to its membership alone. These two duties might easily conflict.

However, this interpretation of the conflict of interest rules is problematic. The fiduciary duties of both union officers and of corporate directors are creatures of positive law, and the scope and content of such duties could be redefined in such a way as to make them consistent. ${ }^{325}$ Whether there is to be a disabling conflict of

has violated $\S 8(a)(2)$ is that it bargained with an illegitimate union. The $\S 8(a)(2)$ violation thus arises without regard for whether the union has majority employee support-it is a strict liability offense.

${ }_{322}^{324}$ U.S. at 689, discussed at notes 269-289 and accompanying text.

s2s See, e.g., Medical Foundation of Bellaire, 193 N.L.R.B. at 64 (union disqualified when the union has "direct and immediate allegiances which can fairly be said to conflict with its function of protecting and advancing the interests of the employees it represents").

324 Section 501(a) of the Labor-Managment Reporting and Disclosure Act, 29 U.S.C. $\$ 501$, defines the fiduciary duties of union officers. For fiduciary duties of members of boards of directors, see William Meade Fletcher, 3 Cyclopedia of the Law of Private Corporations $\S \S 838-40$ (perm.ed. 1986).

s2s Corporate law has gone far toward reconciling similar conflicts in other contexts. For example, no conflict of duty prohibits representatives of other interests, like banks, from sitting on the boards of the corporations to which they have made substantial loans. Indeed, in the case of banks, it is precisely because of the loan that the bank wants to have a representative on the board, and it is assumed by all that the bank representative protects the interests of the bank. Similarly, many conflicts of interest between management and stockholders can be shielded from attack by blanket prior stockholder approval. See Elliott J. Weiss, Disclosure and Corporate Accountability, 34 Bus. Lawyer 575, 594-95 and n.69 (1979). See also Note, Serving Two Masters: Union Representation on Corporate Boards of Directors, 81 Colum.L.Rev. 639, 656-658 (1981) (conflict of interest problems that arise when union representatives sit on a corporate board are similar to those where companies 
interest when a union representative sits on a corporate board, or when a union occupies a majority of seats on a corporate board, is a function of how the NLRB defines a union's duties. ${ }^{326}$ At the same time, the legality of any action by a member of a board of directors is a function of how a court defines the relevant state's corporate laws. ${ }^{327}$ Nothing inherent in the labor laws or the corporate laws dictates that the fiduciary duties could not be reconciled. ${ }^{328}$

Thus the conflict of interest that prevents unions from exercising power on boards of directors or through direct participation is not simply a matter of conflicting legal fiduciary duties. However, it is possible that the conflict arises from some broader, less well articulated sense of what the duties of employees and owners, and of unions and managers, should be. If so, embedded in the conflict of interest rules is an inchoate view of what the corporation is, and what duties and loyalties these various individuals and groups have and ought to have.

I believe that there is a view of the corporation embedded in the conflict of interest and divided loyalty problem which accounts for the existence of this alleged conflict. It is a view that says that there is such a thing as a corporate entity as a whole, separate from its constitutive parts. ${ }^{329}$ In this view, unions represent one narrow and particular part of the enterprise, while those with power-be they board members, owners, or managers-need to look out for the general interest of the enterprise as a whole. The conflict; then, is between actions which further the narrow and particular union interest and actions which further the general corporate interest.

with common directors transact business with each other).

${ }^{328}$ See, e.g., McCormick, 15 U.Mich.J.L.Ref. at 254-255 (cited in note 29) (NLRB generally assumes that a union representative on a corporate board remains loyal to the union). ${ }^{327}$ See, e.g., Smith v. Van Gorkom, 488 A.2d 858 (Del.Supr. 1985) (defining content of duty of care under Delaware law).

${ }^{328}$ See Note, Labor Unions in the Boardroom: An Antitrust Dilemma, 92 Yale L.J. 106, 112-113 and nn. 27-28 (1982) (citing cases reconciling fiduciary duties under labor and corporate law).

${ }^{328}$ The entity view of the corporation has long roots in American legal history. See John Dewey, The Historic Background of Corporate Legal Personality, 35 Yale L.J. 655 (1926). This view of the corporation has recently become the subject of a larger debate about the nature not only of the corporation, but of legal categories in general. See, e.g., Morton Horwitz, Santa Clara Revisited: The Development of Corporate Theory, 88 W.Va.L.Rev. 173 (1985); William Bratton, The New Economic Theory of the Firm: Critical Perspectives From History (forthcoming) (manuscript on file at the University of Chicago Law Review); Comment, The Personification of the Business Corporation in American Law, 54 U.Chi.L.Rev. 1441 (1987). 
This conception of a narrow union interest in conflict with a general corporate interest comes through in some judicial opinions. For example, in a post-Yeshiva case involving the application of the managerial exclusion to a college faculty, one judge has described the conflict of interest problem as follows:

[T] he policy behind the managerial exclusion is to prevent a conflict of interest. . . . Yet it is important to define precisely what this conflict is. If managerial employees are powerful enough to "effectively control" policy, then they are the employer. Consequently, they can no more divide loyalties between the employer and the union than they could between themselves and the union. Division of loyalties is a problem, then, only because management owes a fiduciary duty to a third party: ownership. Management's duty is to bring together ownership's capital and the employees' labor in order to produce goods and services for the benefit of ownership. This duty cannot be discharged if management allies itself with labor. ${ }^{330}$

The conflict of interest doctrine, seen as a conflict between the union's narrow interest and the corporation's general interest, relies on a particular conception of the corporation and a particular vision of corporate governance. It assumes that the corporation is a black box-a unified entity run by a board of directors and a dayto-day management team that is devoted to implementing the interests of the owner-shareholders. This is the view of the corporation which is embedded in traditional corporate law.

Traditional corporate law assumes that shareholders are the only equity interest in the firm, and that the board of directors is there to express and implement their interests. ${ }^{331}$ By linking decision making power over major issues of corporate policy to equity, traditional corporate law theory says that labor has no role to play in corporate decision making. Instead, it treats labor like suppliers and customers, who contract with the firm but are not of it. ${ }^{382}$

${ }^{330}$ N.L.R.B. v. Lewis University, 765 F.2d 616, 632 (7th Cir. 1985) (Swygert dissenting) (citation omitted) (emphasis in original).

ss1 See Victor Brudney, The Independent Director-Heavenly City or Potemkin Village, 95 Harv.L.Rev. 597, 602 (1982).

ssz See Masahiko Aoki, The Co-operative Game Theory of the Firm 8 (1984) ("Ten years ago, the received Anglo-American legal model of the corporation (the company) was parallel to the neoclassical model of the firm. ... . [I]t took the view that employees were not members of the corporation (the company) and that their rights sprang from the employment contract alone, the terms of which were likely to be determined as a result of collective bargaining"). 
However, there are new theories of the corporation that give a much more rich and complex picture of corporate governance structures, pictures which make more room for a substantial labor voice. Under one of these theories, correctly understood, there is no inconsistency between collective bargaining and labor representation on a board of directors, even if the union has a majority on that board.

1. The Role of Labor in the Theory of the Firm. In 1976, in a pathbreaking article about corporate law theory, Jensen and Meckling ${ }^{333}$ argued that a corporation consists of nothing more than a bundle of contractual arrangements among a variety of parties-customers, suppliers, lenders, investors, managers, and workers. ${ }^{334}$ With this insight, the black box view of the corporation collapsed and the "nexus of contracts" view was born. ${ }^{336}$ Under the "nexus of contracts" view of the corporation, no group has an $a$ priori privileged relation to the entity as a whole. All attempt to use their own particular input and their own type of leverage to strike the best bargain they can. Thus, labor stands formally on an equal footing with all other contenders for power within the concern. ${ }^{336}$ This view, unlike the traditional one, does not rule out a role for labor in corporate governance. Rather, most nexus of contracts theorists are silent on the issue.

One contemporary scholar of the corporation has directly addressed the issue of what role labor should play in this new vision of the corporate structure. Oliver Williamson has used the nexus of contracts view in an attempt to explain all types of contractual arrangements within firms and between firms, including arrange-

${ }^{333}$ Michael C. Jensen and William H. Meckling, The Theory of the Firm: Managerial Behavior, Agency Costs and Ownership Structure, 3 J.Fin.Econ. 305, 311 (1976).

${ }^{334}$ Id. The idea that a firm can be analyzed as a series of contracts had its origins in Ronald H. Coase, The Nature of the Firm, 4 Economica 386, 391 (1937), where Coase argued that a firm is a substitute for discrete market contractual arrangements. The modern theorists differ from Coase in their insistence that the firm is not a substitute for discrete contracts but rather it is such a series of contracts.

${ }^{335}$ Numerous scholars adopted, applied, and developed the nexus of contracts perspective since the initial Jensen and Meckling article. See, e.g., Daniel R. Fischel, The Corporate Governance Movement, 35 Vand.L.Rev. 1259, $1261-62$ (1982); Barry D. Baysinger and Henry N. Butler, Corporate Governance and the Board of Directors, 1 J.L.Econ. \& Org. 101, 104-05 (1985). For a discussion of this development in corporate law theory and its implications for substantive corporate law, see Bratton, The New Economic Theory of the Firm (cited in note 329 ).

${ }^{336}$ See Roberta Romano, Metapolitics and Corporate Law Reform, 36 Stan.L.Rev. 923, 964 (1984) (discussing adversary model of the corporate board in which the board replicates a legislature where diverse interests group confront each other and form coalitions to further their conflicting desires and ends). 
ments between labor and management, as efforts to achieve efficiency and to minimize transaction costs. ${ }^{337}$ In 1984, Williamson applied his "transactional efficiency" approach to the problem of corporate governance. ${ }^{338}$ There he proposed a model to decide which constituencies in a corporation should be on the board of directors based on a typology of three different relationships a group can have to a corporation. The three relationships are distinguished by the investment each group has made-in particular, the degree to which a group's investment is special-purpose and transaction-specific on the one hand, or generalizable on the other. ${ }^{33 \theta}$ Williamson denotes the three types of investments as Nodes A, B, and $\mathrm{C}$.

Node A in Williamson's typology consists of those investors whose transactions use "general-purpose technology." ${ }^{340}$ These investments are generalizable in that the investors can always and easily withdraw their assets and redeploy them elsewhere. For these transactions, he argues, discrete market contracting suffices. Such investors do not need board representation to protect their interests because they are adequately protected by market forces. $^{341}$

Nodes B and C, on the other hand, consist of those investors who have made substantial investments of an asset-specific kind. Such persons have investments which are tailored to the special purpose of the particular firm or transaction. Their investments cannot be redeployed in the market, or at least not at the same rate of return that they could have obtained initially. ${ }^{342}$ Such in-

337 Oliver E. Williamson, Economic Institutions of Capitalism (1986). Williamson builds his argument from two assumptions about human nature-that human beings possess bounded rationality and act opportunistically - and one fact about transactions-that some require the development or deployment of transaction-specific investments. He argues that many marketing arrangements and industry structures can be explained on efficiency grounds once these qualities of people and transactions are properly understood.

3ss Oliver Williamson, Corporate Governance, 93 Yale L.J. 1197, 1200-03 (1984). The ideas in Williamson's article were repeated in his subsequent book, The Economic Institutions of Capitalism, and thus the two works will be treated together.

339 "The most important attribute for assessing whether a transaction requires a special governance structure is the degree to which the parties must invest in transaction-specific assets to facilitate the proposed exchange of goods or services. Transaction-specific assets are ones whose value is much greater in the given transaction than in their next-best use or by their next-best user." Williamson, 93 Yale L.J. at 1202.

${ }^{360}$ Id. at 1204. He defines "general purpose technology" as "technology that is useful over a broad range of transactions and therefore involves no exposure of transaction-specific assets ... . Special purpose technology, by contrast, incorporates transaction-specific assets." Id.

34 Id.

342 Id. 
vestors thus depend upon the success of the enterprise and are vulnerable to its failures.

Given the asset-specific nature of their investments, one might think that Node $\mathrm{B}$ and $\mathrm{C}$ investors are the ones who need to be able to protect their investments through representation on boards of directors. However, Williamson distinguishes two categories of special purpose investors-those who have worked out special bilateral safeguards to protect their investments and those who have not. Bilateral safeguards take one or more of three forms:

The first is the realignment of incentives, commonly through some type of penalty for premature termination. The second is the creation of a specialized governance structure to resolve disputes . . . . The third is the introduction of trading regularities that support and signal intentions of continuity. ${ }^{343}$

Williamson says that where asset-specific investments are involved, parties have an incentive to develop such bilateral safeguards, which he also calls "bilateral governance structures," to protect their investments. ${ }^{344}$

Node $\mathrm{C}$ investors are those who have made investments that are asset-specific, but who also have special bilateral governance structures to protect them. Indeed, by Williamson's definition, Node $\mathrm{C}$ investors have precisely enough bilateral safeguards to protect the value of their asset-specific investments at risk. ${ }^{345}$ Thus the asset-specificity of their investment poses no special risk to Node $\mathrm{C}$ investors, and consequently, they need no representation on a board. In fact, Williamson argues that the specialized structures of Node $\mathrm{C}$ investors are better adapted to protection of their needs than is the generalized instrument of participation on a

s43 Id. at 1204-05 (footnotes omitted).

${ }^{344}$ Id. at 1204-06.

315 Id. at 1204. There are serious measurement problems here. By definition, the safeguards compensate for a risk of losing an asset-specific investment. A safeguard cannot "equal" this risk unless it is a compensating monetary benefit triggered by the loss of the investment and equal in amount thereto. One example Williamson gives of such a safeguard is a policy of making severance payments for unwarranted dismissals in the amount of the value of an employees' nonvested pension and other rights. See id. at 1217. However, a severance payment of that type equals the risk only if it wholly compensates not only for forfeited pension benefits, but also for the difficulty of finding comparable substitute employment and the opportunity costs of acquiring the firm-specific human capital in the first place. While this measurement problem may seem surmountable in regard to severance payments, the problem becomes more pronounced when the particular safeguard being measured is not a monetary one, but is instead a governance one, like the arbitration and private ordering system characteristic of collective bargaining. 
board. ${ }^{346}$ Asset-specific investors, therefore, "are better advised to perfect their relation to the firm at the contracting interface at which firm and constituencies strike their main bargain."347

Node B investors, on the other hand, are those whose investments are asset-specific but who enjoy no special bilateral governance structures. Instead, these investors need to be on the board of directors to protect asset-specific investments because the board is, in his terms, a "general purpose control instrument." ${ }^{348} \mathrm{He}$ says that board representation is a governance mechanism which provides information about, and an opportunity to monitor and participate in, management actions in the interest of safeguarding asset-specific investments in the firm. It is a safeguard for those asset-specific investors who have no special bilateral safeguards of their own. ${ }^{348}$

Labor, according to Williamson, falls in the category of Node C-special-purpose investors who have special bilateral governance schemes. ${ }^{300}$ Labor's bilateral governance scheme is "the grievance machinery and associated job structures-ports of entry, promotion ladders, bumping, and so forth."s51 Indeed, it is the private ordering approach to collective bargaining that has come to predominate in the post-war era. Williamson quotes several legal scholars to the effect that collective bargaining has developed into a private ordering system-a privatized, autonomous mini-democracy, in which unions and management govern themselves. He notes that, as part of this mini-democracy, unions and management have created their own dispute resolution mechanisms in the form of grievance procedures and private arbitration. ${ }^{352}$ Thus, his argument for the proposition that labor has a separate bilateral governance mechanism relies on a description of the industrial pluralist framework that has emerged under judicial interpretation of

${ }^{316}$ See id. at 1206. He also argues that it would be expensive to include Node $\mathrm{C}$ investors on the board due to the educational expenses necessary to enable them to participate. Moreover, if Node $\mathrm{C}$ investors gained extra leverage on the board, Williamson warns that problems of opportunism would arise, and other groups might be adversely affected. Id. at 1206-07.

367 Williamson, Economic Institutions at 298 (cited in note 337).

s48 Williamson, 93 Yale I.J. at 1198 (cited in note 338).

349 Id. at 1205-06. Williamson also suggests that if such groups do not have board representation, they will charge a higher price for their investment to reflect added risk.

sso See id. at 1207-09. He refers here only to workers who possess firm-specific skills. Those workers with general purpose skills and knowledge fall into Node A in his schema. See id. at 1207.

s51 Id. at 1208.

${ }^{352}$ Williamson, Economic Institutions at $250-252$ (cited in note 337 ). 
the National Labor Relations Act. ${ }^{363}$ Williamson argues that this framework permits unions to protect the investment of workers adequately, so that board representation is unnecessary, and perhaps undesirable. In essence then, he claims that the collective bargaining system that has emerged under the industrial pluralist interpretation of the labor laws is a substitute for labor involvement in corporate decision making at the board level.

Williamson concludes that there is no need for labor to have seats on a board of directors because it has an adequate alternative mode of protecting itself. ${ }^{354} \mathrm{He}$ contrasts labor's position to that of stockholders who, he says, are situated at Node B. Stockholders are Node $B$ investors because they have asset-specific investments which are of a diffuse character, and which are not up for periodic renewal. ${ }^{355} \mathrm{He}$ claims that these features mean that stockholders are "at an enormous disadvantage in crafting the kind of bilateral safeguards normally associated with node C."358 Thus, he concludes that "the board of directors should be seen as a governance instrument of the stockholders."

${ }^{353}$ Industrial pluralism "is the view that collective bargaining is self-government by management and labor: management and labor are considered to be equal parties who jointly determine the conditions of the sale of labor power." Stone, 90 Yale L.J. at 1511 (cited in note 33).

Williamson relies on my work describing the industrial pluralist view of collective bargaining. See Williamson, Economic Institutions at 250-52 (cited in note 337). However, he misstates my criticism of the private ordering approach to labor relations. He takes issue with a footnote in which he claims I criticize arbitrators because in interpreting the language of the written agreement, they seek to "please the parties." Id. at 251, quoting Stone, 90 Yale L.J. at 1552 and n.238. He argues that labor and management should please themselves because they are the best judges of their own interests. However, this ignores the thrust of my critique of the industrial pluralist interpretation of the labor laws. I criticize the reliance on private ordering for its tendency to individualize workers' problems and frame them in an economistic and invisible way, see Stone, 91 Yale L.J. at 1580, and for its tendency to permit arbitrators to decide cases on the basis of efficiency, stability, and continuity rather than on the basis of hard-won contractual rights. See Stone, 45 Md.L.Rev. at 1008-09 (cited in note 33). These consequences lead me to conclude that the private ordering approach to labor regulation has weakened labor in the post-war era.

${ }^{354}$ Williamson does suggest that in some circumstances it might be desirable to have labor membership on boards for informational purposes only. Williamson, 93 Yale L.J. at 1208-09 (cited in note 338).

sss "[T] investments to effect redeployment." Id. at 1209-10. Williamson acknowledges that individual stockholders can easily sell their shares, thus presumably placing them at Node A. However, he sidesteps this difficulty by saying he is looking at the position of stockholders as a group. Id. at 1210.

${ }^{358}$ Id.

${ }^{357}$ Id. Williamson also acknowledges circumstances in which "[a] banking presence in a voting capacity on the board of directors may be warranted." Id. at 1212. Williamson considers and rejects arguments for granting board representation to suppliers, to customers 
Williamson's conclusion about labor's claims to board representation, and his comparison of that claim with the claim of stockholders, follows from his assumption that labor is situated at Node $\mathrm{C}$ and stockholders at Node B in his schema. His conclusion further assumes that the industrial pluralist framework for labormanagement governance is an adequate bilateral governance mechanism. But, as I have demonstrated above, this assumption is far from the truth. Rather, the labor laws have been interpreted to constrain and limit the ability of unions to protect their members' jobs. Conventional collective bargaining is thus not an adequate bilateral safeguard to protect the asset-specific investments of union members. If corrected for this mistaken assumption, however, Williamson's typology helps us rethink questions of corporate governance and conceptualize a corporation in which labor plays a role.

2. A Slightly Revised Theory of the Firm. Williamson is correct to observe that workers have asset-specific investments in their jobs which make them vulnerable to the fate of their firms. Indeed, workers arguably are more vulnerable to the downside risk of an enterprise than all other constituent groups. Unlike all of the other interested groups, they have the least ability to protect themselves by exit. ${ }^{358}$ There are substantial costs to an individual changing jobs-even when others are available-due to the internal labor market structure of many firms. ${ }^{358}$ Also, individuals who work for an enterprise over time experience an interesting dual effect on their own human capital. On the one hand, they become more valuable to their particular firm and are rewarded, to varying

(except large customers who might have a claim to an informational role), and to the community. See id. at 1212-15.

sss Unlike Williamson, who purports to treat shareholders only as a group, see note 355 , Harold Demsetz, The Structure of Ownership and the Theory of the Firm, 26 J.L. \& Econ. 375, 387-90 (1983), and Baysinger and Butler, 1 J.L.Econ. \& Org. at 106-07 (cited in note 335 ), have attempted to find asset-specificity for the investments of shareholders as individuals. They argue that many stockholders cannot exit easily, particularly family-member stockholders and large institutional investors, because selling would be disloyal or undesirable as a matter of market policy. However, granting for the sake of argument that these particular stockholders cannot readily exit, given the dispersal of stock ownership in most corporations, there are many others who can. For most stockholders of publicly traded corporations, the existence of the market for shares provides them with an easy exit option, and thus places them at Node A on Williamson's schema. See Weiss, 34 Bus. Lawyer at 58284 (cited in note 325) (stockholders who are displeased with management are more likely to opt for exit rather than choosing to participate in corporate governance).

${ }^{359}$ An internal labor market is a personnel system committed to promotion from within, along internal job ladders, with limited ports of entry other than at the bottom. See Peter B. Doeringer and Michael J. Piore, Internal Labor Markets and Manpower Analysis (1970). Seniority systems also diminish opportunities for horizontal movement between establishments for most unionized employees. 
degrees, for their longevity. On the other hand, their capital in the labor market diminishes. They get older. Their energies, skills, and flexibility for new tasks either diminish or are perceived as diminishing. In short, they become less desirable, less employable. For all of these reasons, the investment of workers is neither general nor easily transferrable.

While Williamson is thus correct that workers are not Node A investors, he incorrectly places them at Node C. He bases his argument that they have adequate alternative bilateral governance mechanisms on a misunderstanding of the law and practice of collective bargaining. He focuses on the ideology and rhetoric of industrial pluralism and its promise to create a privatized mini-democracy within the workplace, but ignores the fact that this promise has never materialized. One of the limitations of this description of the industrial world is that the boundaries of the posited mini-democracy-between areas where unions have input and areas where management has ability to act unilaterally-was never well defined. ${ }^{300}$ The mini-democracy never embraced all decisions of importance to unions. For example, it never extended to basic investment decisions that were said to go to the "core of entrepreneurial control." 361

In recent years the realm of the mini-democracy has been circumscribed even further, as I demonstrated in Part II, above. Williamson does not recognize the degree to which the privatized system of collective bargaining that has emerged under the NLRA fails to protect labor from the adverse consequences of corporate decisions, especially decisions that involve major investments or transformations in corporate form-decisions of the sort made by boards of directors. Furthermore, he fails to recognize that labor is in fact demanding increased participation. These demands for increased participation themselves demonstrate that the bilateral arrangements heretofore in place are no longer satisfactory, at least from labor's point of view. Therefore, Williamson's conclusion that labor enjoys an adequate alternative bilateral governance structure is extremely problematic.

If the current system of collective bargaining is not an adequate bilateral scheme to protect the asset-specific investments of workers, then by Williamson's criteria there is a compelling case

${ }^{360}$ Stone, 90 Yale L.J. at 1557-1559 (cited in note 33); Stone, 45 Md.L.Rev. at 981 (cited in note 33).

381 Fibreboard Paper Products, 379 U.S. at 223 (Stewart concurring). See note 57 and accompanying text. 
for expanded labor participation on corporate boards. The specificity of workers' investments in their companies-that is, their vulnerability to poor management or adverse corporate decisions-combined with their lack of adequate bilateral governance mechanisms, makes them natural candidates for a strong role on the board.

Williamson's argument is market-based and efficiency-driven. He says that groups with asset-specific investments which lack bilateral safeguards should be on the board of directors, not because it is fair, but because without board representation they will not make those investments. That is, he claims that board representation, or some other protective mechanism, serves as an inducement to obtain the investment which otherwise would not be made, or at least not made without a premium price. The argument, then, for shareholder participation on the board is ultimately an empirical claim that if shareholders do not have the protective mechanism of such participation, they will not invest. They will effectively go on strike.

If Williamson's assumptions about shareholder behavior are correct, then there is a strong case for shareholder participation on the board. ${ }^{362}$ However, whether it is stronger than that for participation by other groups, most particularly by employees, is still an open question. One could interpret the recent wave of union demands for participation as a statement by employees that they will not continue to invest their labor without better protections than they now have. One could debate the relative power of the two groups, as expressed by the ability of each to withhold its investment. But this debate is not really relevant. Once we recognize that labor has a legitimate claim to board representation, then how

${ }^{362}$ There is evidence that casts doubt upon the empirical underpinnings of Williamson's analysis. See, e.g., Elliott J. Weiss and Lawrence J. White, Of Econometrics and Indeterminacy: A Study of Investors' Reactions to "Changes" in Corporate Law, 75 Calif.L.Rev. 551, 579-87 (1987) (study showing no statistically significant shareholder reaction to changes in rules of corporate governance under Delaware law); Peter Dodd and Richard Leftwich, The Market for Corporate Charters: "Unhealthy Competition" versus Federal Regulation, 53 J.Bus. 259, 277 (1980) (finding no statistically significant market reaction to decisions by firms to reincorporate in Delaware). See also Fischel, 35 Vand.L.Rev. at 1274-78 (cited in note 335 ) (shareholders are not particularly concerned to have a voice in running a corporation because they can protect themselves by their ability to sell). But see Barry D. Baysinger and Henry N. Butler, The Role of Corporate Law in the Theory of the Firm, 28 J.L. \& Econ. 179, 184-88 (1985) (finding relationship between structure of share ownership and choice of state of incorporation). Furthermore, investor reaction to the issuance of nonvoting classes of stock indicates that stockholders place a premium on holding stock that carries a voice in governance. Overall, the evidence suggests that stockholders assign market value to governance structures in some contexts but not in others. 
much representation it has in relation to the representation claims of other constituent groups within the corporation is a matter of power, negotiation, and contracting. ${ }^{363}$

Indeed, while neither conventional labor nor corporate law has adopted the concept that union officers can contend, negotiate, and compete with other constituent groups about issues of important corporate policy, this concept has become a reality in some other areas of labor-management life. For example, in Chapter 11 reorganization proceedings under the Bankruptcy Act, unions frequently occupy positions on committees of unsecured creditors. On the committees, they negotiate with other groups, particularly major lenders, shareholder representatives, and incumbent management, to determine the future shape and fate of the enterprise. Unions debate every aspect of the company's future, from plant location and choice of product to production methods, management personnel, and financial structure. In this process, unions and the other groups literally renegotiate the nexus of contracts that comprise the corporation. As a result, the corporation as black box becomes disaggregated, and the role and interest of each constituent group becomes transparently clear. The union's role, like that of all the others, is determined by its power in relation to the other power groups. ${ }^{364}$

A similar development has occurred in airline industry take-

ses If we were interested in comparing the power of labor with that of stockholders to withhold its investment, we would see that, at least for labor, the power to withhold labor power and the consequences of withholding it are entirely a function of the legal regulation of labor. The power to withhold labor-to go on strike-depends to a large extent upon whether secondary boycotts are permitted, whether the employer can hire replacements, the rules governing picketing, and so forth. These are the power broker aspects of legal regulation discussed in Part II.

ses In a bankruptcy proceeding, a union has three different types of power. First, it usually represents a large amount of debt-debts the corporation owes to the union membership, to the union itself, and to the various pension and health and welfare funds. This debt gives the union power to affect the reorganization proceeding to the extent of the statutory priorities for wages and pensions. Second, a union has power to affect the reorganization process by virtue of any existing collective bargaining agreements which determine the entity's ongoing labor costs, both during the reorganization and thereafter. This power can be modified to the extent that the Bankruptcy Act permits a debtor in possession to repudiate its existing collective bargaining agreements. See Bankruptcy Code, \$1113, 11 U.S.C. $\S 1113$ (1984); NLRB v. Bildisco \& Bildisco, 465 U.S. 513 (1984). Third, a union has power to affect reorganization to the extent that, even without a collective bargaining agreement, it can compel the reorganized corporation to give its members favorable terms and conditions of employment into the future. This power is determined by the way the bankruptcy and labor laws treat the exercise of labor's economic weapons, and by the extent to which such laws impose on management post-bankruptcy duties to recognize and bargain with the union. 
over battles, where corporate raiders and greenmailers seek the support of incumbent unions to oust inefficient management and avoid bankruptcy filings. In recent years, unions have played decisive roles in several highly publicized contests for control, demonstrating their clout in negotiations with creditors, raiders, white knights, and incumbent managements. Here, as in the bankruptcy setting, unions are one party among several, contracting with the others about their role in the corporation. As Williamson would predict, the asset-specificity of the union members' investment, combined with their lack of other adequate alternative bilateral safeguards, gives them a powerful incentive to seek to shape major corporate decisions.

Williamson's model of corporate governance, in which governance roles are determined by the types of investments and safeguards of each constituency, can illuminate these new developments in labor participation, and can help us reconceptualize a new role for labor in corporate decision making. By making the corporate black box transparent, it becomes possible to consider a more expansive role for labor and to transcend the restrictive categories embedded in labor law doctrine. However, before we wholeheartedly embrace Williamson's approach to corporate governance, or the nexus of contracts view of the firm from which it is derived, another issue needs to be considered. This is the issue of market rationality versus regulation as the dominant mode for organizing labor relations. This issue cuts to the heart of any effort to reconceptualize new roles for labor in the corporation, and I turn to it now.

\section{Re-Conceptualizing the Role of Labor IN THE CoRporate Structure}

In order to reconceptualize the role of labor in the corporation, several issues remain to be addressed. First, there is the question whether society should take a regulatory or a market approach to labor relations and labor participation. The Williamson nexus of contracts view of corporate governance is part of a larger view which says that markets and markets alone should regulate economic actors. It is a deregulatory, or anti-regulatory, theory in that it purports to describe a set of results which are derived from markets alone and justified on the basis of efficiency. However, this view is inadequate as a basis for a new vision of the possibilities for labor participation because, without regulation, it is difficult if not impossible for workers to constitute themselves as a collective voice and to vie for any participation rights at all. Thus, the anti- 
regulatory underpinnings of Williamson's approach must be challenged.

Second, given the need for regulation of labor relations, the important issue becomes the content of the regulation. Because the regulation required is of the constitutive type, it in turn requires a theory that defines the collective entity but that does not rely on functionalist categories.

Third, the relationship between labor participation and labormanagement cooperation must be considered. Some scholars who write about participation conflate it with labor-management cooperation and say that, with cooperation, labor and management are merged. Other scholars claim that participation is a management strategy to coopt unions and divert them from their real mission of serving the membership. My analysis rejects both of these positions and argues instead that participation and cooperation are two different forms of labor relations which must be kept distinct. Participation is collective bargaining in another form.

\section{A. Market Versus Regulatory Approaches to Labor Relations}

As described in Part IV, Williamson argues that the governance rights of the various corporate actors-capital, customers, labor, management, suppliers-can be derived from an analysis of each groups' incentive to seek a role in governance and its power to compel others to grant it such a role. He concludes that stockholders should be the primary decision making force on the board of directors and that labor's participation on the board should be limited to an informational role at most. Williamson claims that these governance arrangements are efficient because they induce the investments necessary to comprise a corporation and because the corporate form benefits society as a whole.

Williamson's theory purports to derive corporate governance structures from a transaction and agency cost analysis rather than from external regulatory intervention. However, there are several problems with this approach, at least when applied to labor. First, one cannot know whether labor can work out adequate "bilateral governance structures" without knowing the power broker rules governing such things as the scope of mandatory bargaining and the realm of permissible contractual protections. That is, the adequacy of collective bargaining to protect workers' asset-specific investments in a firm is a function of the legal rules of collective bargaining.

Second, it is impossible to know labor's "negative market power"-that is, the impact on others if it withheld its invest- 
ment-without knowing the legal rules regulating economic warfare. Whether or not labor would invest in a firm without having a role in governance, and the consequences of its refusal to invest, is a function of the particular rules regulating strikes, boycotts, picketing, and so forth. Because power to withhold one's investment plays a prominent role in Williamson's theory, there can be no efficiency-derived assignment of governance rights that does not rest on a particular regime of legal regulation.

Third, and most important for present purposes, the Williamson view assumes that labor is constituted as a collective entity, capable of defending workers' asset-specific investments either by contending for a role in corporate governance or by negotiating separate bilateral safeguards. However, without a regulatory structure that protects group formation, this is unlikely to occur. In order to obtain a voice in corporate decision making, unions need the group-empowering features of the labor laws-the protection of the rights to form unions and to act collectively that the labor laws embody. Thus, for there to be a group called "organized labor," there must be regulation. ${ }^{365}$ In fact, there must be a regulatory structure akin to the constitutive aspects of the labor laws, which enable and protect group formation, as a necessary precondition for successful participation. ${ }^{386}$

\section{B. Subjective versus Objective Definitions of Labor and Management}

If it is true that the constitutive features of labor regulation are necessary for the attainment of labor participation in management, then the categories of "management" and "labor" must be redefined in a way that reinforces the statutory purpose of ena-

${ }^{385}$ Of course there were unions organized before the NLRA was enacted and before unions were granted legal personality. However, it was the protection of the right to organize by the National Industrial Recovery Act in 1932 and later by the NLRA that lead to the largest growth of union organizing in American history. See Irving Bernstein, Turbulent Years: A History of the American Worker 1933-1941 37 (1970). See also Paul Weiler, Promises to Keep, 96 Harv.L.Rev. 1769 1776-81 (1983) (correlating current decline in union organizing success with nonenforcement of the labor laws).

s6s In Part I, I distinguished two aspects of the labor laws, which I designated the "constitutive features" and the "power broker features." The power broker features of the labor laws as well as the constitutive features affect the ability of unions to claim participatory rights. As Part II demonstrated, the current power broker doctrines are unfavorable but not immutable. However, if there were favorable power broker doctrines in current usage, then paradoxically, unions would both be empowered in the struggle for participation, and would at the same time, need participation less. They could protect their interests through more conventional forms of bargaining. 
bling and constituting labor as a collectivity. The constitutive aspects of the NLRA protect the formation and integrity of the entity known as organized labor, in part by ensuring and policing the boundaries of the labor collectivity from intrusion by management. Insofar as the integrity of the collective entity depends upon its autonomy from management, there must be a boundary between labor and management. However, for reasons stated above, management and labor and the boundaries that separate them should not be defined functionally. Thus, some better definition must be found.

Any effort to redefine the boundary between management and labor so as to facilitate participation cannot ignore the role of power and coercion in the workplace. ${ }^{367}$ Management's power to hire, fire, set working conditions, determine compensation levels, and so forth, means that labor and management cannot truly be partners in production. Furthermore, labor and management cannot be treated as equivalent institutions with symmetrical powers and possibilities. As the sociologist Charles Lindblom has said:

One of the conventional insensitivities of contemporary social science is revealed in scholarly works on interest groups. By some unthinking habit, many such works treat all interest groups as though on the same plane, and, in particular, they treat labor, business, and farm groups as though operating at some parity with each other. ${ }^{368}$

One crucial difference between management and labor is that they take different collective forms and do so for different reasons. As Claus Offe has noted, labor as a category does not exist until capital has brought individual employees together into a "workforce," whereas capital is aggregated into the corporate form by definition. ${ }^{368}$ Furthermore, organized labor only comes into existence to the extent that disparate individuals organize voluntarily into a collectivity that comprises substantially all of a given workforce. ${ }^{370}$ To do this, they need a collective consciousness. They must forge a group identity that merges rather than aggregates the

${ }^{387}$ See Michael Poole, Workers' Participation in Industry 23-24 (1975) (workers' control, participation, and cooperation implicate questions of power in industry and in society). ${ }^{368}$ Charles E. Lindblom, Politics and Markets 193 (1977). Similarly, Claus Offe has called efforts to equate labor and management the " 'liberal error' of 'false identity" " which "obscur[es] the category of social class." Claus Offe, Two Logics of Collective Action, in Claus Offe, Disorganized Capitalism 170, 173-74 (1985).

s8s Offe, Two Logics of Collective Action at 176.

${ }^{370} \mathrm{Id}$. at $178-79$. 
separate parts. ${ }^{371}$ Thus, Offe argues, for workers to organize is a very different type of undertaking than it is for capitalists to organize. For workers to organize themselves into a collectivity, their "logic of collective action" requires that they develop an ideology-a shared vision of the collectivity that transcends the individual's need or greed and that posits a higher altruistic goal. As he notes, "[o]nly to the extent that associations of the relatively powerless succeed in the formation of a collective identity ... can they hope to change the original power relation." ity of labor cannot be defined simply on the basis of aggregate selfinterest. . $^{373}$

In their collective form, then, labor and corporations are very different. For corporations, the profit motive tends to provide a sufficient basis to bring the group together and to achieve each one's goal of profitable investment. Thus for most purposes, the corporate collectivity is adequately described as discrete contractual relations between self-interested individuals. For labor, on the other hand, market forces alone do not automatically produce a conjoining of individuals into a collective form. Further, union formation gives rise to numerous collective action problems and free rider effects that do not arise in the formation of the corporate collectivity. ${ }^{374}$ As noted above, for labor to achieve a collective form, a collective ideology must be articulated, and the assistance of positive law is frequently required as well. Consequently, while the collectivity of labor is contractual in some respects, it is better described as an entity.

The significance of this observation is that while I have argued we should disaggregate the corporate black box, it is altogether appropriate to treat a union as a black box for purposes of defining the group. Unions typically are made up of many different types of

371 Id. at 183.

372 Id.

s73 Similarly, Barrington Moore, Jr., in Injustice: The Social Bases of Obedience and Revolt 88 (1978), writes:

[A]ny political movement against oppression has to develop a new diagnosis and remedy for existing forms of suffering, a diagnosis and remedy by which this suffering stands morally condemned. These new moral standards of condemnation constitute the core identity of any oppositional movement.

As part of this new identity based on a new perception of evil there develops a new definition of friend and foe.

While Moore was referring to political movements to change existing power relations, the same can be said of a union organizational drive, which attempts to change power relations within a workplace or firm.

s74 Mancur Olson, The Logic of Collective Action: Public Goods and the Theory of Groups (1968). 
people who share some goals, yet have others that diverge. ${ }^{375}$ Yet, if it is true that the collectivity can only exist to the extent that it can formulate a collective identity, then such differences must be submerged. ${ }^{376} \mathrm{~A}$ union must therefore be defined and constituted on the basis of an objective definition of the collectivity, not on the basis of individual workers' subjective preferences. ${ }^{377}$

The task for labor law and labor theory, then, is to develop an objective definition of labor and management that has enough correspondence to employee subjective perception to permit the formation of a collective identity. Functionalism attempted a definition but it was inadequate because it froze each group into a circumscribed social role and reinforced preexisting power relations. A better definition can be found in the concept of "interest,"

s75 For example, older workers have different priorities than younger ones in terms of preferences for pensions instead of wages, and in terms of controlling the pace and intensity of work. Similarly, minority workers often have interests different from white workers, and women workers have different needs and goals from men. The labor laws do not permit separate bargaining or representation on the basis of these differences. See, e.g., Emporium Capwell Co. v. Western Addition Org., 420 U.S. 50 (1975) (minority workers who attempted to negotiate directly with the employer in support of anti-discrimination demands without going through the union grievance procedure had engaged in unprotected activity).

${ }^{376}$ J.I. Case Co. v. Labor Board, 321 U.S. 332, 338 (1944) ("The practice and philosophy of collective bargaining looks with suspicion on individual advantages"). This is not to say that individuated differences can form the basis of discriminatory action within the union. The duty of fair representation remains available to police union action which unfairly or discriminatorily disadvantages one group within the union. See, e.g., Steele v. L. \& N. R. Co., 323 U.S. 192, 202-03 (1944) (union violated its duty of fair representation when it negotiated promotion and transfer scheme that was racially discriminatory); Retana v. Apartment, Motel, Hotel \& El. Op. U., Loc. No. 141, 453 F.2d 1018, 1024 (9th Cir. 1972) (union may violate duty of fair representation when it fails to print bilingual materials for its members who do not speak English). The argument here is merely that such differences cannot serve as the basis of the definition of the union.

${ }^{377}$ Further, to rely on individual choice alone is to deny that management has the power to affect workers' preferences, or at least the articulation of those preferences. This power is reflected in many NLRB doctrines about union elections. The NLRB has long recognized that in the workplace, subtle and blatant coercion operate to make "free choice" implausible except under highly controlled and regulated circumstances. See, e.g., General Shoe Corporation, 77 N.L.R.B. 124, 127 (1948) (announcing "laboratory conditions" standard for union election campaigns); Dal-Tex Optical Company, Inc. 137 N.L.R.B. 1782, 1786-1787 (1962) (finding employer speech coercive). At the present time, the NLRB has weakened its approach to regulation of election conduct, and has softened its approach to the problem of coercion. See, e.g., Midland National Life Insurance Co., 263 N.L.R.B. 127, 133 (1982) (announcing that the NLRB will no longer intervene in an election on the basis of misleading campaign statements). However, the past doctrine is relevant for showing that at times in its history, the NLRB has recognized the concept of "free choice" has limited usefulness in the workplace setting, where there is unequal power and almost limitless possibilities for coercion. See Labor Board v. Parts Co., 375 U.S. 405, 409 (1964) (employer conduct favorable to employees in the midst of an election campaign impinges upon their freedom of choice). 
which has the advantage of being an objective term, yet not one wholly divorced from the subjective experience of the social actors, nor one that merely reinstates the status quo. The concept of "interest" appears frequently in sociological descriptions of social life. For example, Anthony Giddens says,

It is precisely the concept of interest that is most immediately linked to those of conflict and solidarity . . . . The concept of interest has to be understood as a metatheoretical one. ${ }^{378}$

Giddens argues for a concept of interest that is neither strictly needs-based nor uniquely class-based. Yet on the other hand, he rejects the amorphous concept of interest embodied in interestgroup pluralism. Rather, Giddens claims, "interest" is linked to conflict and power, and that, indeed, society is defined as "a system of power founded in entrenched divergencies of interest." Thus while Giddens does not tell us what "interest" is, he tells us that defining "interest" is the key to understanding and organizing conflict between social groups.

The concept of interest has also been used to define management-labor boundaries in a number of contexts that have already been discussed. For example, it lies at the core of the Williamson nexus of contracts approach to corporate governance, which categorizes the various groups in the corporation on the basis of a typology of interests. Similarly, in Chapter 11 bankruptcy proceedings, groups are organized and represented for participation purposes by interest. ${ }^{\mathbf{3 8 0}}$

If one opts for an interest-based category of labor, the next problem is to define what labor's interests are. Various theorists have attempted to articulate labor's interests for over a hundred years. For example, Karl Marx posited that workers have an interest in being paid the full value of their labor power, rather than having "surplus value" extracted. ${ }^{381}$ Selig Perlman argued that workers' primary interest is job security and expanded job oppor-

${ }^{378}$ Giddens, Studies in Social and Political Theory at 348 (cited in note 318).

370 Id. at 347.

${ }^{380}$ See, e.g., 11 U.S.C. \$1122(a) (creditors to be classified in terms of "claims or interests"); 11 U.S.C $\$ 1123$ (a)(4) (requiring that plans "provide for the same treatment for each claim or interest of a particular class"). Furthermore, the Chapter 11 procedures suggest that the phrase refers to objectively defined interests, defined primarily by the priority scheme found in the Code itself. See, e.g., the "absolute priority rule" of 11 U.S.C. \$1129(b), activating a "cram down" on the basis of the priorities for unsecured claims set forth in 11 U.S.C. $\$ 507$.

${ }^{383}$ Karl Marx, Value, Price and Profit 37-43, in Karl Marx, Labour and Capital \& Value, Price and Profit (1976 Comb'd ed.). 
tunities. ${ }^{382}$ Others have written about workers' interests in such intangibles as self-actualization, creativity, and dignity. ${ }^{383}$ Still others have argued that workers' interests are found in the absence of hierarchical control and arbitrary power. ${ }^{384}$ All these ideas are possible formulations of labor's interests, and all are linked to particular historical periods. ${ }^{385}$ The task of labor law scholars today is to articulate a conception of labor's interests that is appropriate to our time. Only with such a theory can labor law doctrine be reshaped to accommodate labor participation in corporate decision making and the power shifts that participation entails.

\section{Participation in Decision Making versus Labor-Management Cooperation}

Having rejected the functionalist categories of "labor" and "management" in favor of interest-based categories, it becomes necessary to consider whether, or to what extent, the interests of labor and those of other groups in the corporate structure coincide. Some claim that participation makes the interests of labor and management not only compatible, but entirely congruent. Of those who make this claim, some have embraced participation as signifying a new era of labor-management cooperation, ${ }^{386}$ while others have attacked it as a new form of cooptation. ${ }^{387}$ The cooptation

s82 Selig Perlman, A Theory of the Labor Movement 272-79 (1948 ed.) (originally published 1928).

sss See, e.g., Michael Burawoy, Manufacturing Consent (1979) (workers' interest in dignity); Tom Juravich, Chaos on the Shop Floor 148-50 (1985) (workers' interest in decision making about their work).

s84 See, e.g., Samuel Bowles and Herbert Gintis, Democracy and Capitalism: Property, Community, and the Contradictions of Modern Social Thought (1986).

s8s Barrington Moore, Jr. writes about the historical variability of a group's identity and its ability to articulate a basis of solidarity and engage in collective action in Moore, Injustice at $460-462$ (cited in note 374 ).

${ }^{386}$ For example, the interim report by the Department of Labor on U.S. Labor Law and the Future of Labor-Management Cooperation is primarily devoted to employee involvement programs and labor-management problem-solving committees, applauding such "joint participation [as] the hallmark of contemporary labor-management cooperation." BLMR Rept. No. 1113 at 65 (Feb. 1987). See also McCormick, 15 U.Mich.J.L.Ref. at 258 (cited in note 29) (union officer on Chrysler board of directors is an "experiment with non-adversarial labor relations."); Moberly, 15 Stetson L.Rev. at 113 (cited in note 22) (equating worker participation with labor-management cooperation).

${ }^{\text {s87 }}$ See, e.g., Kohler, 27 B.C.L.Rev. at 517 (cited in note 28) (participation is an integrative scheme that aims to convince workers to adopt management's goals); Robert Howard, Brave New Workplace: The Reenchantment of the Workplace 123-29 (1985) (describing participatory management theories in practice and criticizing them for advocating that managers give their subordinates the illusion that they have input into important decisions when in actuality they do not). 
argument says that, under the pretext of shared power, participation induces unions to adopt management's point of view and to act to further management's interests at the expense of the interests of the workers. Indeed, some have claimed that participation is "one of the last tricks of capitalism: corruption of labor through pseudo-participation." 388

The concept of participation that I advocate is neither cooperative nor cooptive. Rather, it is participation within a conflictbased model of corporate governance, in which labor bargains and contends with others for a role in decision making. The actual experience of participation supports this view. Most accounts of labor participation show that it is just as adversarial as traditional collective bargaining. ${ }^{38 \theta}$

For example, union participation in Chapter 11 bankruptcies has lead to heated and bitter battles over such issues as whether the company (the debtor-in-possession) can reject its collective bargaining agreements and thereby unilaterally reduce wages, ignore seniority in setting new working conditions, ${ }^{390}$ and terminate health and pension benefits. ${ }^{381}$ These are the issues over which unions fight to the death. Even in less acrimonious proceedings, unions representing a large number of employee-creditors, many of whom have unpaid wage or benefit claims, compete with other creditors for a portion of the estate. ${ }^{392}$ The ensuing triangular in-

${ }^{388}$ See Frank Deppe, et al., Kritik der Mitbestimmung. Partnerschaft oder Klassenkampf? (1969), paraphrased and translated by Gunther Teubner, Industrial Democracy Through Law: Social Functions of Law in Institutional Innovations, in Terrence Daintith and Gunther Teubner, Contract and Organization: Legal Analysis in the Light of Economic and Social Theory 261, 268 (1986).

389 See, Simon, Labor at the Crossroads-A Response, in Morris, ed., American Labor Policy at 311-312 (cited in note 26) (unions must use stock ownership, takeover battles, and corporate campaigns to achieve their goals because the labor law has been weakened).

${ }^{390}$ See, e.g., Truck Drivers Local 807 v. Carey Transp. Inc., 816 F.2d 82, 86 (2d Cir. 1987) (dispute about employer-debtor effort to reduce wages, benefits, and work assignment rules in Chapter 11 proceeding); Wheeling-Pittsburg Steel v. United Steelworkers, 791 F.2d 1074 (3rd Cir. 1986) (dispute over employer effort to reduce wages, extend contract, and reduce and/or eliminate benefits in Chapter 11 proceeding). See generally 11 U.S.C. \$1113 (1984) (amending Bankruptcy Code to provide procedures for employer-debtors seeking to reject collective bargaining agreements).

${ }^{391}$ See In Re Braniff Airways, Inc. 22 Bankr. 1001 (N.D.Tex. 1982) (approving employer-debtor attempts to reduce pension benefits in bankruptcy proceeding); Jones \& Laughlin Hourly Pension Plan, 824 F.2d 197, 201-02 (2d Cir. 1987) (workers aggrieved by an employer-debtor's termination of their pension plans should file their claims in the bankruptcy court).

${ }^{392}$ See Marcus, Richards, and Korman, Labor Representation on the Committee of Unsecured Creditors (cited in note 16), for a discussion of union representation of unpaid wage and pension claims of union members during bankruptcy proceedings. 
teraction among the union as creditor, the other creditors, and the company as debtor-in-possession is a complex and intense form of collective bargaining.

Similarly, the press is filled with accounts of labor-management conflict transposed to the arena of corporate takeover battles. ${ }^{393}$ Union members of boards of directors are also beginning to bring traditional collective bargaining concerns into the boardroom. ${ }^{394}$ As union board membership increases, more traditional labor-management issues will be determined in the boardroom, and boardroom conflict will increase as well. ${ }^{395}$

Indeed, I would contend that labor-management cooperation is more an ideology than a meaningful description of employee participation. It is an ideology that evokes a vision of the good-a world where labor and management work together to improve productivity, restore American competitiveness, and increase social wealth, all the while sharing the bounty fairly and equitably. ${ }^{386}$ While this vision is appealing and inspiring, its relationship to worker participation is heuristic at best. ${ }^{397}$

s9s See generally Adam Bernstein, Move Over Boone, Carl, and Irv-Here Comes Labor, Business Week 124 (Dec. 14, 1987) (describing union involvement in hostile buyouts and mergers). In addition, unions are negotiating with corporate raiders to oust incumbent managements. For example, the unions representing the pilots, machinists, and flight attendants in Pan American Airways recently negotiated a contingent labor contract with some members of management in which they will agree to concessions in exchange for the ouster of the current chairman of the board. Pan Am and the Rise of Union Power, New York Times D1, col.1 (Jan. 25, 1988). The International Association of Machinists attempted to force a similar bargain in Eastern Airlines in the winter of 1986. See William Serrin, Unionist Says Eastern Acted to Shield Borman, New York Times D5, col.1 (Feb. 27, 1986). Also in 1986, the pilots union at United Airlines played a central role in blocking the efforts of that airline to acquire Frontier Airlines. See Salpukas, New York Times D1, col. 6 (Aug. 29, 1986) (cited in note 22). Such union tactics are increasing, as unions become knowledgeable about corporate takeover strategies and see in them the potential to protect their memberships.

sas See John Hoerr, Blue Collars in the Boardroom: Putting Business First, Business Week 126, 128 (Dec. 14, 1987) (conflicts between union and management board members in Hyatt Clark Industries).

${ }^{395}$ Some union directors are of the opinion that they should absent themselves from any boardroom discussions where business relevant to the union is discussed. See Carver, 1983 U.Ill.L.Rev. at 686-687 (cited in note 26) (labor members of boards of directors should not participate in deliberations about collective bargaining strategy and should be denied access to such information). My analysis in Part IV suggests a different interpretation of the role of a union board member.

${ }^{396}$ See Robert A. Dahl, A Preface to Economic Democracy 107-110 (1985) (describing beneficial effects of "self-governing enterprises").

397 The one area where the legal system is relaxing some of the boundaries between labor and management is in the employee involvement context. See Hertzka \& Knowles, 503 F.2d 625 (cited in note 380), Chicago Rawhide Mfg. Co. v. National Labor Rel. Bd., 221 F.2d 165 (9th Cir. 1955). Commentators have differed as to whether this is a harbinger of more 
To argue that participation can be something other than a false promise, however, it is necessary to argue that there is a real possibility of redistributing power within the firm to the benefit of workers in both the long and short run. If the fate of the firm is totally controlled by the various markets in which it operates-the product market, the factor market, the market for managerial talent, and the market for corporate control-then participation creates only an illusion of power, not power itself. In this case, the cooptation view has great force.

The German social theorist, Gunther Teubner, has analyzed this question from the point of view of German co-determination law, and has concluded that the effect of co-determination and participation on the power and integrity of unions is indeterminate. He writes:

If the relations between market and organization are defined by conditions of perfect competition, co-determination does not matter. Under perfect competition the constraints of the market on the organization are so strong that there is only one best solution. However, under conditions of market-imperfections-concentration, oligopolization-those constraints become weaker and management gains a considerable discretionary power in its decisions ..... And precisely this discretionary power is the main target of codetermination .....398

That is, since no market displays perfect competition, all management has at least some discretion. Co-determination or participation can affect how that discretion is exercised. On the issue of cooptation, Teubner goes on to say:

[L]abor gets "corrupted" insofar as labor representatives have to bend to economic constraints, but this is only true for decisions outside the [realm] of discretion. Insofar as management has gained discretionary power, labor with a strong formalized position within the enterprise possesses the power to make

cooperative industrial relations, or a return to the company union. Compare, Stanley J. Brown and Jay L. Birnbaum, Employee Committees and the N.L.R.A., 13 Empl.Rel.L.J. 61, 62 (1987) ("Legitimate employee committees should not be constrained by a model of adversary labor relations that was perhaps valid in the early days of the Act, but is now outmoded") with Note, Collective Bargaining as an Industrial System: An Argument Against Judicial Revision of Section 8(a)(2), 96 Harv.L.Rev. 1662, 1678-1680 (1983) $(\S 8(a)(2)$ continues to play important function in our system of labor regulation).

${ }^{398}$ Gunther Teubner, Industrial Democracy Through Law?, in Daintith and Teubner, eds., Contract and Organization at 268-69 (cited in note 388). 
"non-corrupted" demands for the workers' interest.

Participation, then, offers labor the possibility of sharing in discretionary power and capturing some of its benefits for its members.

Teubner's analysis has ramifications for labor participation in the United States. The most heavily unionized industries in the United States tend to be oligopolies, ${ }^{400}$ which, in his typology, are firms where management has discretion. Management discretion has many outlets, including discretion to determine the division of revenues between profits and wages, the methods of production, and, in the face of economic difficulties, whether to modernize, merge, or disinvest. These are the types of decisions which have a significant impact on union members, and which unions therefore seek to affect. The inability of unions to affect these decisions under conventional labor law has given rise to the current wave of demands for union participation. Thus, as Teubner suggests, to the extent that such decisions are made by a management which has discretion, they are decisions in which unions can benefit from participation. Ironically, only by participation can unions know what are the contours of discretion at any point in time. Participation thus has the potential of putting more issues up for grabs in the labor-management conflict, but it carries the risk that for any given issue, labor participation may not improve the outcome. However, because the area of discretion is potentially wide, the spoils are worthy of the fight.

\section{CONCLUSION}

In this piece, I have tried to delineate the doctrinal conflicts between labor law and the emerging forms of labor participation. I have tried to demonstrate that the doctrinal conflicts do not mean that labor law must be completely abandoned to make room for participation. Rather, I have argued that participation can be accommodated within the existing legal framework governing collective bargaining if the NLRB's and the courts' narrow conceptions of labor, management, and the corporation are discarded. I have also argued that the constitutive features of the labor laws, which protect union formation and union autonomy, are the necessary preconditions for any genuine form of union power. At the same time, however, I have not presented a detailed blueprint for the reconceptualization of the boundaries between labor and manage-

399 Id. at 269.

100 Freeman \& Medoff, What Do Unions Do? at 32 (cited in note 42). 
ment, nor a recipe for labor law reform. Rather, I have sketched out the relevant issues, and pointed in the direction of future work. After all, the challenge posed by the new union demands for participation is to break free of the restrictive legal and scholarly categories of the past so as to construct new and better ground rules for labor-management relations. Here, I have tried to take the first step. 